\title{
Constraining homo- and hetero-anion dimers in ultra-close proximity within a self-assembled hexacationic cage
}

\author{
Hongye Wang, ${ }^{a}$ Shuai Fang, ${ }^{a}$ Guangcheng Wu, ${ }^{a}$ Ye Lei, ${ }^{a}$ Qiong Chen, ${ }^{a}$ Hongliang Wang, ${ }^{a}$ Yating Wu, ${ }^{a}$ Chuhao Lin, ${ }^{a}$ Xin Hong, ${ }^{a}$ \\ Sung Kuk Kim, ${ }^{\mathrm{c} J o n a t h a n ~ L . ~ S e s s l e r ~}{ }^{\mathrm{b}}$ and Hao Li ${ }^{\mathrm{a}, *}$ \\ aDepartment of Chemistry, Zhejiang University, Hangzhou 310027, China; E-mail: lihao2015@zju.edu.cn

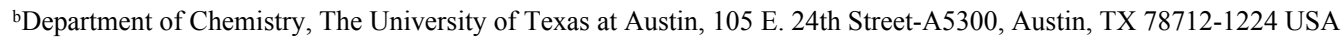 \\ 'Department of Chemistry, Research Institute of Natural Science, Gyeongsang National University, Jinju, 660-701, Korea.
}

\section{Supporting Information}

\section{Table of contents}

1. Materials and general methods ..........................................

2. Synthetic procedures …................................................

3. NMR spectra and HRMS spectra ......................................6

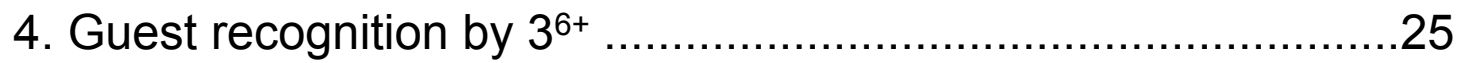

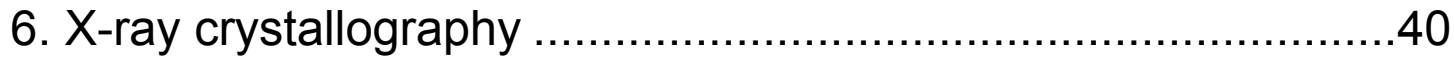

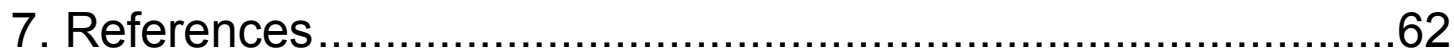




\section{Materials and general methods}

All reagents and solvents were purchased from commercial sources and used without further purification. Manipulations were performed under a normal atmosphere unless otherwise indicated. Nuclear magnetic resonance (NMR) spectra were recorded at ambient temperature using Bruker AVANCE III 400/500 and Agilent DD2 600 spectrometers, with working frequencies of $400 / 500 / 600$ and $100 / 125 / 150 \mathrm{MHz}$ for ${ }^{1} \mathrm{H}$ and ${ }^{13} \mathrm{C}$, respectively. Chemical shifts are reported in ppm relative to the residual internal non-deuterated solvent signals ( $\mathrm{D}_{2} \mathrm{O}: \delta=4.79 \mathrm{ppm}, \mathrm{DMSO}-d_{6}: \delta=2.50 \mathrm{ppm}, \mathrm{CD}_{3} \mathrm{CN}: \delta=$ $1.94 \mathrm{ppm}$ ). High-resolution mass spectra (HRMS) were recorded on a Fourier transform ion cyclotron resonance mass spectrometry (FT-ICR MS). X-ray crystallographic data were collected on a Bruker D8 Venture diffractometer. 


\section{Synthetic procedures}

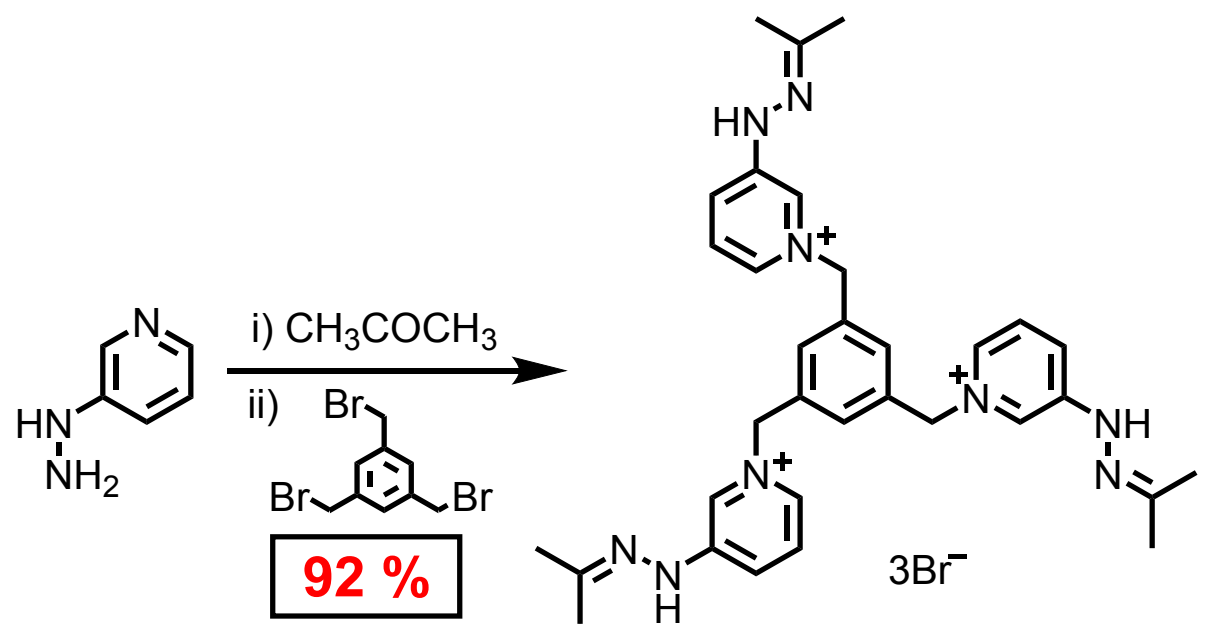

Scheme S1. Synthesis of $1^{3+} \cdot 3 \mathrm{Br}$

$1^{3+} \cdot 3 \mathrm{Br}$ : A solution of 3-hydrazinopyridine $(1.00 \mathrm{~g}, 9.2 \mathrm{mmol})$ in $250 \mathrm{~mL}$ of acetone was heated to reflux for $1 \mathrm{~h} .1,3,5-$ Tri(bromomethyl)benzene (328 $\mathrm{mg}, 0.92 \mathrm{mmol}$ ) was then added to the reaction mixture. The reaction was heated at reflux for another three days. The precipitate obtained in this way was collected via filtration and washed with hot acetone $(3 \times 20 \mathrm{~mL})$, yielding pure $1^{3+} \cdot 3 \mathrm{Br}-(680 \mathrm{mg}, 92 \%)$ as a yellow powder. $1^{3+} \cdot 3 \mathrm{Br}$ was characterized by recording its ${ }^{1} \mathrm{H}$ NMR spectrum (Figure S1), ${ }^{13} \mathrm{C}$ NMR spectrum (Figure S2), HSQC spectrum (Figure S3), HMBC spectrum (Figure S4), as well as by means of mass spectrometry (Figure S5). ${ }^{1} \mathbf{H}$ NMR (400 MHz, DMSO- $\left.d_{6}\right): \delta(p p m): 10.08$ (s, 3H), 8.67(s, 3H), 8.47(d, J = 7.5 Hz, 3H), 8.10(d, J = $11 \mathrm{~Hz}, 3 \mathrm{H}), 7.89(\mathrm{dd}, \mathrm{J}=11 \mathrm{~Hz}, \mathrm{~J}$ $=7.5 \mathrm{~Hz}, 3 \mathrm{H}), 7.60(\mathrm{~s}, 3 \mathrm{H}), 5.84(\mathrm{~s}, 6 \mathrm{H}) 1.990(\mathrm{~d}, \mathrm{~J}=3.5 \mathrm{~Hz}, 18 \mathrm{H}) .{ }^{13} \mathrm{C}$ NMR $(100 \mathrm{MHz}$, DMSO- $\left._{6}\right): \delta(\mathrm{ppm}): 151.33,146.06,136.28,133.50,128.97,128.10,127.34,126.72$ 62.44, 24.92, 17.77. HRMS (ESI): $m / z$ calculated for $\mathrm{C}_{33} \mathrm{H}_{42} \mathrm{~N}_{9}{ }^{3+}[M]^{3+} 188.1182$, found 188.1169; calculated for $\mathrm{C}_{33} \mathrm{H}_{41} \mathrm{~N}_{9}{ }^{2+}[\mathrm{M}-\mathrm{H}]^{2+}$ 281.6737, found 281.6740; calculated for $\mathrm{C}_{33} \mathrm{H}_{42} \mathrm{BrN}_{9}{ }^{2+}[M+\mathrm{Br}]^{2+} 321.6368$, found 321.6375 . 

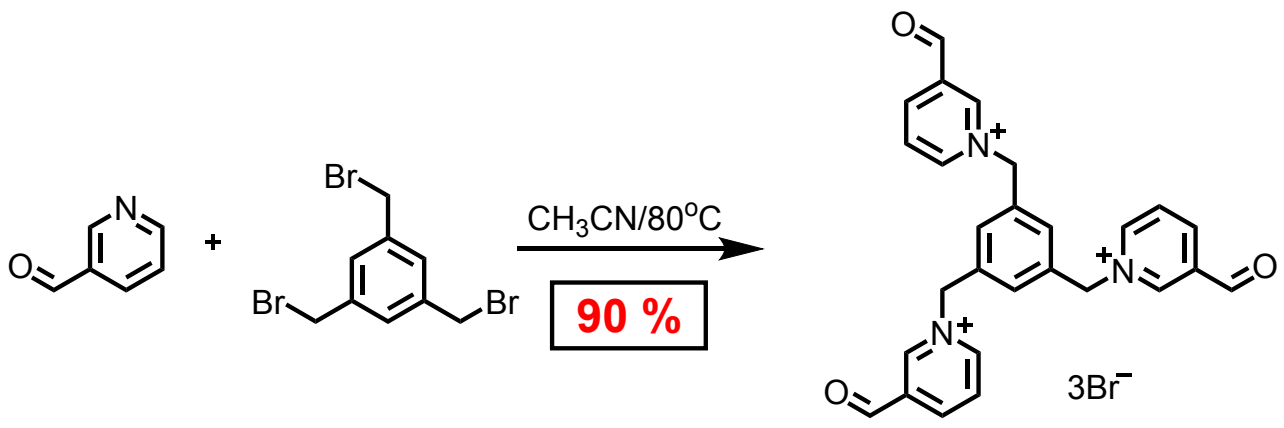

Scheme S2. Synthesis of $2^{3+} \cdot 3 \mathrm{Br}^{-}$.

$2^{3+} \cdot 3 \mathrm{Br}$ : 4-Pyridinecarboxaldehyde $(1.50 \mathrm{~g}, 14 \mathrm{mmol})$ and 1,3,5-tri(bromomethyl) benzene (500 mg, $1.4 \mathrm{mmol}$ ) were dissolved in $100 \mathrm{~mL}$ of acetonitrile and heated at reflux for 48 hours. The resulting precipitate was collected via filtration and washed with hot acetonitrile $(3 \times 20 \mathrm{~mL})$ to give the product $2^{3+\cdot} \cdot 3 \mathrm{Br}^{-}(922 \mathrm{mg}, 90 \%)$ as a white powder. $2^{3+\cdot} \cdot 3 \mathrm{Br}$ - was fully characterized by recording its ${ }^{1} \mathrm{H}$ NMR spectrum (Figure S6), ${ }^{13} \mathrm{C}$ NMR spectrum (Figure S7), HSQC spectrum (Figure S8) and HMBC spectrum (Figure S9), as well as via mass spectrometry (Figure S10). ${ }^{1} \mathrm{H}$ NMR $\left(400 \mathrm{MHz}, \mathrm{D}_{2} \mathrm{O}\right) \delta(\mathrm{ppm}):$ 9.01(s, 3H), 8.89 (d, J = 7.5 Hz, 3H), 8.68 (d, J = $10 \mathrm{~Hz}, 3 \mathrm{H}$ ), 8.13 (dd, J = 7.5 Hz, J = $10 \mathrm{~Hz}, 3 \mathrm{H}$ ), $7.62(\mathrm{~s}, 3 \mathrm{H}), 6.23$ (s, 3H), 5.90 (s, 6H). ${ }^{13} \mathrm{C}$ NMR (100 MHz, $\left.\mathrm{D}_{2} \mathrm{O}\right) \delta$ (ppm): 144.23, 144.16, 143.45, 142.52, 135.48, 130.54, 128.46, 86.62, 63.57. MS (ESI): $\mathrm{m} / \mathrm{z}$ calculated for $\mathrm{C}_{27} \mathrm{H}_{26} \mathrm{~N}_{3} \mathrm{O}_{4}{ }^{3+}\left[M+\mathrm{H}_{2} \mathrm{O}\right]^{3+}$ 152.0636, found 152.1; calculated for $\mathrm{C}_{27} \mathrm{H}_{28} \mathrm{~N}_{3} \mathrm{O}_{5}{ }^{3+}\left[M+2 \mathrm{H}_{2} \mathrm{O}\right]^{3+}$ 158.0671, found158.1; calculated for $\mathrm{C}_{27} \mathrm{H}_{30} \mathrm{~N}_{3} \mathrm{O}_{6}{ }^{3+}\left[M+3 \mathrm{H}_{2} \mathrm{O}\right]^{3+}$ 164.0706, found 164.1. 


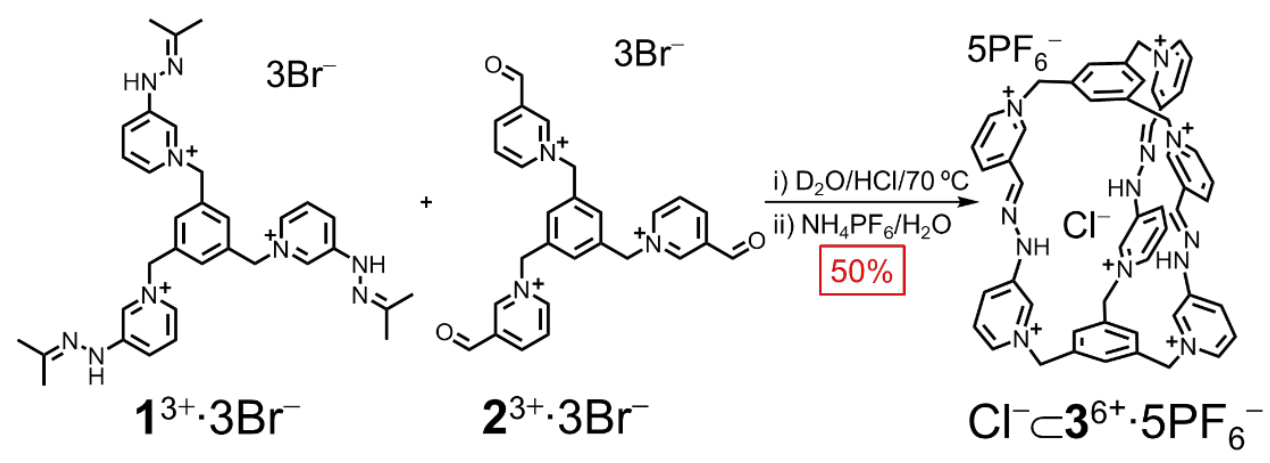

Scheme S3. Synthesis of $\mathrm{Cl}^{-} \subset 3^{6+} \cdot 5 \mathrm{PF}_{6}^{-}$.

$\mathrm{Cl}^{-} \subset \mathbf{3}^{6+} \cdot 5 \mathrm{PF}_{6}{ }^{-}$: Precursors $1^{3+} \cdot 3 \mathrm{Br}-(100 \mathrm{mg}, 0.12 \mathrm{mmol})$ and $\mathbf{2}^{3+} \cdot 3 \mathrm{Br}-(82 \mathrm{mg}, 0.12 \mathrm{mmol})$ were combined in $50 \mathrm{~mL}$ of water. Concentrated $\mathrm{HCl}(1 \mathrm{~mL})$ was then added. The reaction mixture was heated at $70{ }^{\circ} \mathrm{C}$ for $12 \mathrm{~h}$. After cooling, excess of $\mathrm{NH}_{4}^{+} \cdot \mathrm{PF}_{6}-$ was added until no further precipitation was observed. The solid obtained in this way was filtrated and washed with water $(3 \times 10 \mathrm{~mL})$. Chromatographic purification was then performed over silica gel to improve the purity of $3^{6+}$ using a $12: 7: 1$ (by volume) mixture of $\mathrm{NH}_{4}{ }^{+\cdot} \mathrm{Cl}^{-}(2 \mathrm{M}$ in water), $\mathrm{MeOH}$ and $\mathrm{MeNO}_{2}$ as the eluent. The fraction containing $3^{6+}$ was collected and the solvent was evaporated, followed by adding an aqueous solution of $\mathrm{NH}_{4}{ }^{+} \cdot \mathrm{PF}_{6}{ }^{-}$to effect counterion exchange. Under these conditions, the monoanionic complex $\mathrm{Cl}^{-} \subset 3^{6+} \cdot 5 \mathrm{PF}_{6}^{-}$ precipitates out as a yellow solid. $\mathrm{Cl}^{-} \subset 3^{6+} \cdot 5 \mathrm{PF}_{6}{ }^{-}$was collected by filtration (97 mg, $50 \%$ ) and fully characterized by recording its ${ }^{1} \mathrm{H}$ NMR spectrum (Figure S11), ${ }^{13} \mathrm{C}$ NMR spectrum (Figure S12), DEPT-135 spectrum (Figure S13), ${ }^{1} \mathrm{H}-{ }^{1} \mathrm{H}$ COSY spectrum (Figure S14), HSQC spectrum (Figure S15), HMBC spectrum (Figure S16), as well as via mass spectrometry (Figure S17) and single crystal X-ray diffraction analysis (Figure S63).

The semi-pure complex $3^{6+} \cdot 6 \mathrm{PF}_{6}^{-}$was obtained via a second round of counter anion exchange, which was accomplished by adding a $\mathrm{MeCN}$ solution of $\mathrm{Cl}^{-} \subset 3^{6+} \cdot 5 \mathrm{PF}_{6}{ }^{-}$into an aqueous solution of $\mathrm{NH}_{4}+\cdot \mathrm{PF}_{6}{ }^{-}$and collecting the resulting precipitate. The semi-pure cage $3^{6+\cdot} 6 \mathrm{PF}_{6}{ }^{-}$obtained in this way was characterized by recording its ${ }^{1} \mathrm{H}$ NMR spectrum (Figure S18 and Figure 19), ${ }^{1} \mathrm{H}-{ }^{1} \mathrm{H}$ COSY spectrum (Figure S20) and ${ }^{1} \mathrm{H}-{ }^{1} \mathrm{H}$ NOESY spectrum (Figure S21). The ${ }^{1} \mathrm{H}$ NMR spectrum of $3^{6+} \cdot 6 \mathrm{PF}_{6}{ }^{-}$(Figure 18) was revealed peaks corresponding to the presence of a small amount of $\mathrm{Cl}^{-} \subset 3^{6+} \cdot 5 \mathrm{PF}_{6}^{-}$. 
Complex $3^{6+\cdot 6 \mathrm{Cl}^{-}}$was obtained via counteranion exchange, which was accomplished by adding $\mathrm{TBA}^{+} \cdot \mathrm{Cl}^{-}$into a solution of $\mathrm{Cl}^{-} \subset 3^{6+} \cdot 5 \mathrm{PF}_{6}{ }^{-}$in acetonitrile, followed by filtration to collect the corresponding precipitate. This cage complex was characterized by recording its ${ }^{1} \mathrm{H}$ NMR spectrum (Figure S22), ${ }^{1} \mathrm{H}-{ }^{1} \mathrm{H}$ COSY spectrum (Figure S23), ${ }^{1} \mathrm{H}-{ }^{1} \mathrm{H}$ NOESY spectrum (Figure S24), as well as via mass spectrometry (Figure S25) and a single crystal X-ray diffraction analysis (Figure S61).

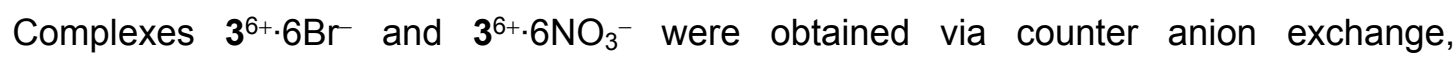
accomplished by adding $\mathrm{TBA}^{+} \cdot \mathrm{Br}^{-}$or $\mathrm{TBA}^{+\cdot} \cdot \mathrm{NO}_{3}{ }^{-}$into a solution of $3^{6+\cdot} \cdot \mathrm{PF}_{6}{ }^{-}$in acetonitrile, followed by filtration to collect the corresponding precipitates. Cage complexes $3^{6+} \cdot 6 \mathrm{Br}$ and $3^{6+} \cdot 6 \mathrm{NO}_{3}{ }^{-}$were characterized by recording the respective ${ }^{1} \mathrm{H}$ NMR spectra (Figures S26 and S27).

Complex $\mathrm{Br}^{-} \subset 3^{6+} .5 \mathrm{PF}_{6}{ }^{-}$was obtained via counterion exchange by adding an excess of $\mathrm{NH}_{4}^{+} \cdot \mathrm{PF}_{6}{ }^{-}$into a solution of $3^{6+} \cdot 6 \mathrm{Br}$ in water, followed by filtration to collect the corresponding precipitate. $\mathrm{Br}^{-} \subset 3^{6+} \cdot 5 \mathrm{PF}_{6}{ }^{-}$was characterized by recording its ${ }^{1} \mathrm{H}$ NMR spectrum (Figure S28).

Complex $\mathrm{NO}_{3}{ }^{-} \subset 3^{6+} \cdot 5 \mathrm{PF}_{6}{ }^{-}$was obtained via counterion exchange by adding excess amount of $\mathrm{NH}_{4}^{+} \cdot \mathrm{PF}_{6}^{-}$into a solution of $3^{6+} \cdot 6 \mathrm{NO}_{3}^{-}$in water. However, a ${ }^{1} \mathrm{H}$ NMR spectroscopic analysis revealed that the sample ostensibly ascribed to $\mathrm{NO}_{3}{ }^{-} \subset 3^{6+} \cdot 5 \mathrm{PF}_{6}{ }^{-}$ also contains a small quantity of the "empty" cage $3^{6+} \cdot 6 \mathrm{PF}_{6}{ }^{-}$(Figure S29). 


\section{NMR spectra and HRMS spectra}

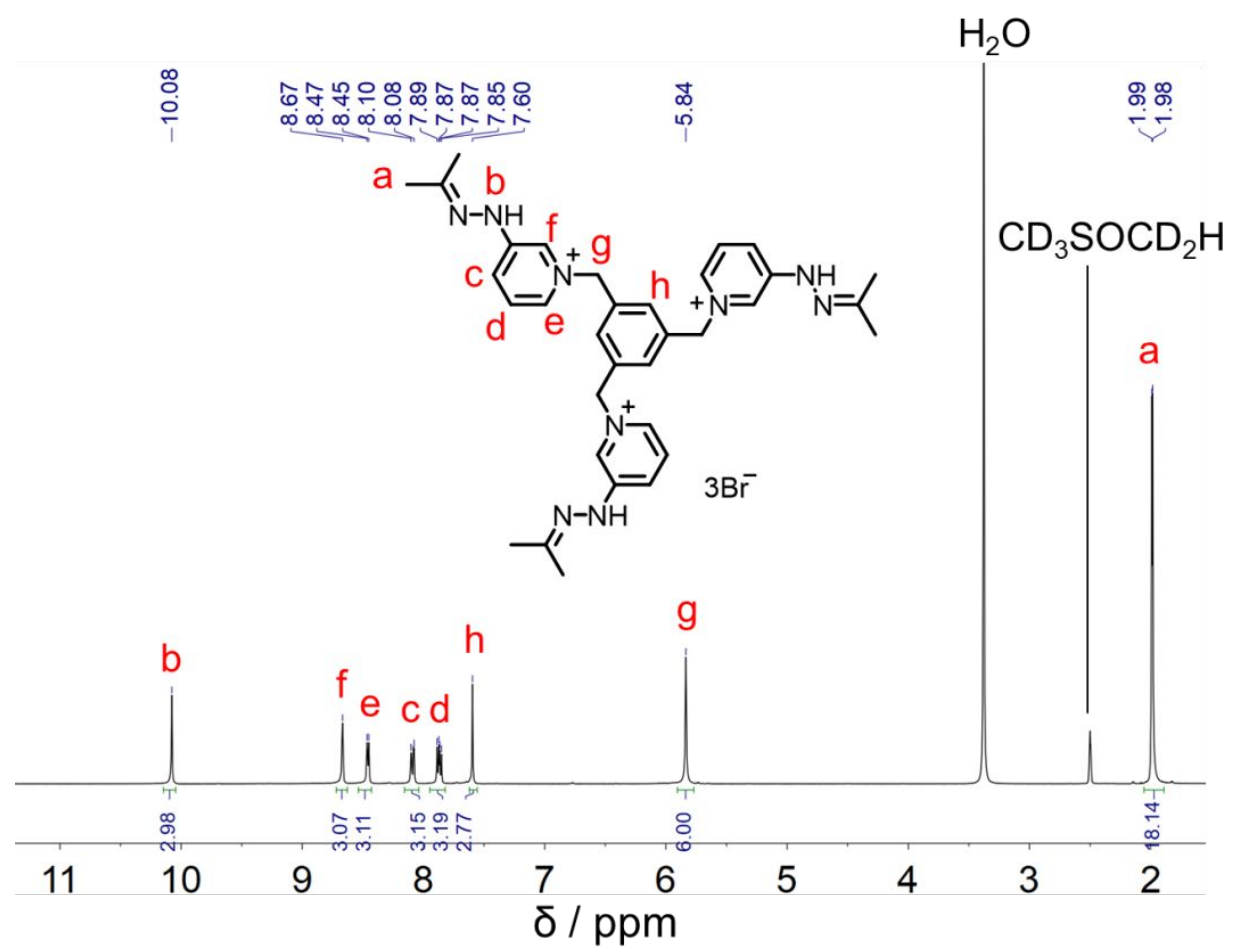

Figure S1. ${ }^{1} \mathrm{H}$ NMR spectrum $\left(400 \mathrm{MHz}\right.$, DMSO- $\left.d_{6}, 298 \mathrm{~K}\right)$ of $1^{3+} \cdot 3 \mathrm{Br}-$.

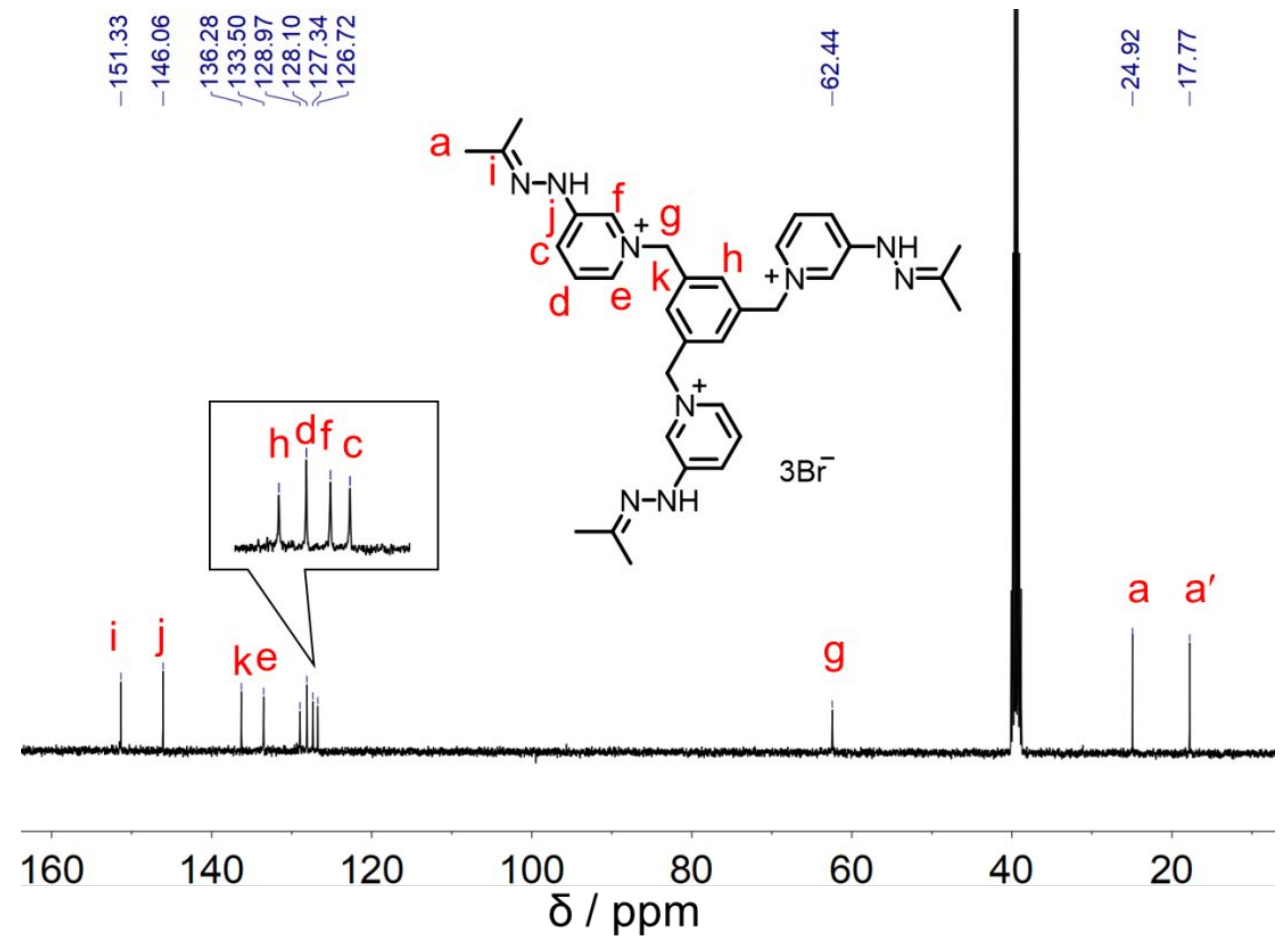

Figure S2. ${ }^{13} \mathrm{C}$ NMR spectrum (100 MHz, DMSO- $d_{6}, 298 \mathrm{~K}$ ) of $1^{3+} \cdot 3 \mathrm{Br}^{-}$. 


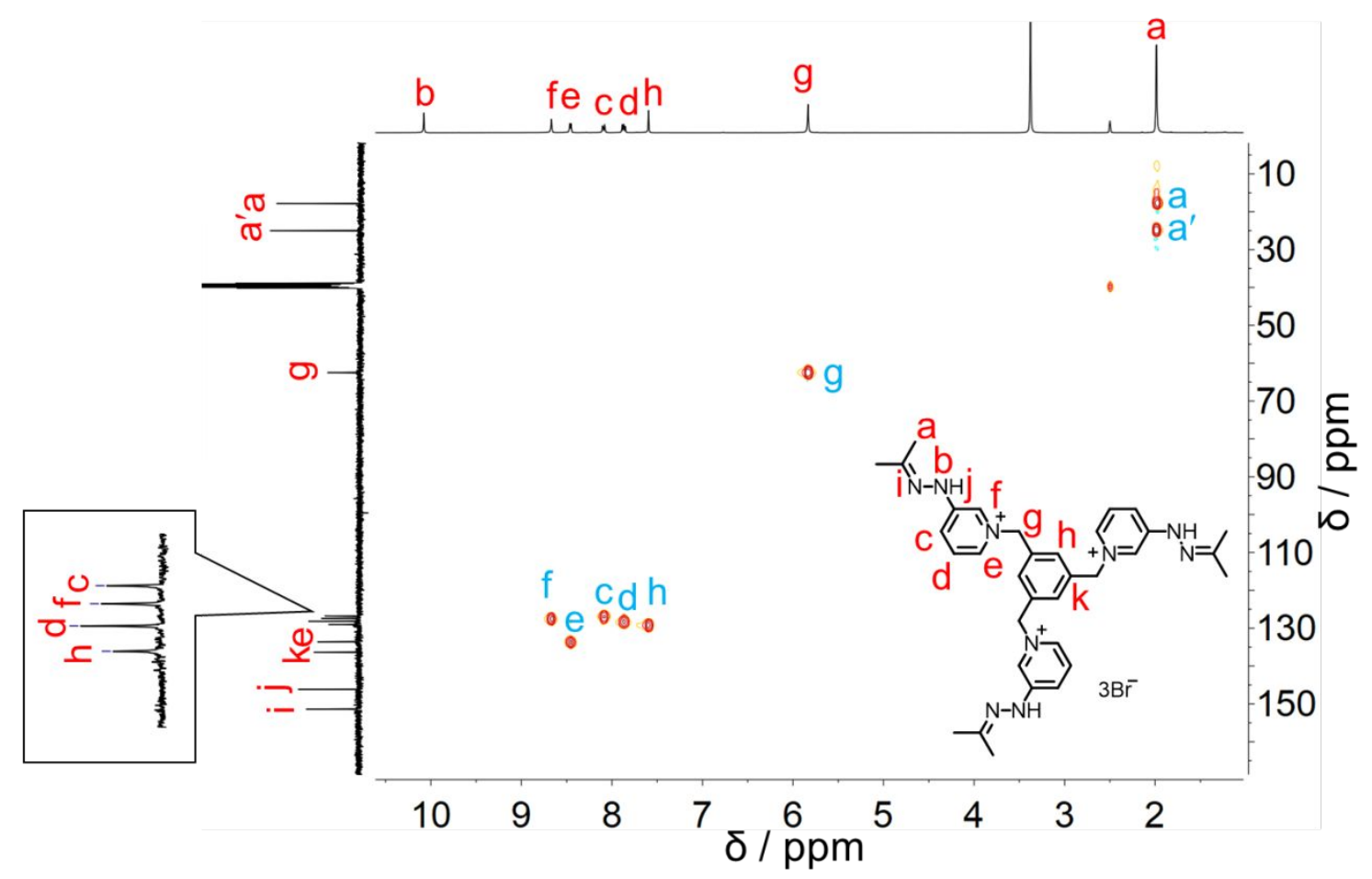

Figure S3. HSQC spectrum (DMSO- $d_{6}, 298 \mathrm{~K}$ ) of $\mathbf{1}^{3+} \cdot 3 \mathrm{Br}^{-}$.

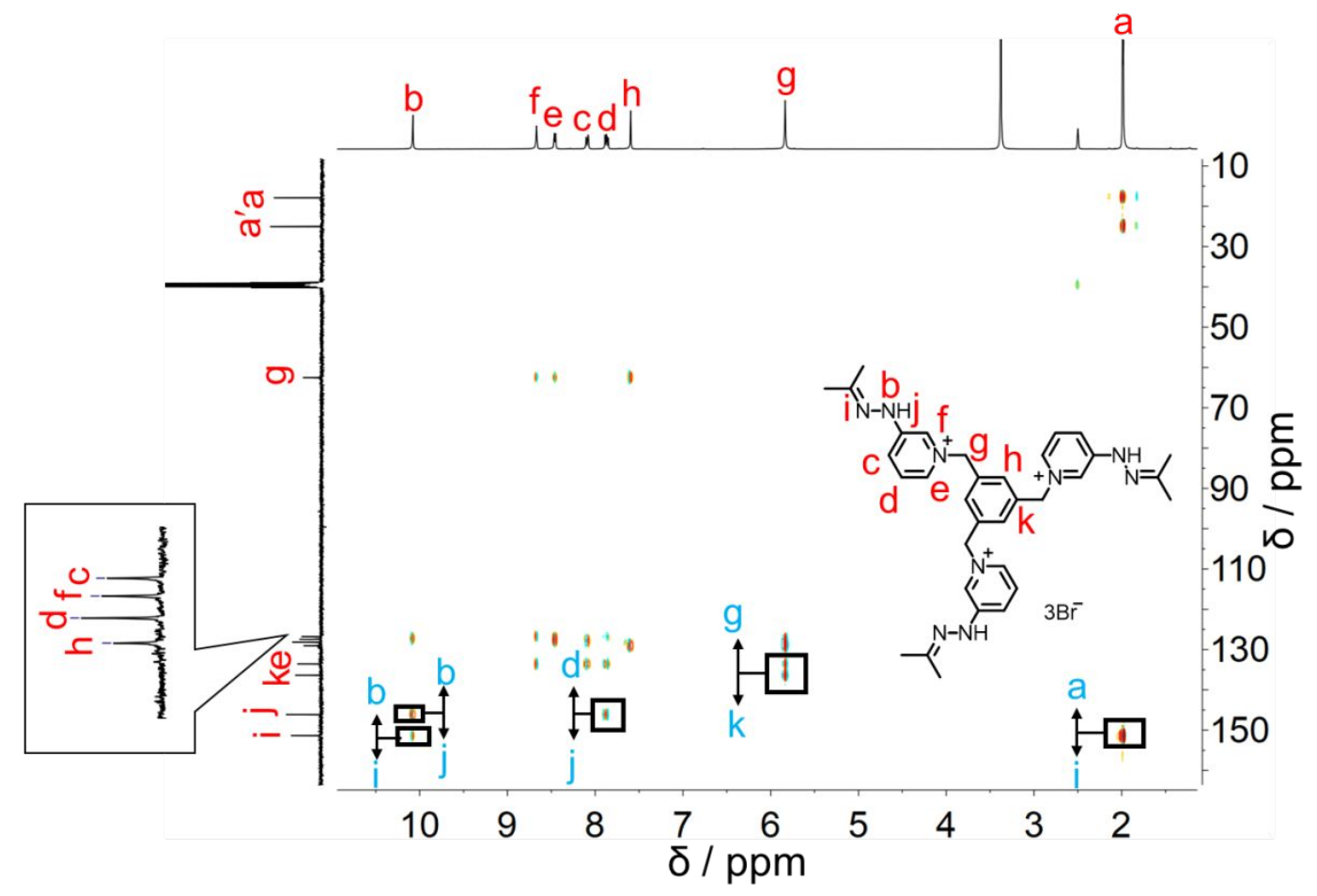

Figure S4. HMBC spectrum (DMSO- $d_{6}, 298 \mathrm{~K}$ ) of $\mathbf{1}^{3+} \cdot 3 \mathrm{Br}^{-}$. 


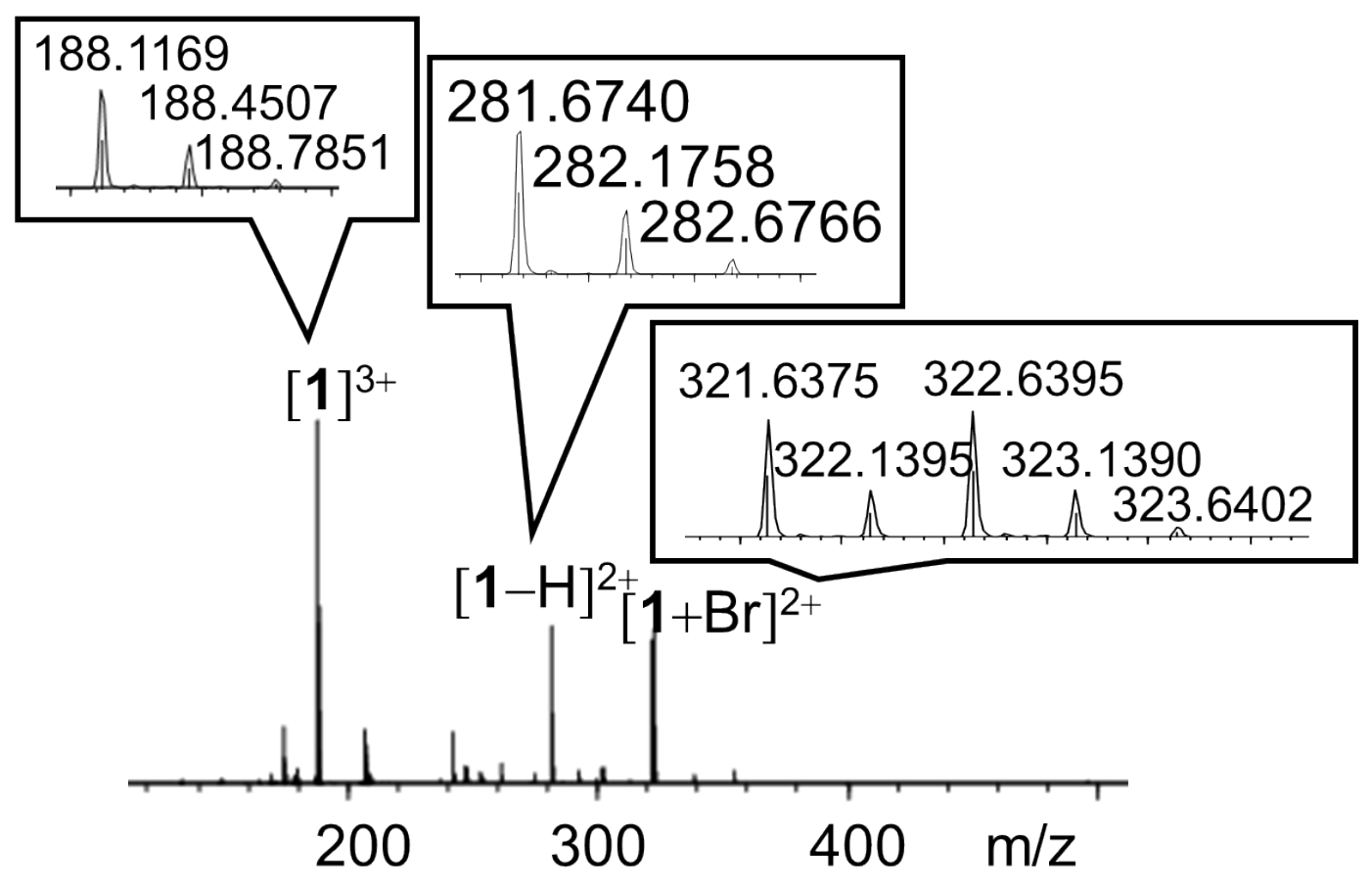

Figure S5. ESI-HRMS of $1^{3+} \cdot 3 \mathrm{Br}$.

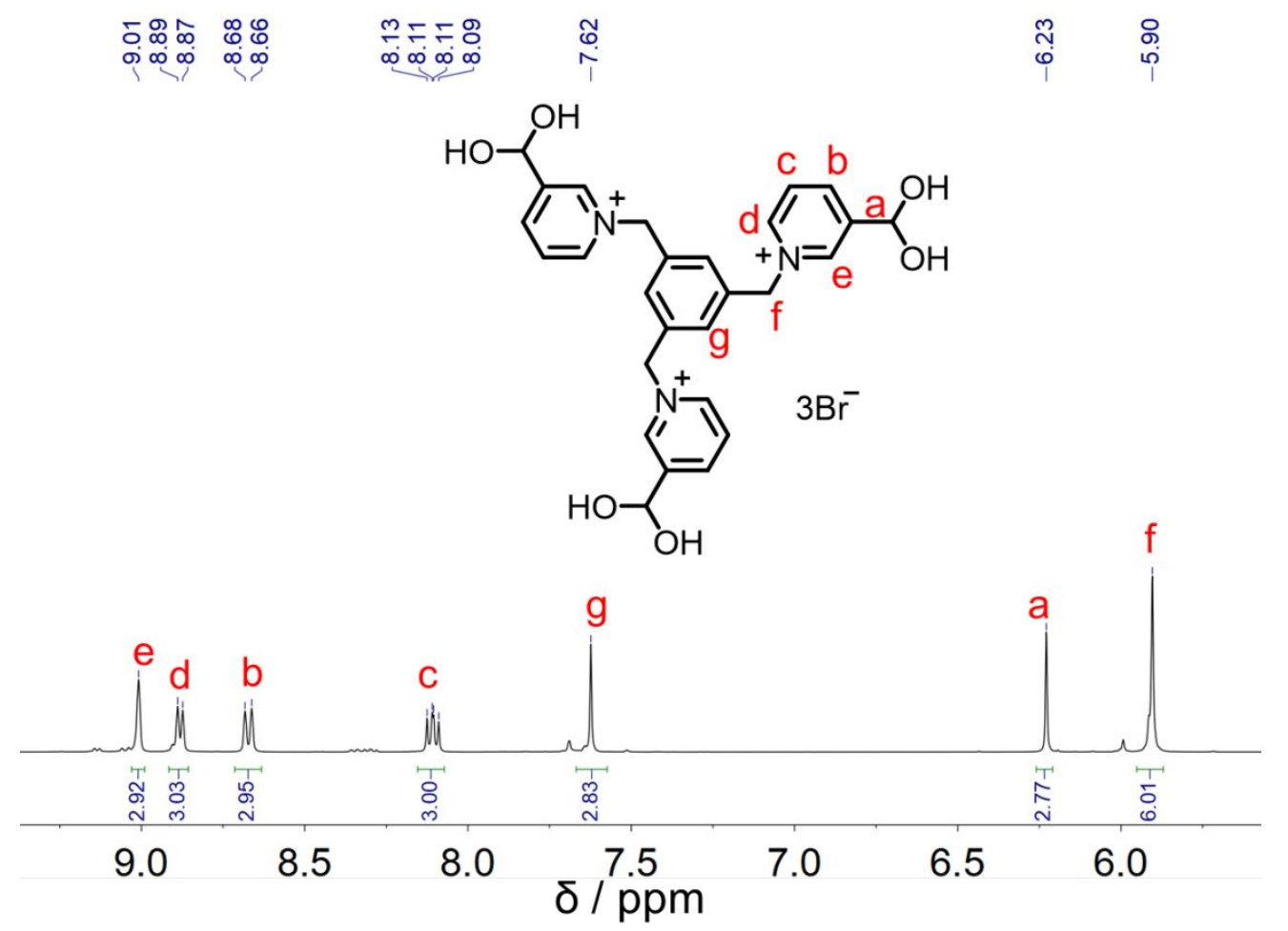

Figure S6. ${ }^{1} \mathrm{H}$ NMR spectrum $\left(400 \mathrm{MHz}, \mathrm{D}_{2} \mathrm{O}, 298 \mathrm{~K}\right)$ of $2^{3+} \cdot 3 \mathrm{Br}^{-}$. In water, the aldehyde units undergo hydrolysis. 


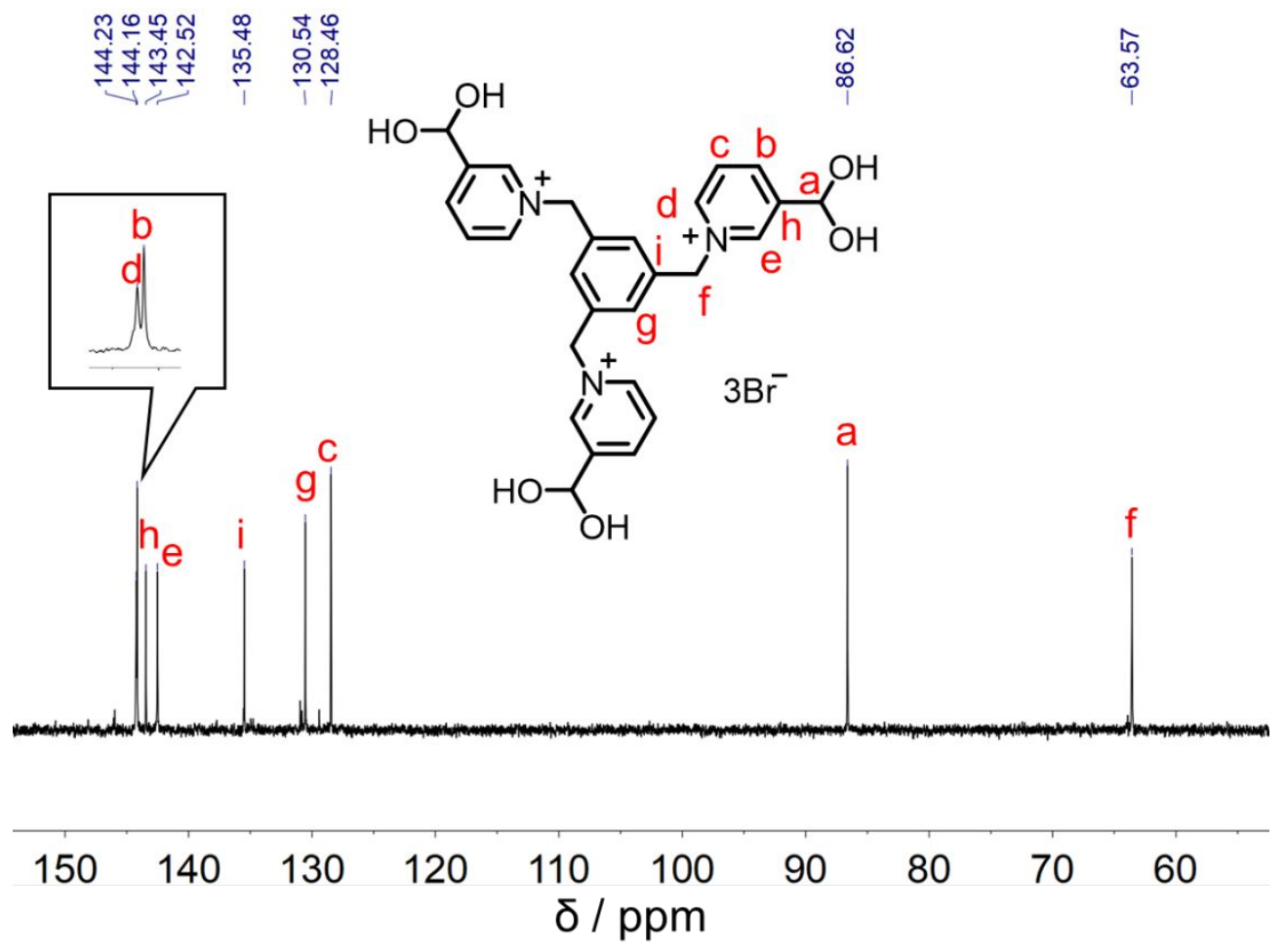

Figure S7. ${ }^{13} \mathrm{C}$ NMR spectrum $\left(100 \mathrm{MHz}, \mathrm{D}_{2} \mathrm{O}, 298 \mathrm{~K}\right.$ ) of $\mathbf{2}^{3+} \cdot 3 \mathrm{Br}^{-}$. In water, the aldehyde units undergo hydrolysis.

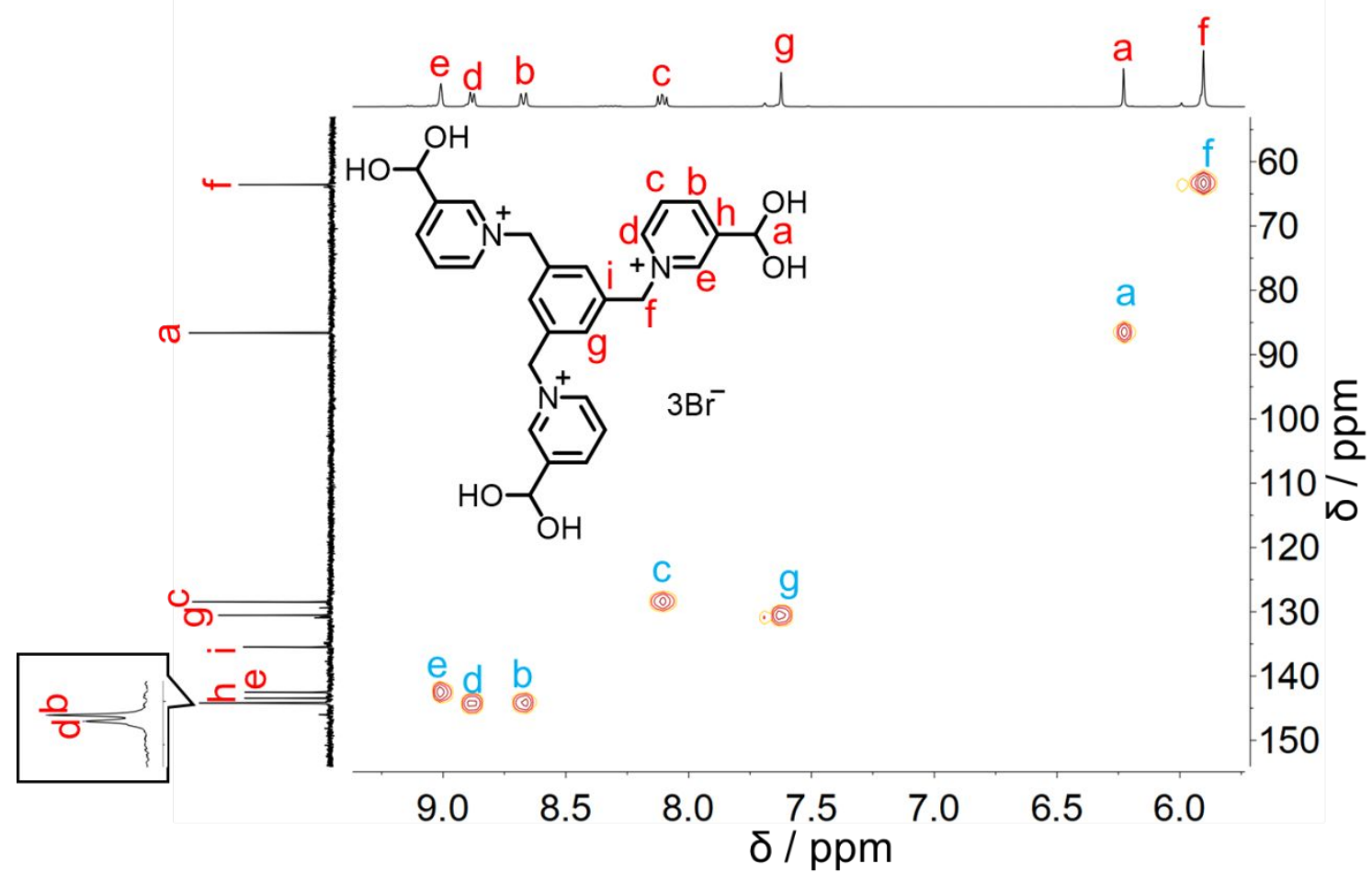

Figure S8. HSQC spectrum $\left(\mathrm{D}_{2} \mathrm{O}, 298 \mathrm{~K}\right)$ of $2^{3+} \cdot 3 \mathrm{Br}^{-}$. In water, the aldehyde units undergo hydrolysis. 


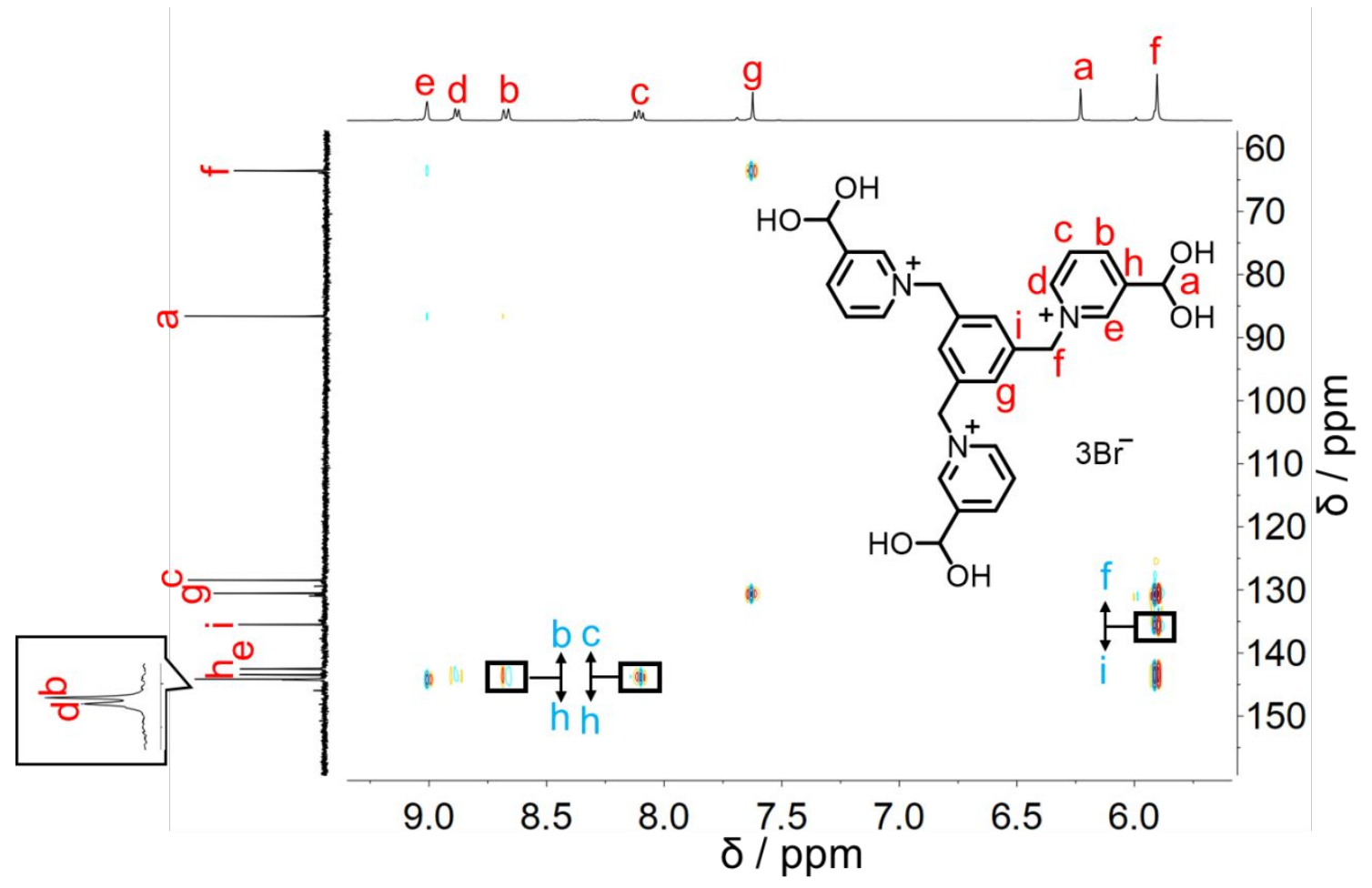

Figure S9. HMBC spectrum $\left(\mathrm{D}_{2} \mathrm{O}, 298 \mathrm{~K}\right)$ of $2^{3+} \cdot 3 \mathrm{Br}^{-}$. In water, the aldehyde units undergo hydrolysis.

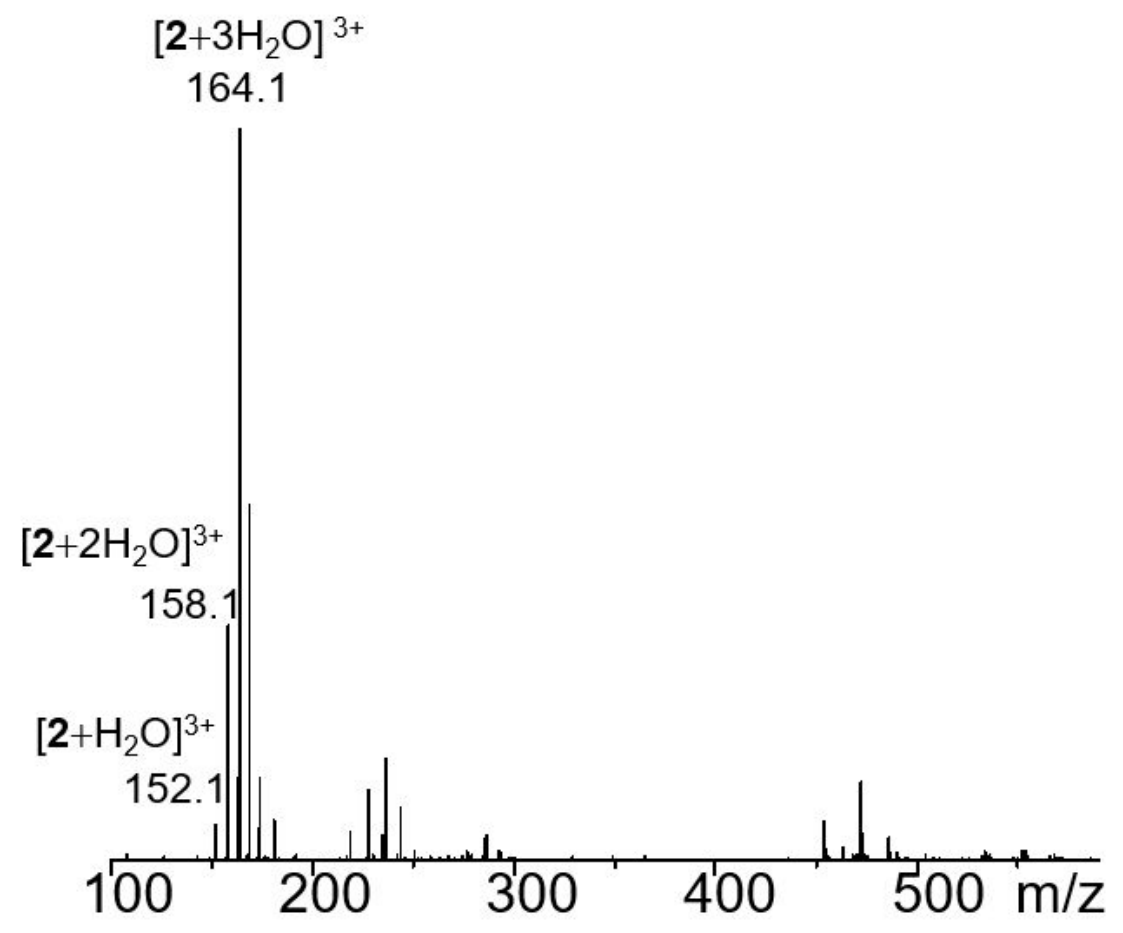

Figure S10. ESI-MS of $\mathbf{2}^{3+} \cdot 3 \mathrm{Br}$. 


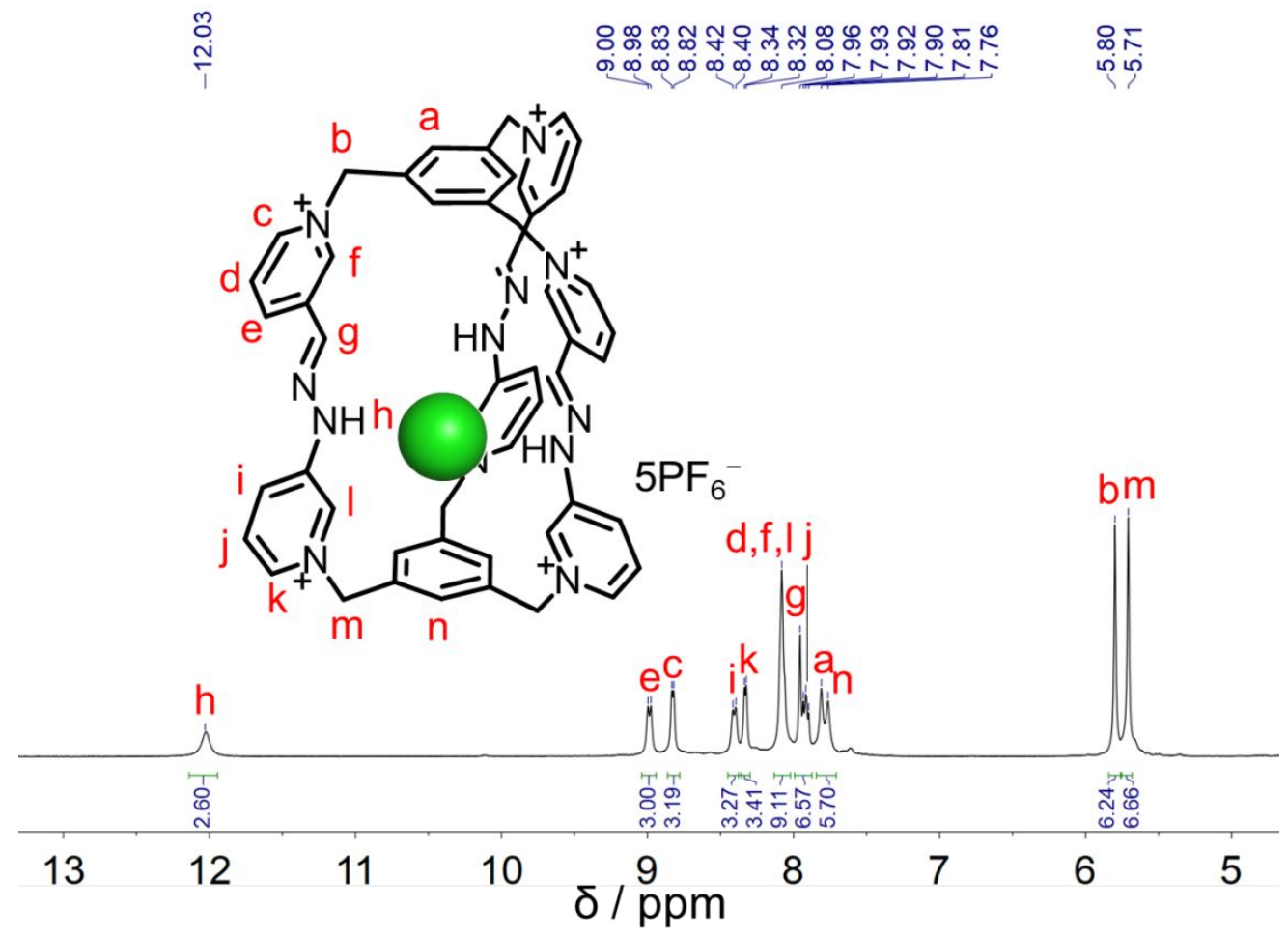

Figure S11. ${ }^{1} \mathrm{H}$ NMR spectrum $\left(500 \mathrm{MHz}, \mathrm{CD}_{3} \mathrm{CN}, 298 \mathrm{~K}\right)$ of $\mathrm{Cl}^{-} \subset 3^{6+} \cdot 5 \mathrm{PF}_{6}{ }^{-}$.

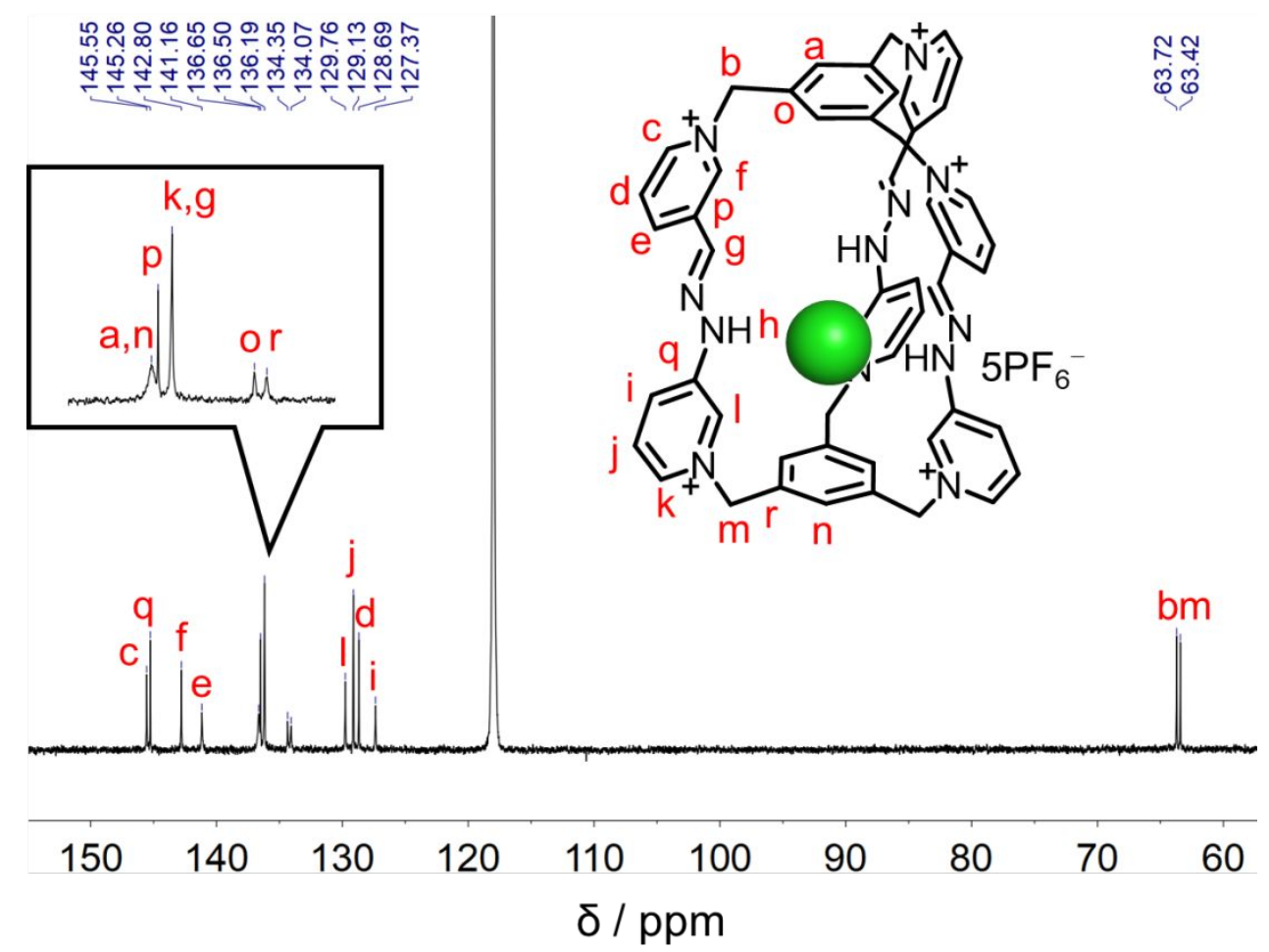

Figure S12. ${ }^{13} \mathrm{C}$ NMR spectrum $\left(125 \mathrm{MHz}, \mathrm{CD}_{3} \mathrm{CN}, 298 \mathrm{~K}\right)$ of $\mathrm{Cl}^{-} \subset \mathbf{3}^{6+} \cdot 5 \mathrm{PF}_{6}{ }^{-}$. 


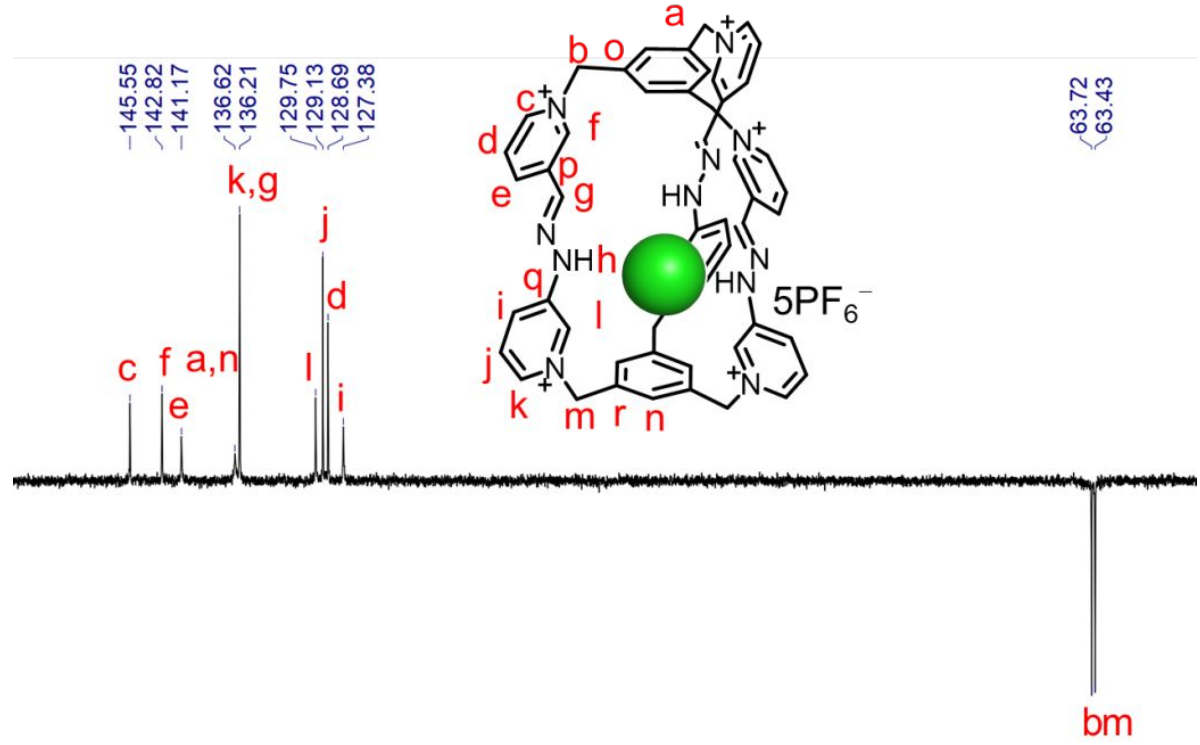

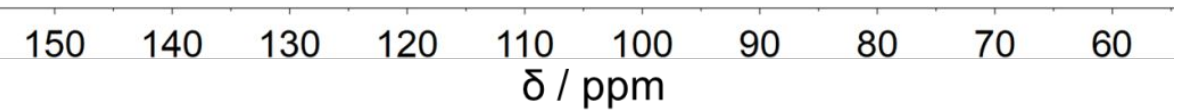

Figure S13. DEPT-135 spectrum (125 MHz, $\left.\mathrm{CD}_{3} \mathrm{CN}, 298 \mathrm{~K}\right)$ of $\mathrm{Cl}^{-} \subset 3^{6+} \cdot 5 \mathrm{PF}_{6}^{-}$.

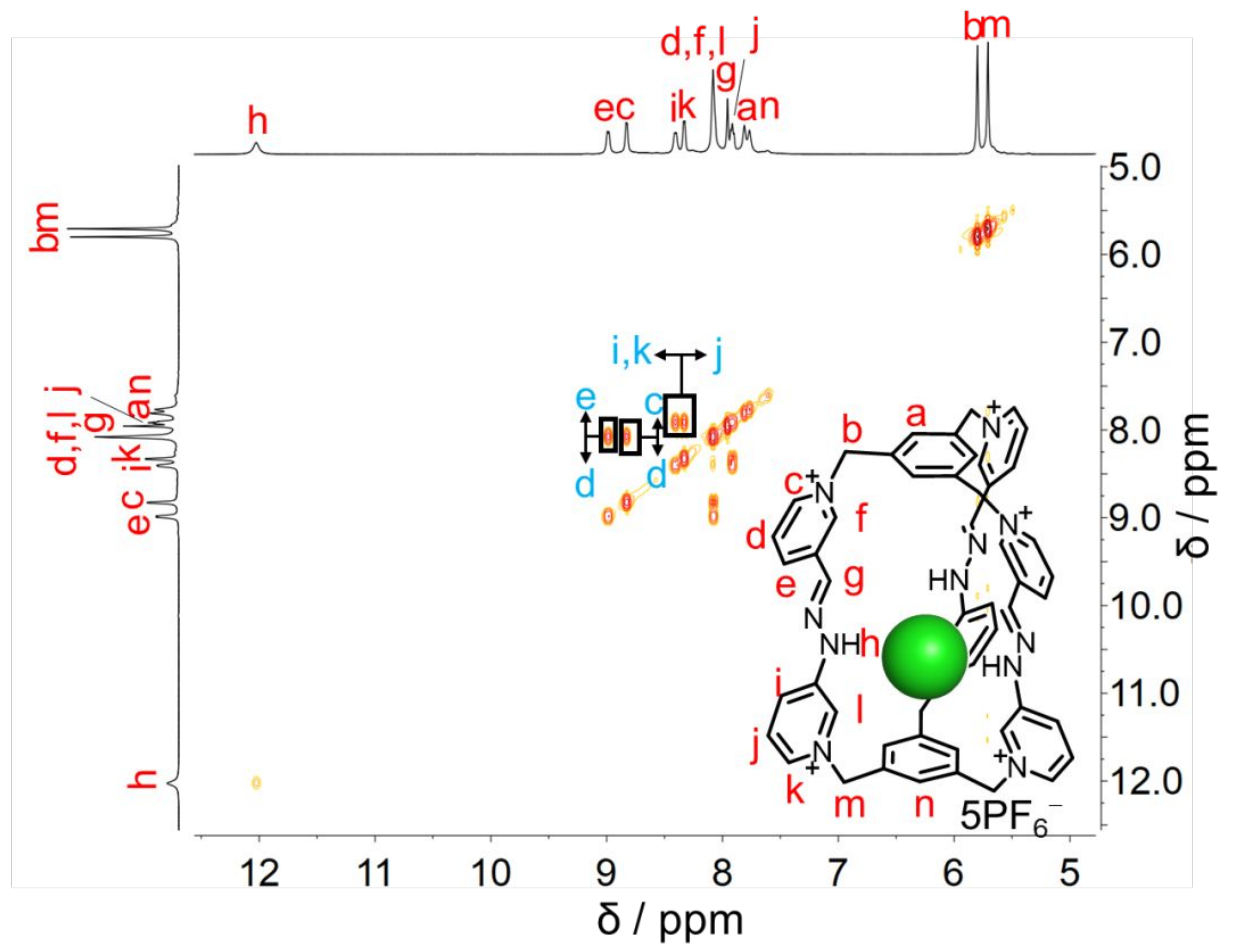

Figure S14. ${ }^{1} \mathrm{H}-{ }^{1} \mathrm{H}$ COSY spectrum $\left(500 \mathrm{MHz}, \mathrm{CD}_{3} \mathrm{CN}, 298 \mathrm{~K}\right)$ of $\mathrm{Cl}^{-} \subset 3^{6+} \cdot 5 \mathrm{PF}_{6}-$. 


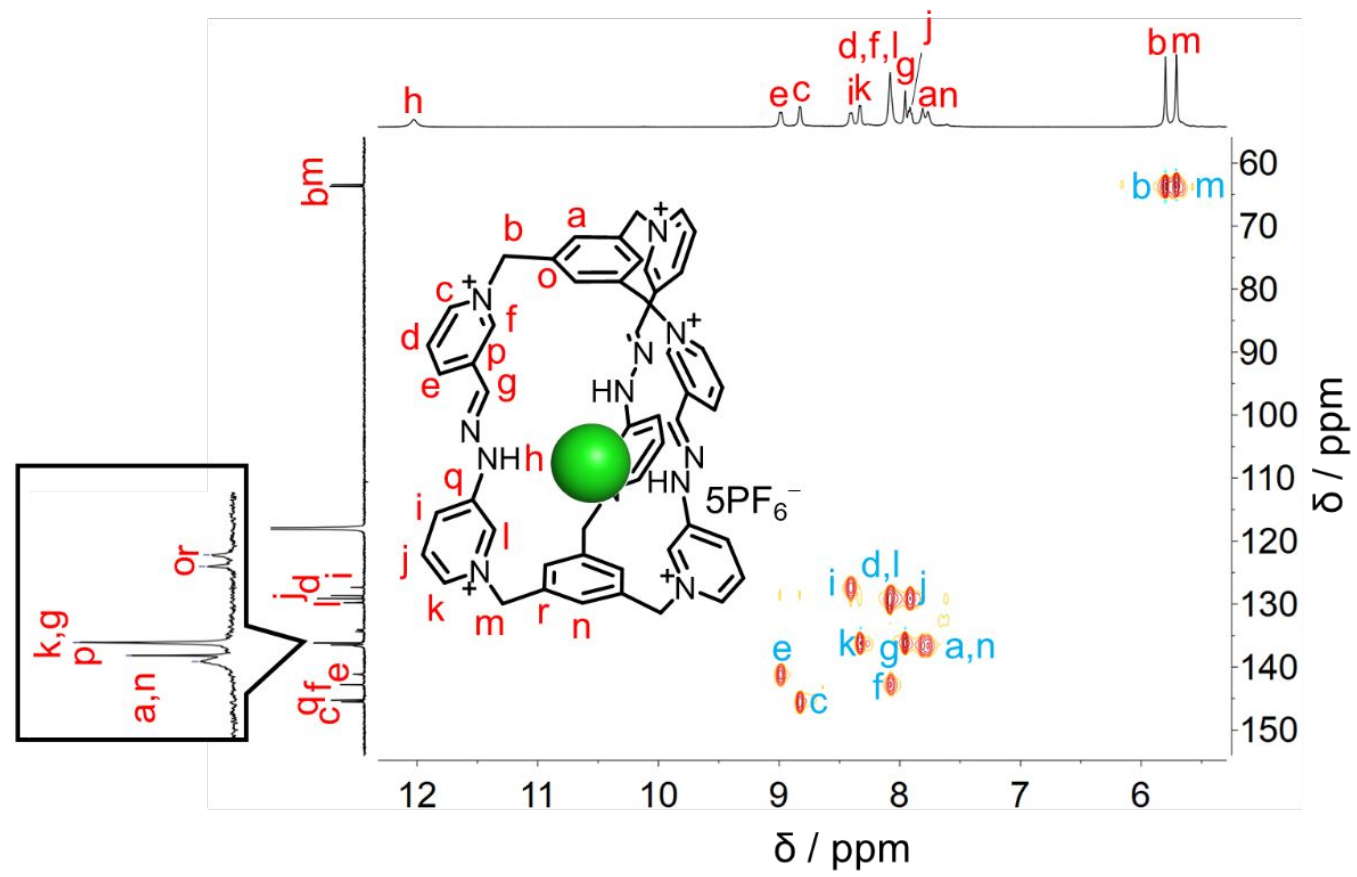

Figure S15. $\mathrm{HSQC}$ spectrum $\left(\mathrm{CD}_{3} \mathrm{CN}, 298 \mathrm{~K}\right)$ of $\mathrm{Cl}^{-} \subset 3^{6+} \cdot 5 \mathrm{PF}_{6}-$.

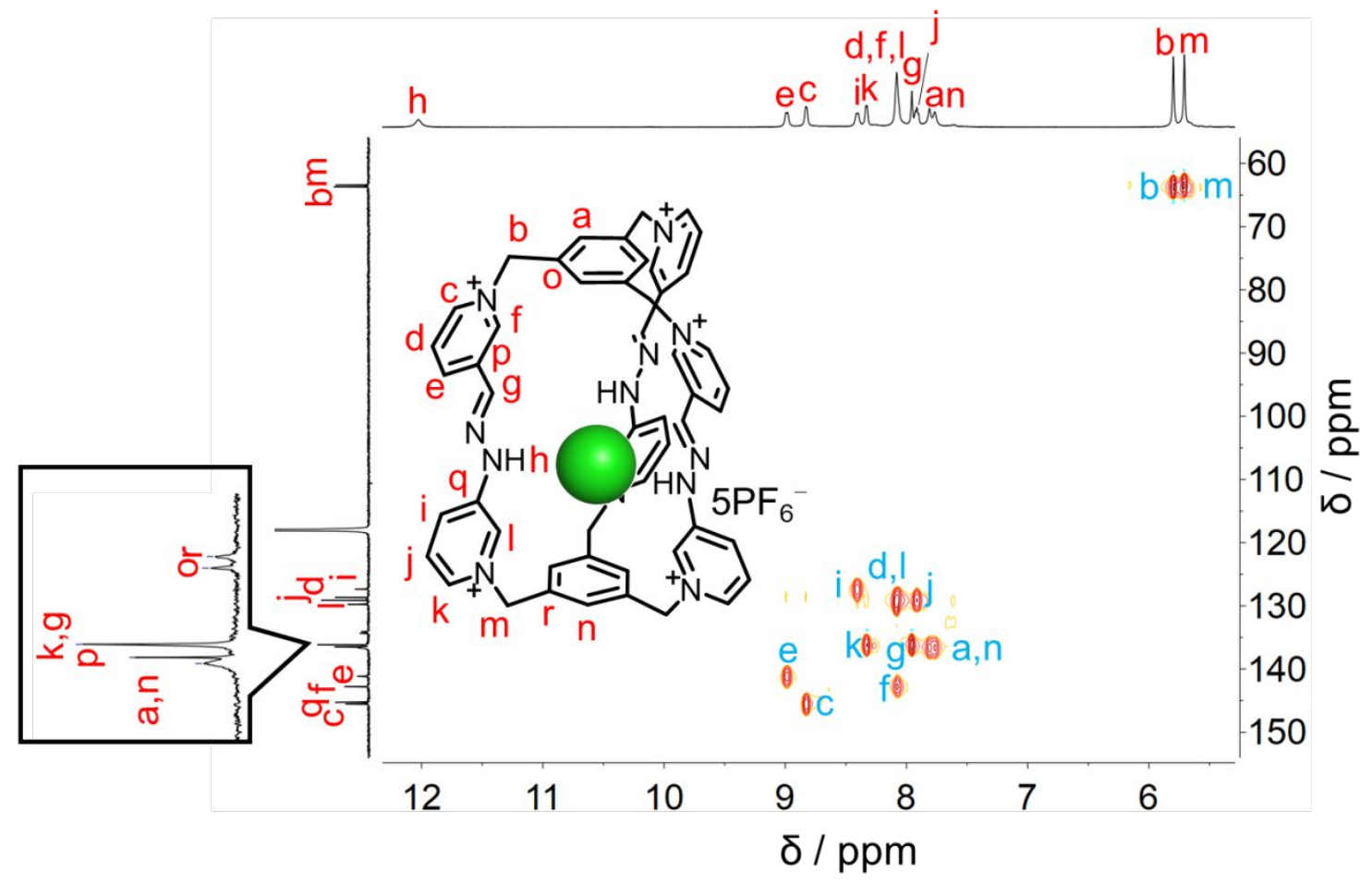

Figure S16. $\mathrm{HMBC}$ spectrum $\left(\mathrm{CD}_{3} \mathrm{CN}, 298 \mathrm{~K}\right)$ of $\mathrm{Cl}^{-} \subset 3^{6+} \cdot 5 \mathrm{PF}_{6}^{-}$. 


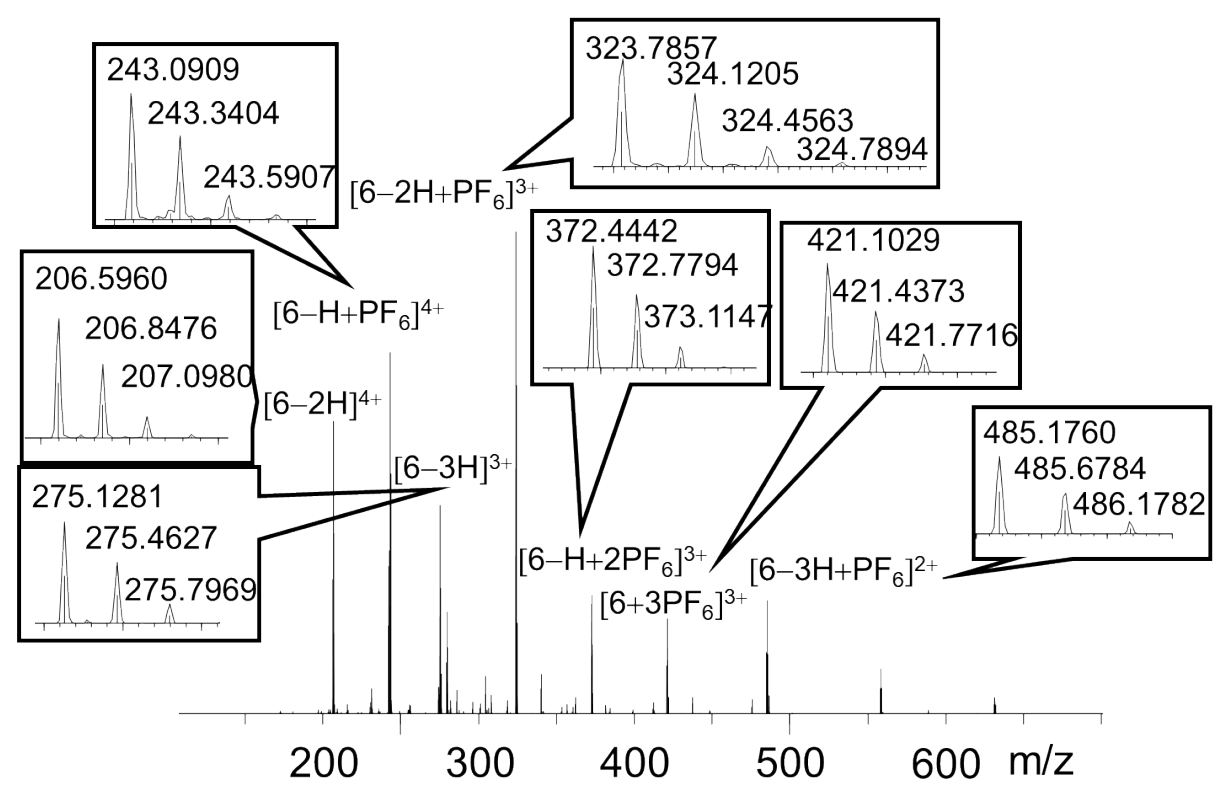

Figure S17. ESI-HRMS of $\mathrm{Cl}^{-} \subset \mathbf{3}^{6+} \cdot 5 \mathrm{PF}_{6}{ }^{-}$. The signals labeled in the spectrum correspond to molecular cations that contain four, three and two positive charges, respectively; These are formed presumably through either loss of protons or addition of $\mathrm{PF}_{6}{ }^{-}$counter anions.

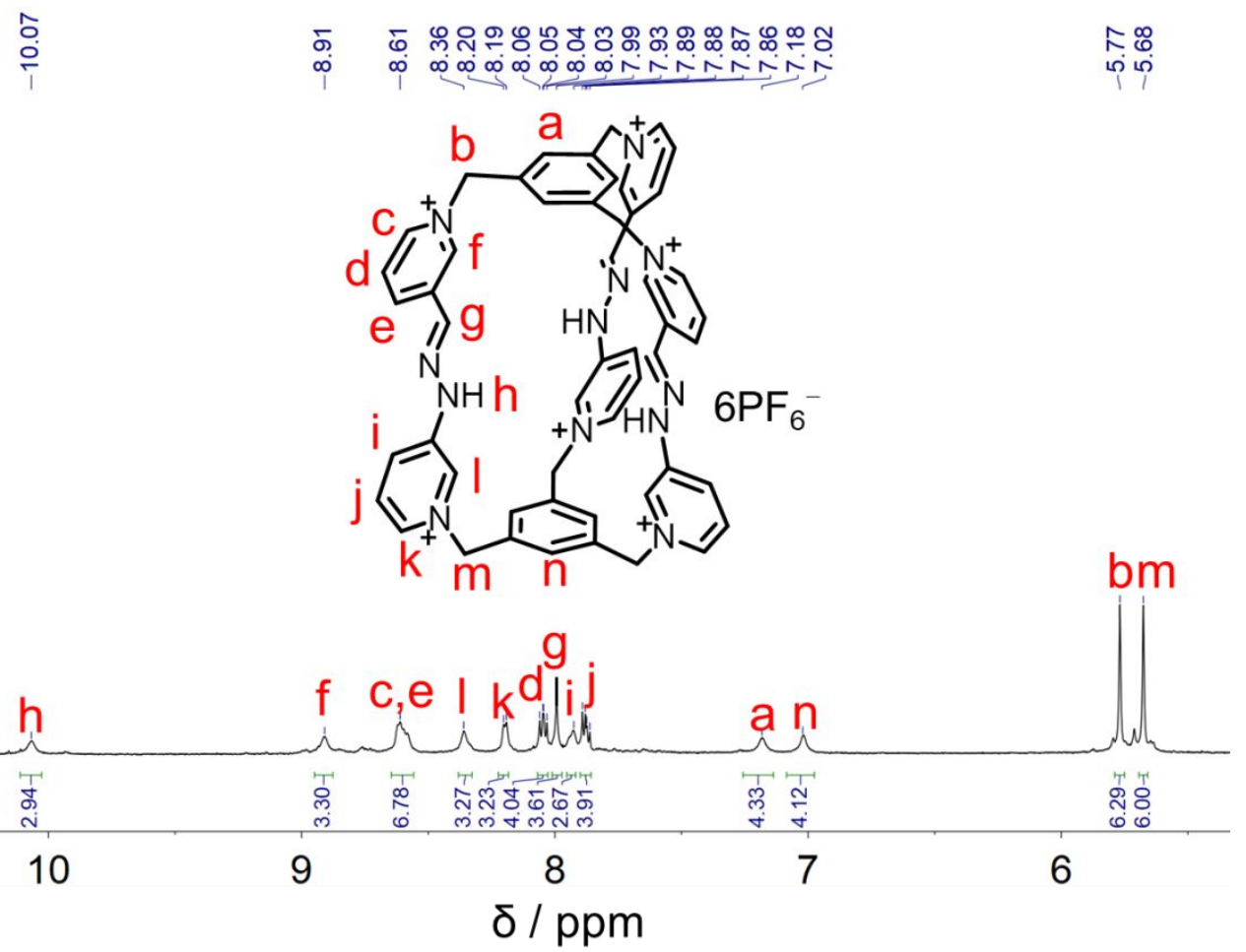

Figure S18. ${ }^{1} \mathrm{H}$ NMR spectrum $\left(500 \mathrm{MHz}, \mathrm{CD}_{3} \mathrm{CN}, 298 \mathrm{~K}\right)$ of $3^{6+} \cdot 6 \mathrm{PF}_{6}{ }^{-}$. 

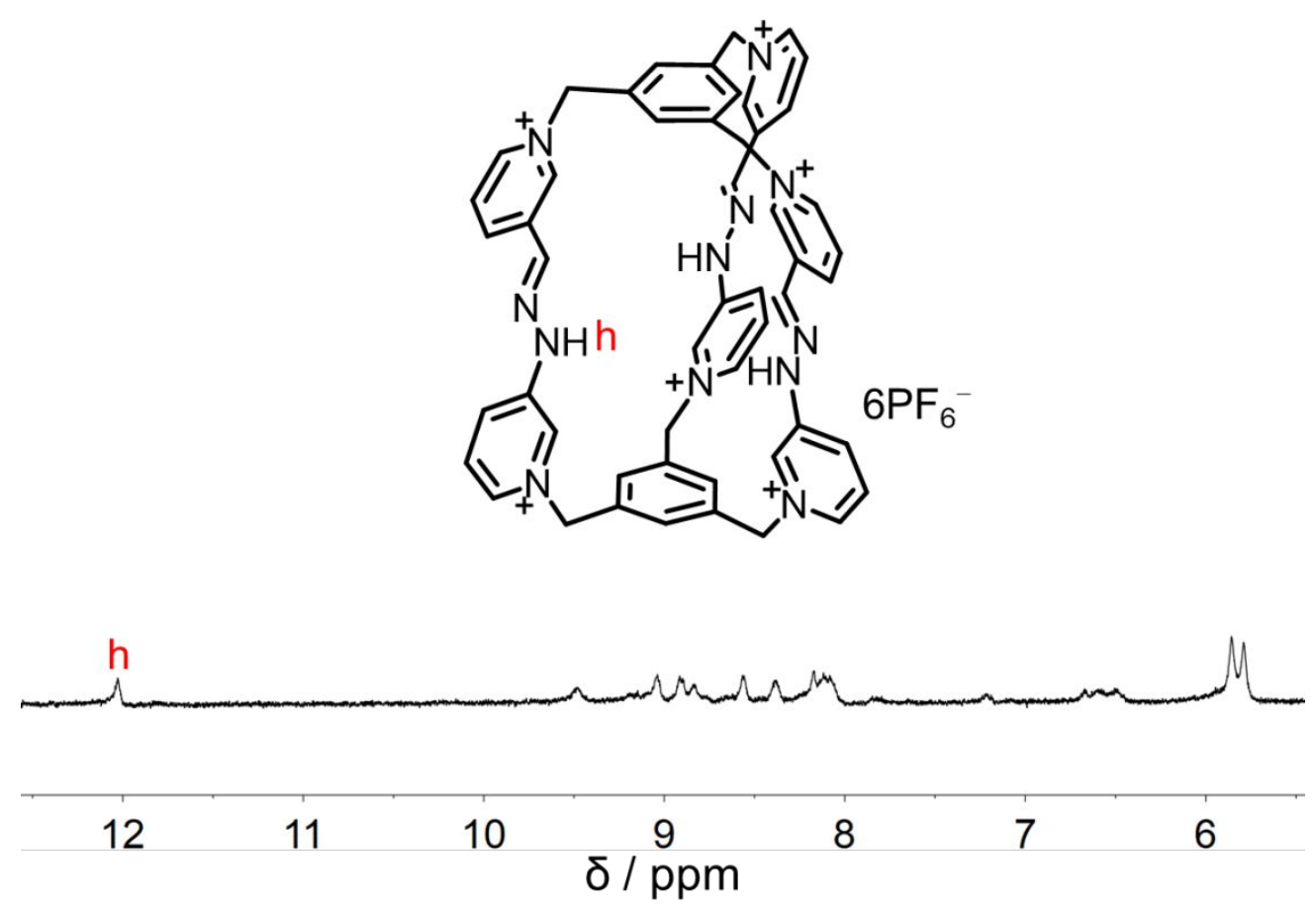

Figure S19. ${ }^{1} \mathrm{H}$ NMR spectrum $\left(400 \mathrm{MHz}, \mathrm{DMSO}-d_{6}, 298 \mathrm{~K}\right)$ of $3^{6+} \cdot 6 \mathrm{PF}_{6}{ }^{-}$.

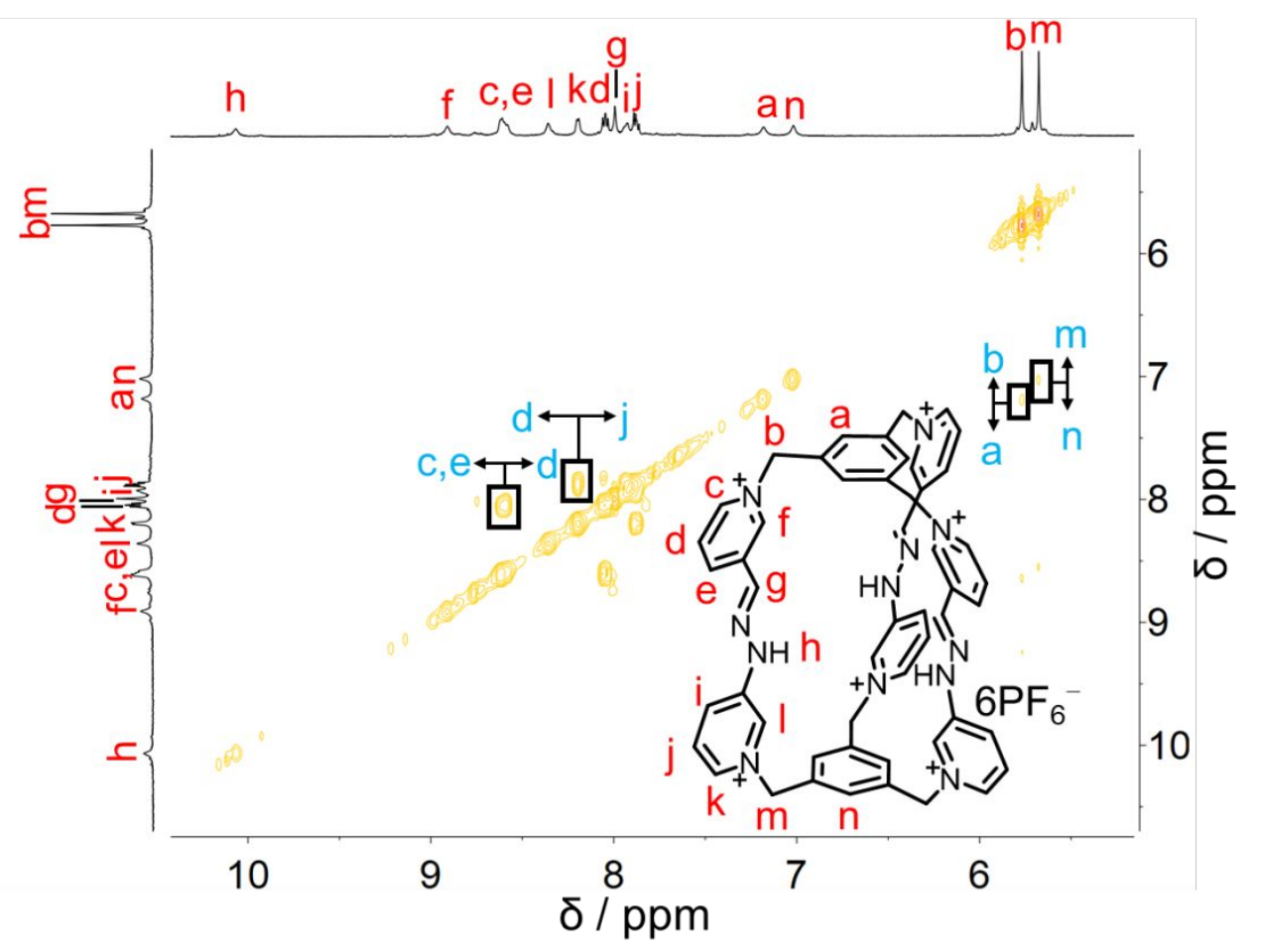

Figure S20. ${ }^{1} \mathrm{H}-{ }^{-1} \mathrm{H}$ COSY spectrum $\left(500 \mathrm{MHz}, \mathrm{CD}_{3} \mathrm{CN}, 298 \mathrm{~K}\right)$ of $3^{6+} \cdot 6 \mathrm{PF}_{6}{ }^{-}$. 


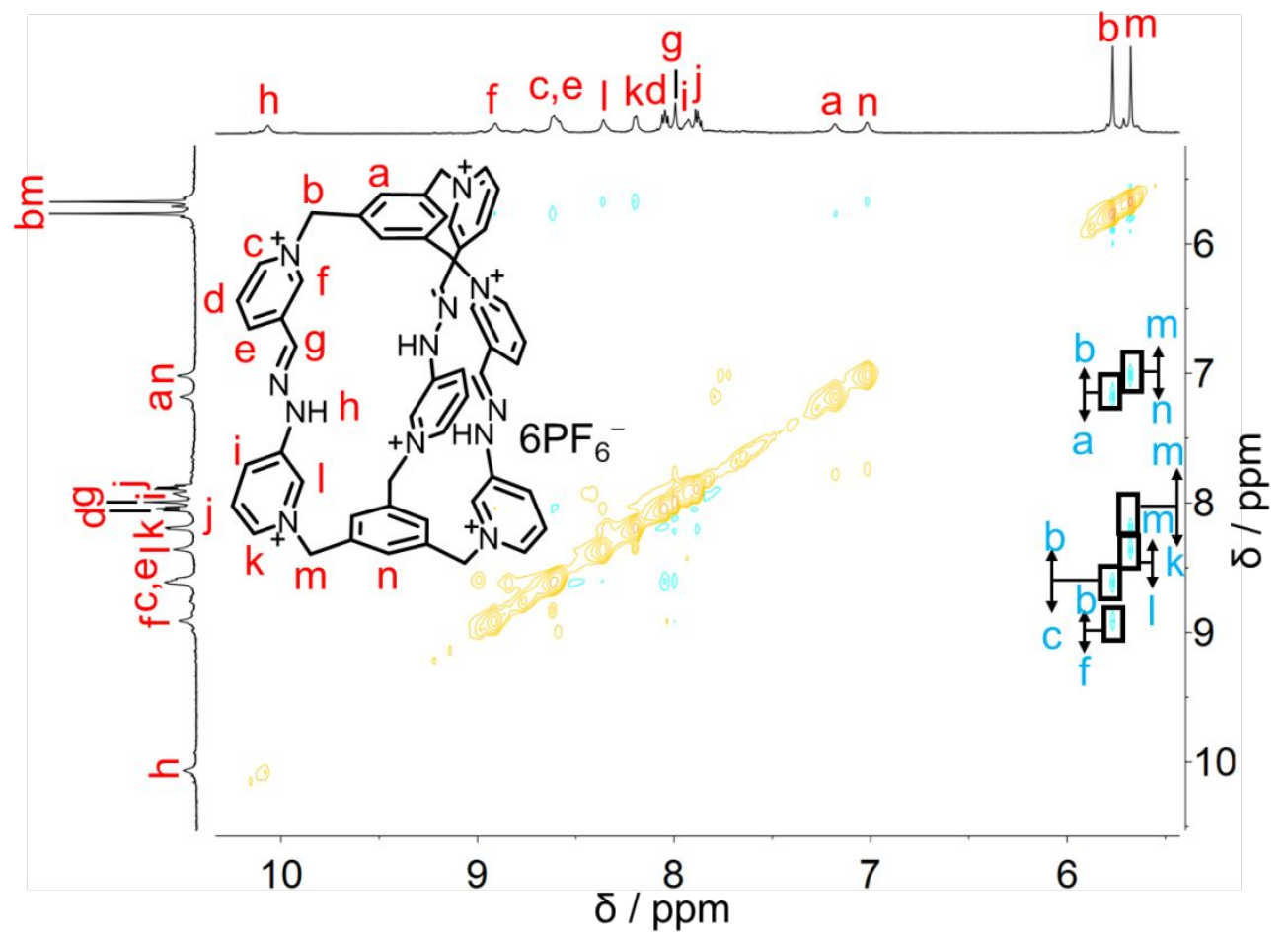

Figure S21. ${ }^{1} \mathrm{H}-{ }^{-1} \mathrm{H}$ NOESY spectrum $\left(500 \mathrm{MHz}, \mathrm{CD}_{3} \mathrm{CN}, 298 \mathrm{~K}\right)$ of $3^{6+} \cdot 6 \mathrm{PF}_{6}{ }^{-}$.
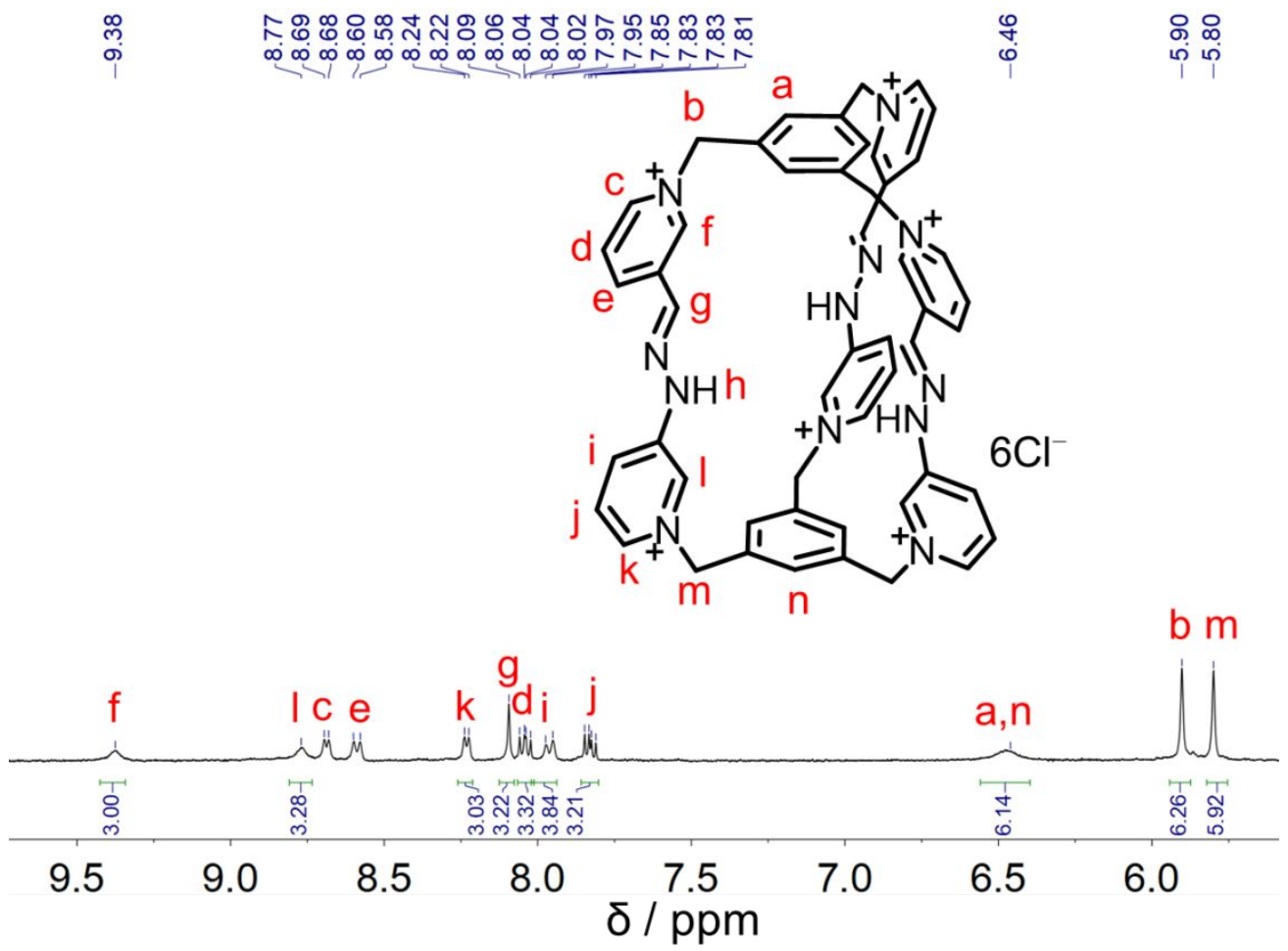

Figure S22. ${ }^{1} \mathrm{H}$ NMR spectrum $\left(500 \mathrm{MHz}, \mathrm{D}_{2} \mathrm{O}, 298 \mathrm{~K}\right)$ of $3^{6+} \cdot 6 \mathrm{Cl}^{-}$. 


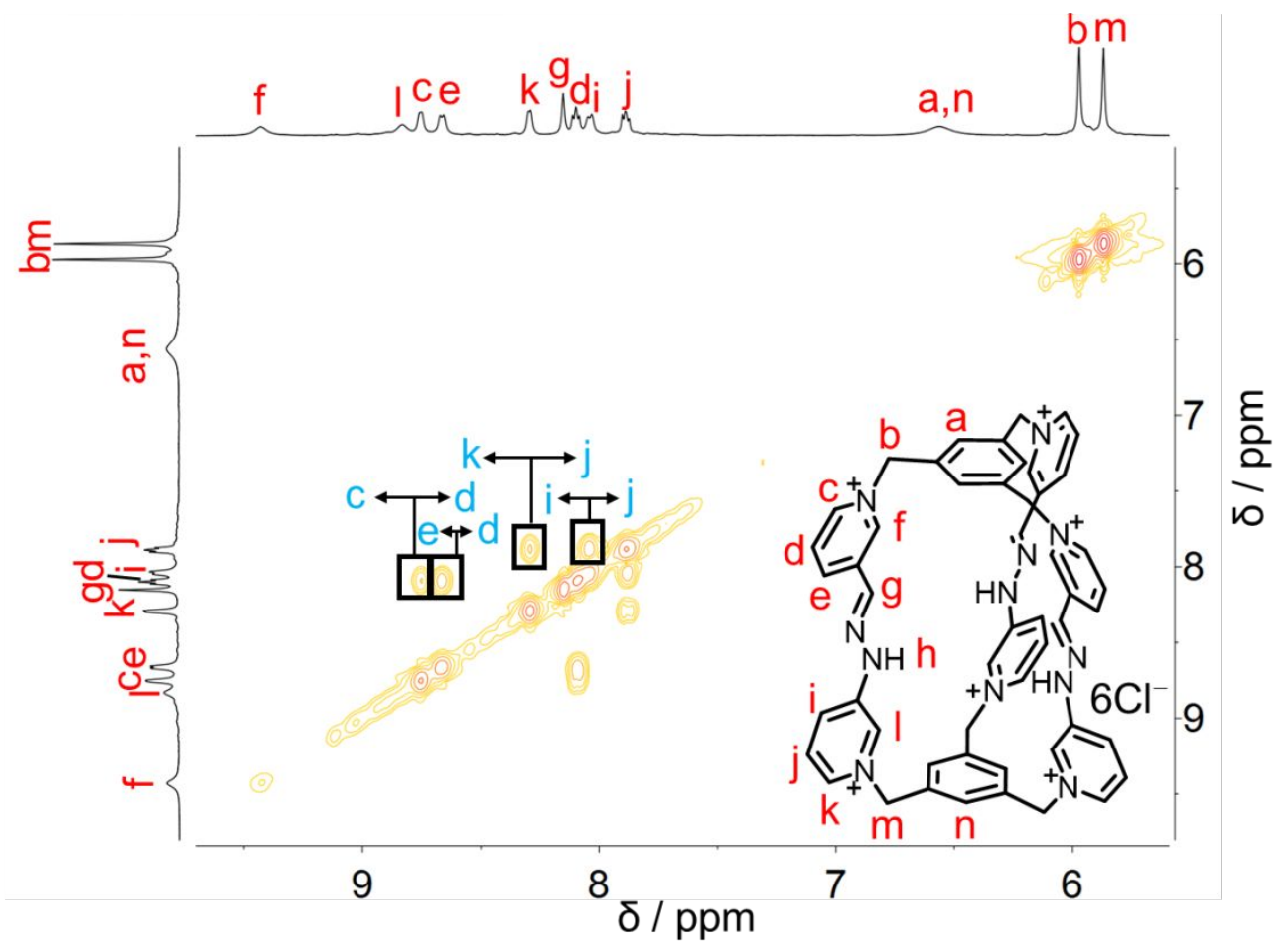

Figure S23. ${ }^{1} \mathrm{H}-{ }^{1} \mathrm{H}$ COSY spectrum $\left(500 \mathrm{MHz}, \mathrm{D}_{2} \mathrm{O}, 298 \mathrm{~K}\right)$ of $3^{6+\cdot} \cdot 6 \mathrm{Cl}^{-}$.

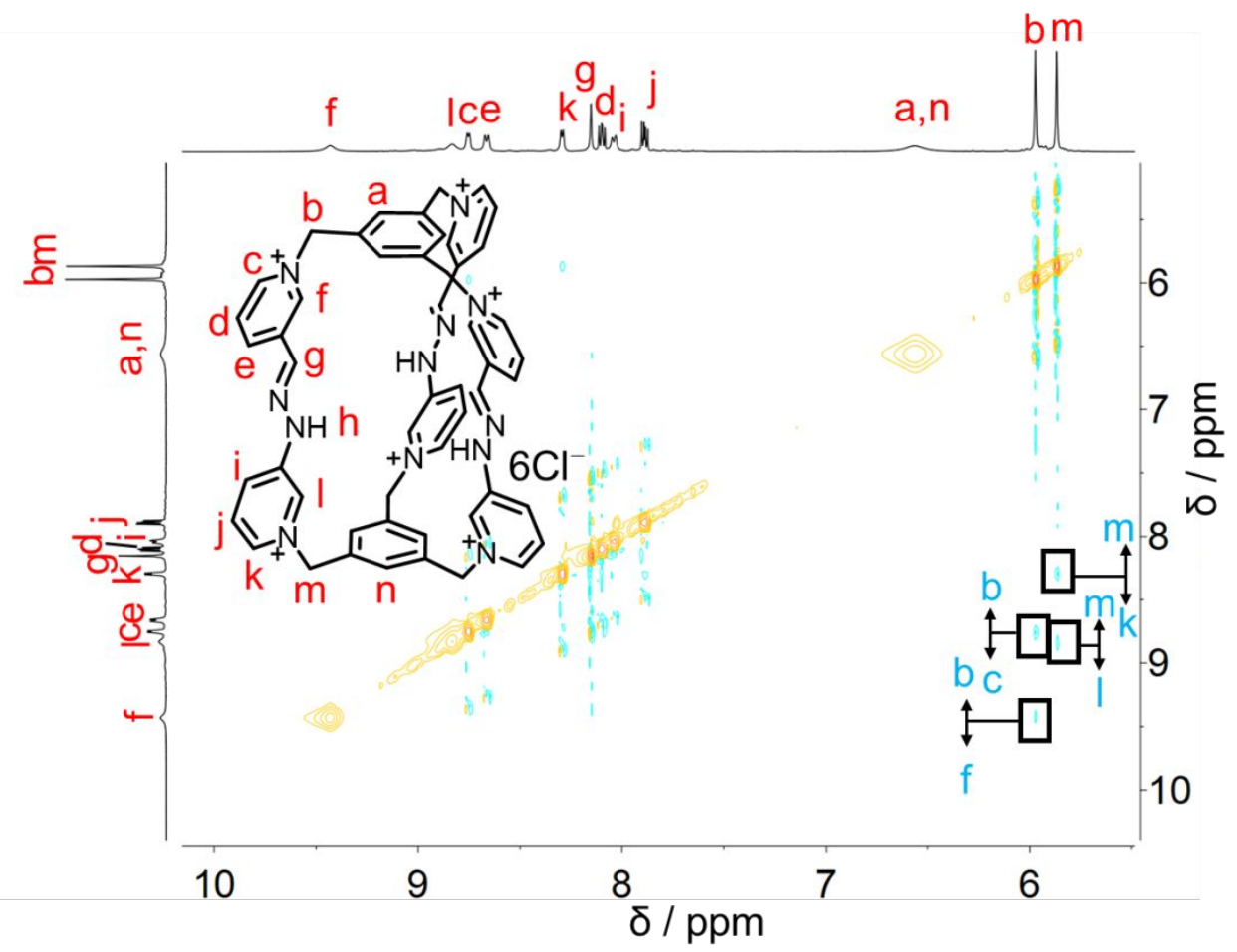

Figure S24. ${ }^{1} \mathrm{H}-{ }^{1} \mathrm{H}$ NOESY spectrum $\left(500 \mathrm{MHz}, \mathrm{D}_{2} \mathrm{O}, 298 \mathrm{~K}\right)$ of $3^{6+} \cdot 6 \mathrm{Cl}^{-}$. 


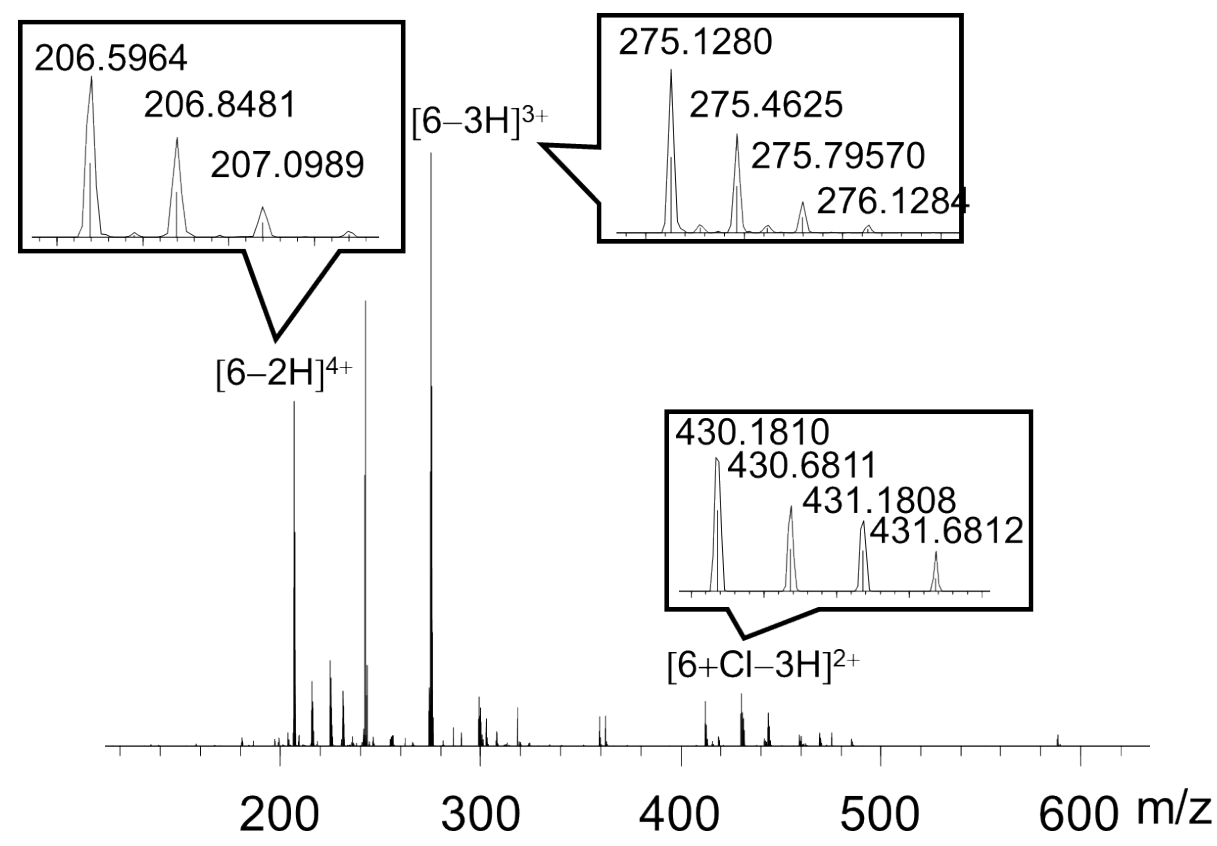

Figure S25. ESI-HRMS of $3^{6+} \cdot 6 \mathrm{Cl}^{-}$. The signals labeled in the spectrum correspond to molecular cations that contain four, three and two positive charges, respectively. These are formed presumably through either loss of protons or addition of $\mathrm{Cl}^{-}$counter anions.

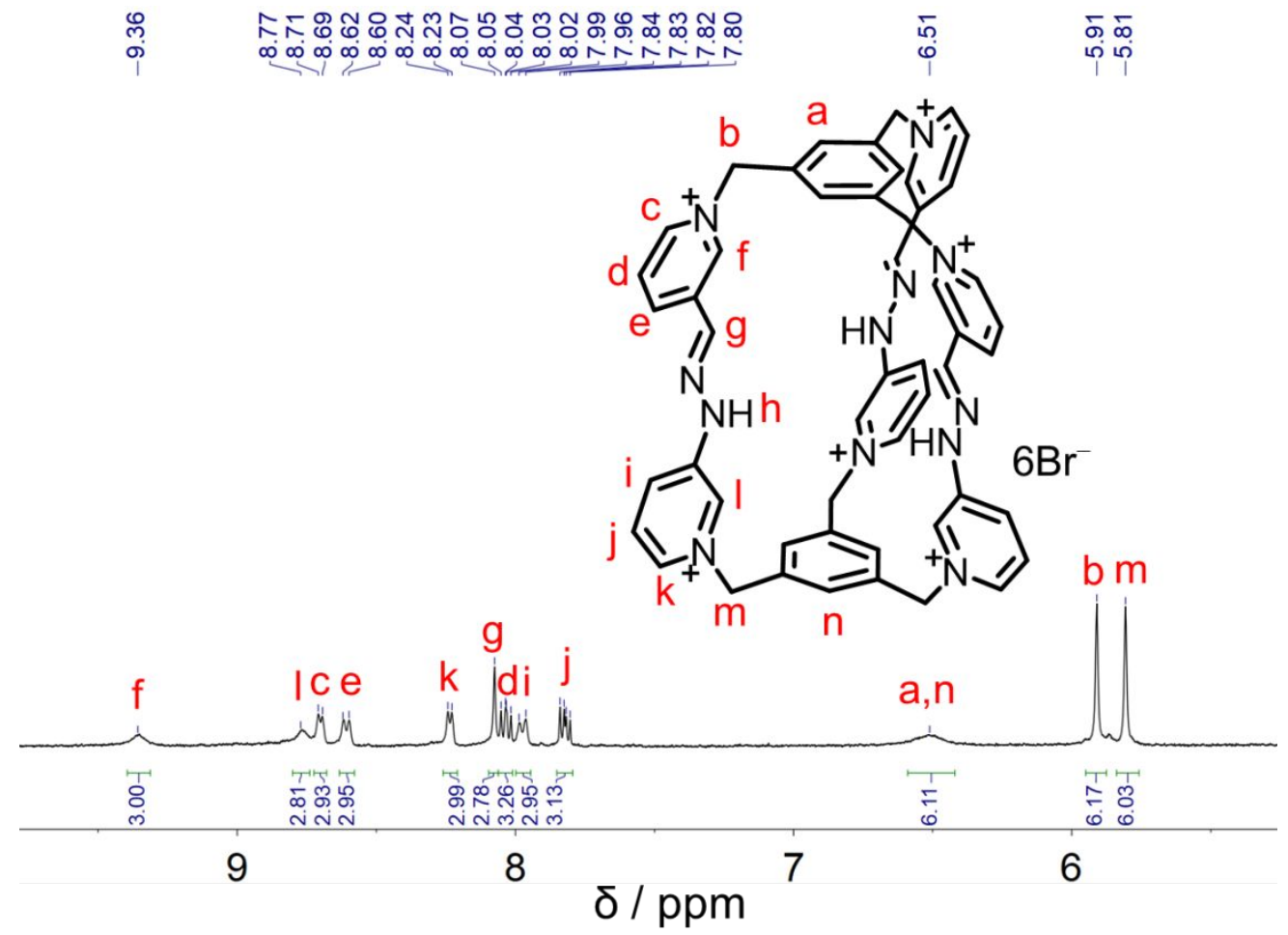

Figure S26. ${ }^{1} \mathrm{H}$ NMR spectrum $\left(400 \mathrm{MHz}, \mathrm{D}_{2} \mathrm{O}, 298 \mathrm{~K}\right)$ of $3^{6+} \cdot 6 \mathrm{Br}^{-}$. 


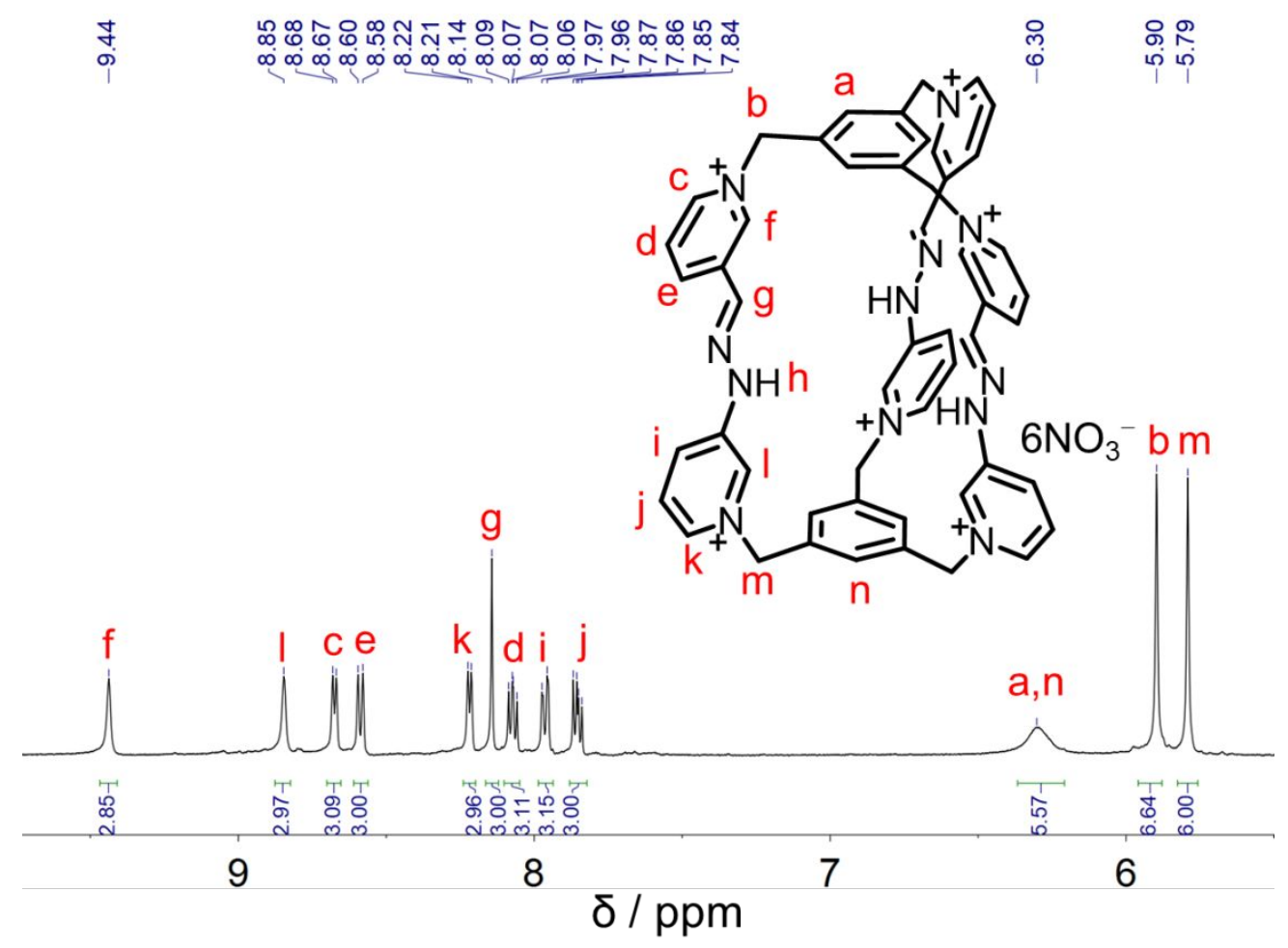

Figure S27. ${ }^{1} \mathrm{H}$ NMR spectrum $\left(500 \mathrm{MHz}, \mathrm{D}_{2} \mathrm{O}, 298 \mathrm{~K}\right)$ of $3^{6+} \cdot 6 \mathrm{NO}_{3}{ }^{-}$.

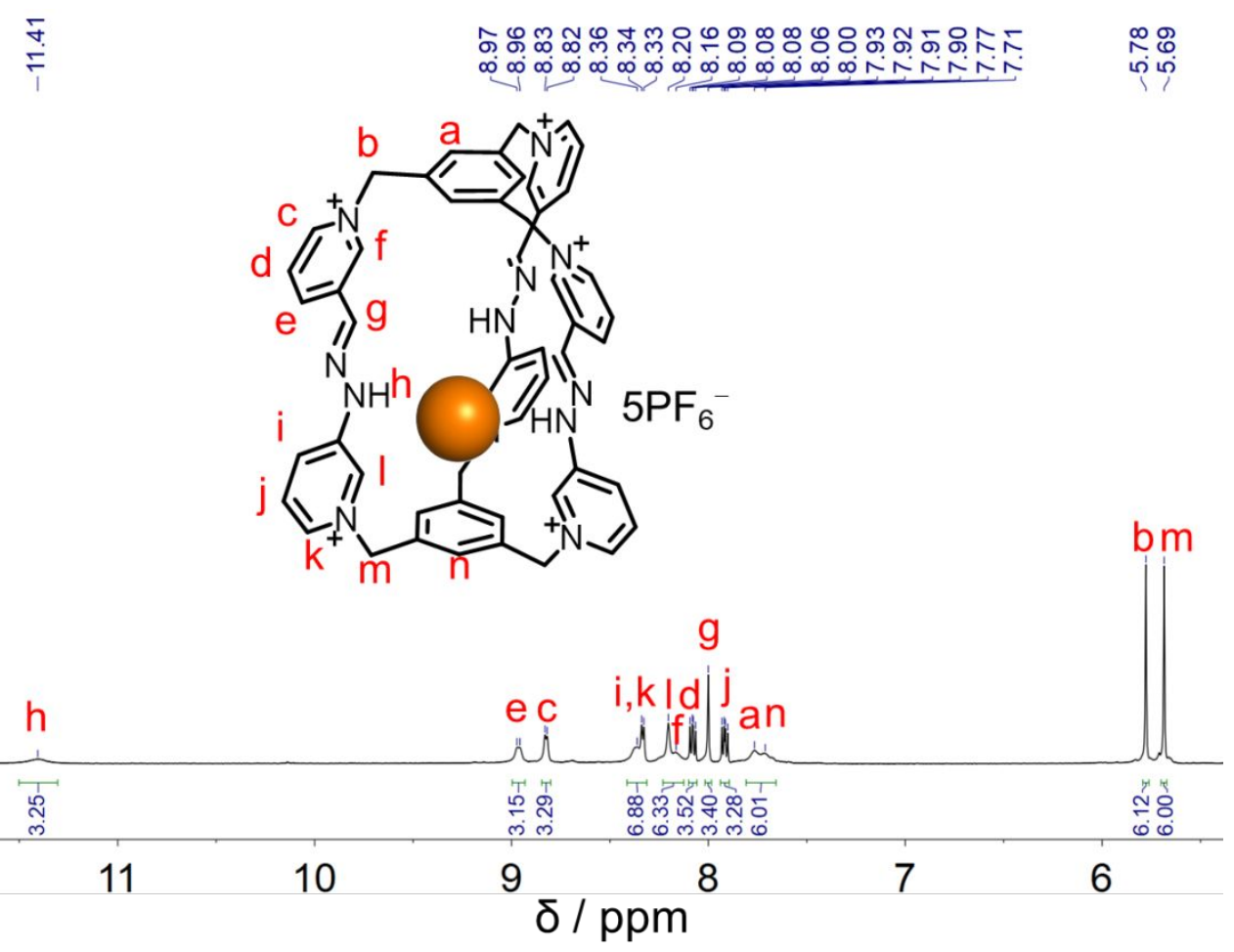

Figure S28. ${ }^{1} \mathrm{H}$ NMR spectrum $\left(500 \mathrm{MHz}, \mathrm{CD}_{3} \mathrm{CN}, 298 \mathrm{~K}\right)$ of $\mathrm{Br}^{-} \subset 3^{6+} \cdot 5 \mathrm{PF}_{6}{ }^{-}$. 
$\stackrel{\substack{1 \\ \infty}}{\stackrel{1}{1}}$
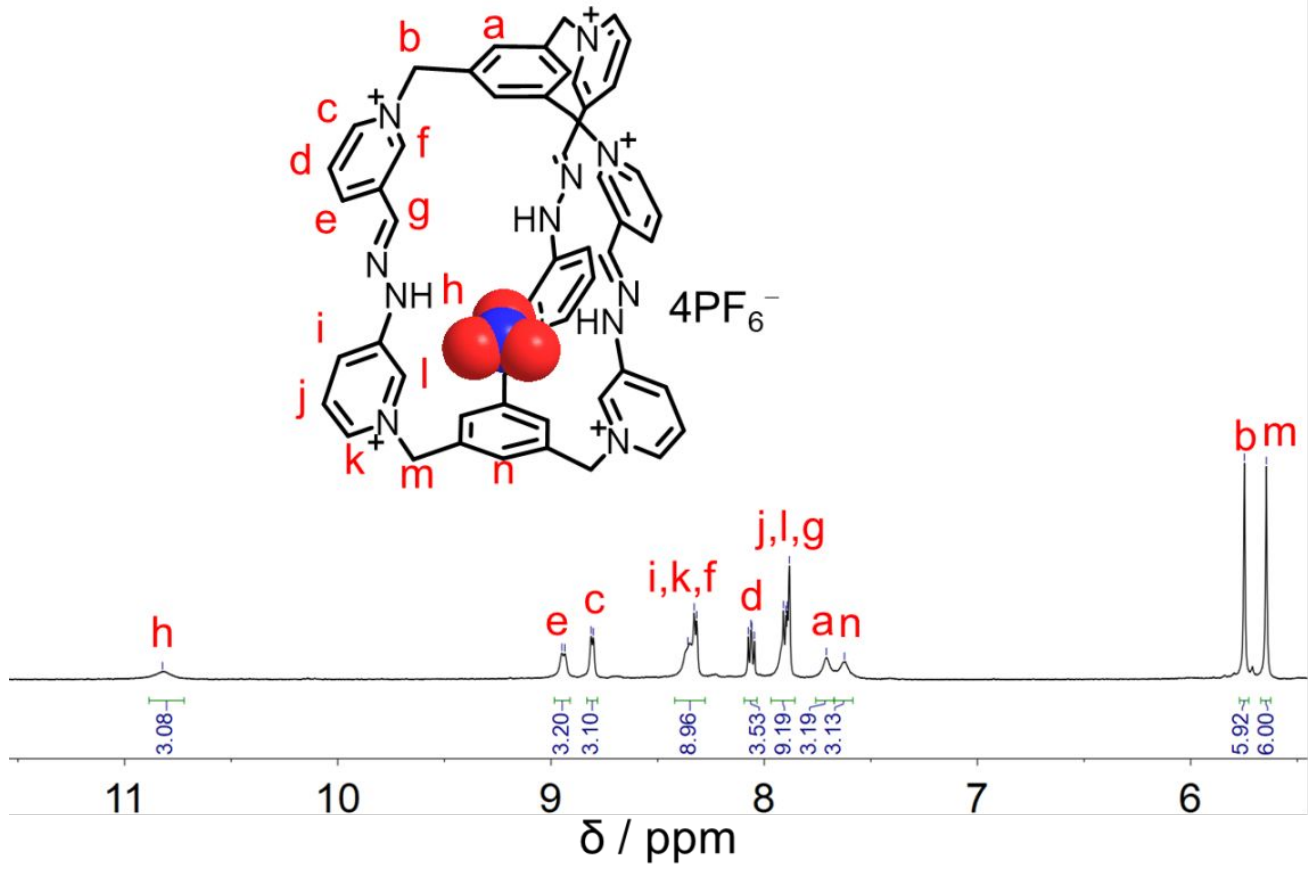

Figure S29. ${ }^{1} \mathrm{H}$ NMR spectrum $\left(500 \mathrm{MHz}, \mathrm{CD}_{3} \mathrm{CN}, 298 \mathrm{~K}\right)$ of $\mathrm{NO}_{3}{ }^{-} \subset 3^{6+} \cdot 5 \mathrm{PF}_{6}{ }^{-}$.
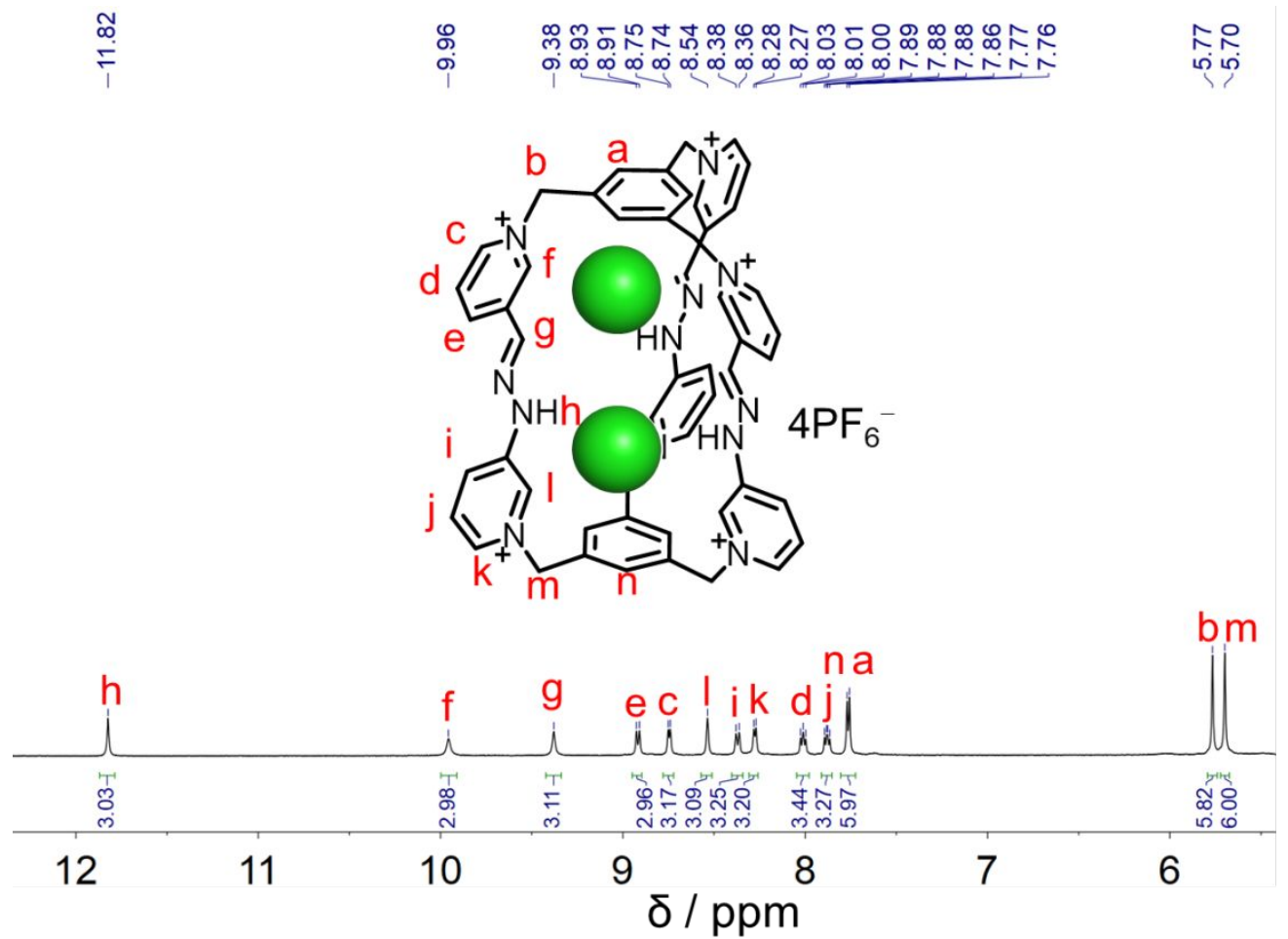

Figure S30. ${ }^{1} \mathrm{H}$ NMR spectrum $\left(500 \mathrm{MHz}, \mathrm{CD}_{3} \mathrm{CN}, 298 \mathrm{~K}\right)$ of $\left(\mathrm{Cl}^{-}\right)_{2} \subset 3^{6+} \cdot 4 \mathrm{PF}_{6}-$. 


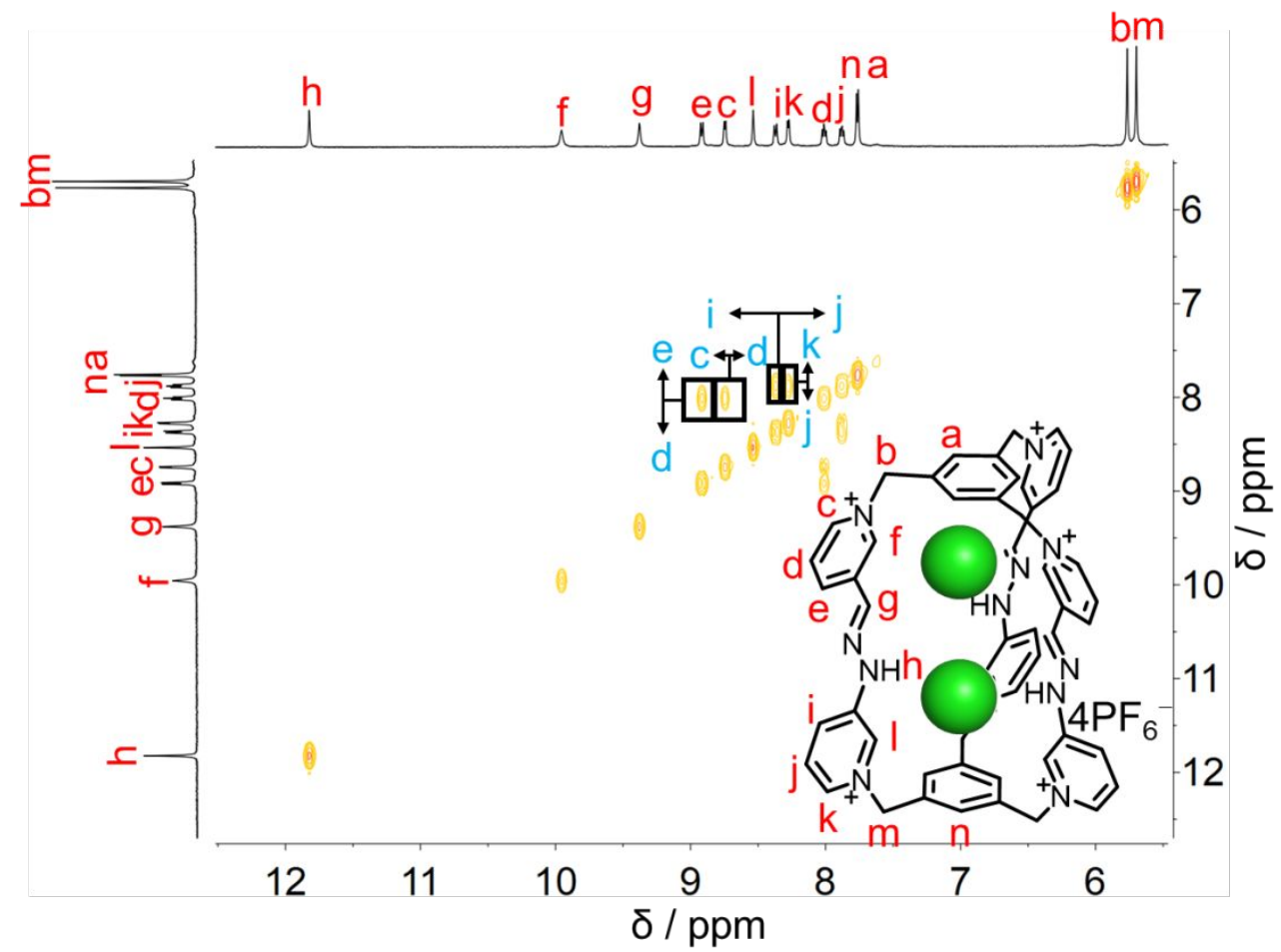

Figure S31. ${ }^{1} \mathrm{H}-{ }^{1} \mathrm{H}$ COSY spectrum $\left(500 \mathrm{MHz}, \mathrm{CD}_{3} \mathrm{CN}, 298 \mathrm{~K}\right)$ of $\left(\mathrm{Cl}^{-}\right)_{2} \subset 3^{6+} \cdot 4 \mathrm{PF}_{6}{ }^{-}$.

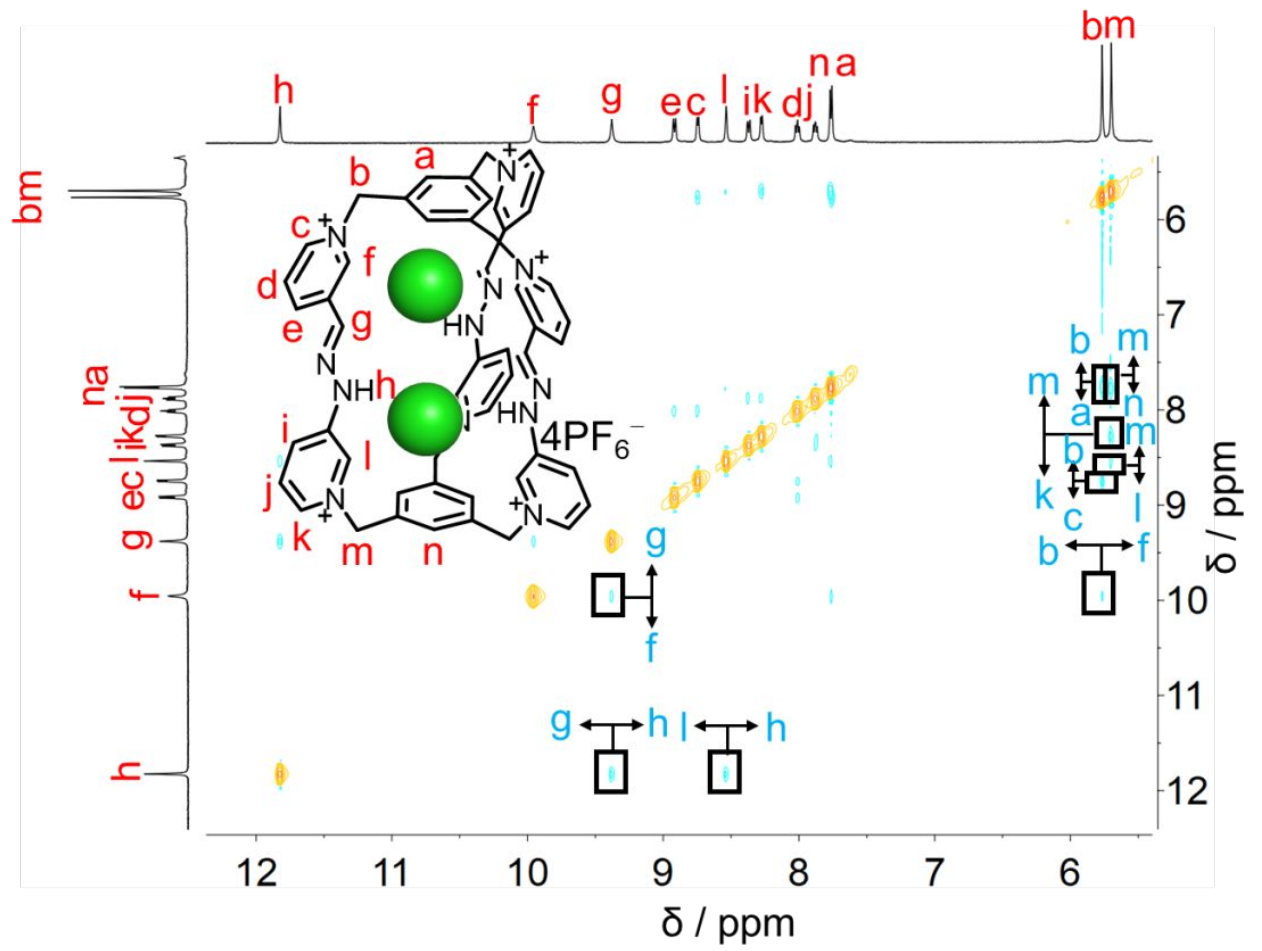

Figure S32. ${ }^{1} \mathrm{H}-{ }^{1} \mathrm{H}$ NOESY spectrum $\left(500 \mathrm{MHz}, \mathrm{CD}_{3} \mathrm{CN}, 298 \mathrm{~K}\right)$ of $\left(\mathrm{Cl}^{-}\right)_{2} \subset 3^{6+} \cdot 4 \mathrm{PF}_{6}{ }^{-}$. 

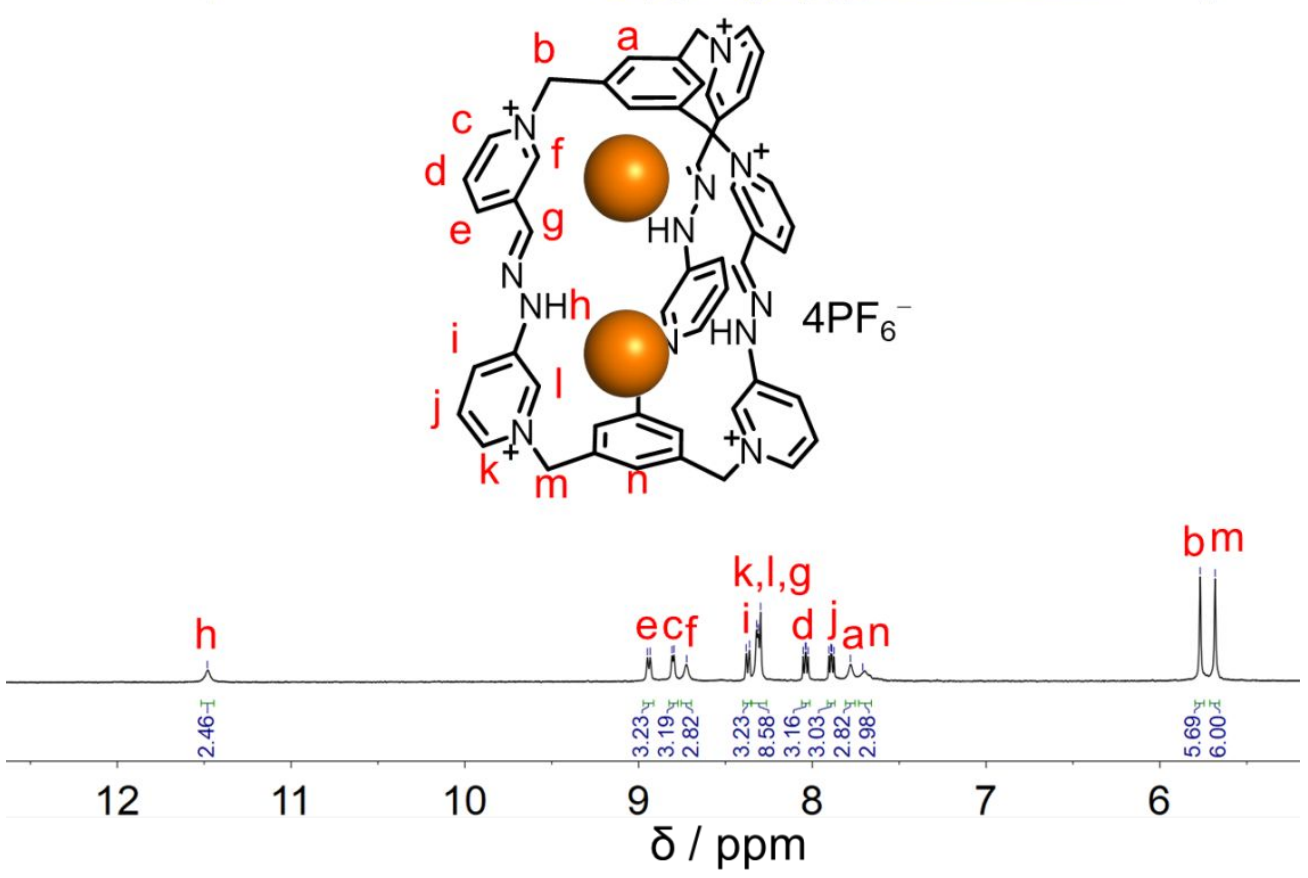

Figure S33. ${ }^{1} \mathrm{H}$ NMR spectrum $\left(500 \mathrm{MHz}, \mathrm{CD}_{3} \mathrm{CN}, 298 \mathrm{~K}\right)$ of $(\mathrm{Br})_{2} \subset 3^{6+} \cdot 4 \mathrm{PF}_{6}{ }^{-}$.

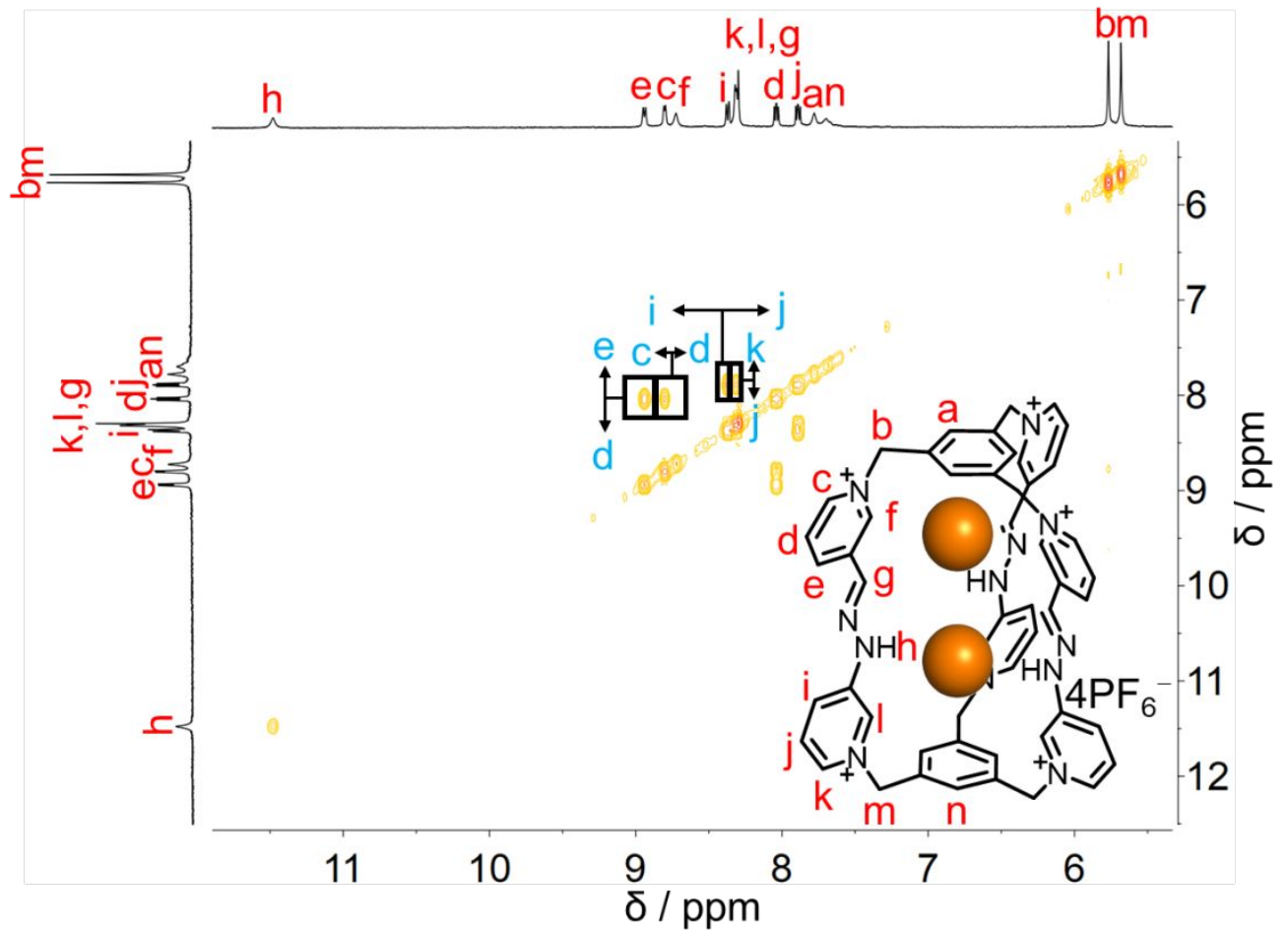

Figure S34. ${ }^{1} \mathrm{H}-{ }^{1} \mathrm{H}$ COSY spectrum $\left(500 \mathrm{MHz}, \mathrm{CD}_{3} \mathrm{CN}, 298 \mathrm{~K}\right)$ of $(\mathrm{Br})_{2} \subset 3^{6+} \cdot 4 \mathrm{PF}_{6}{ }^{-}$. 


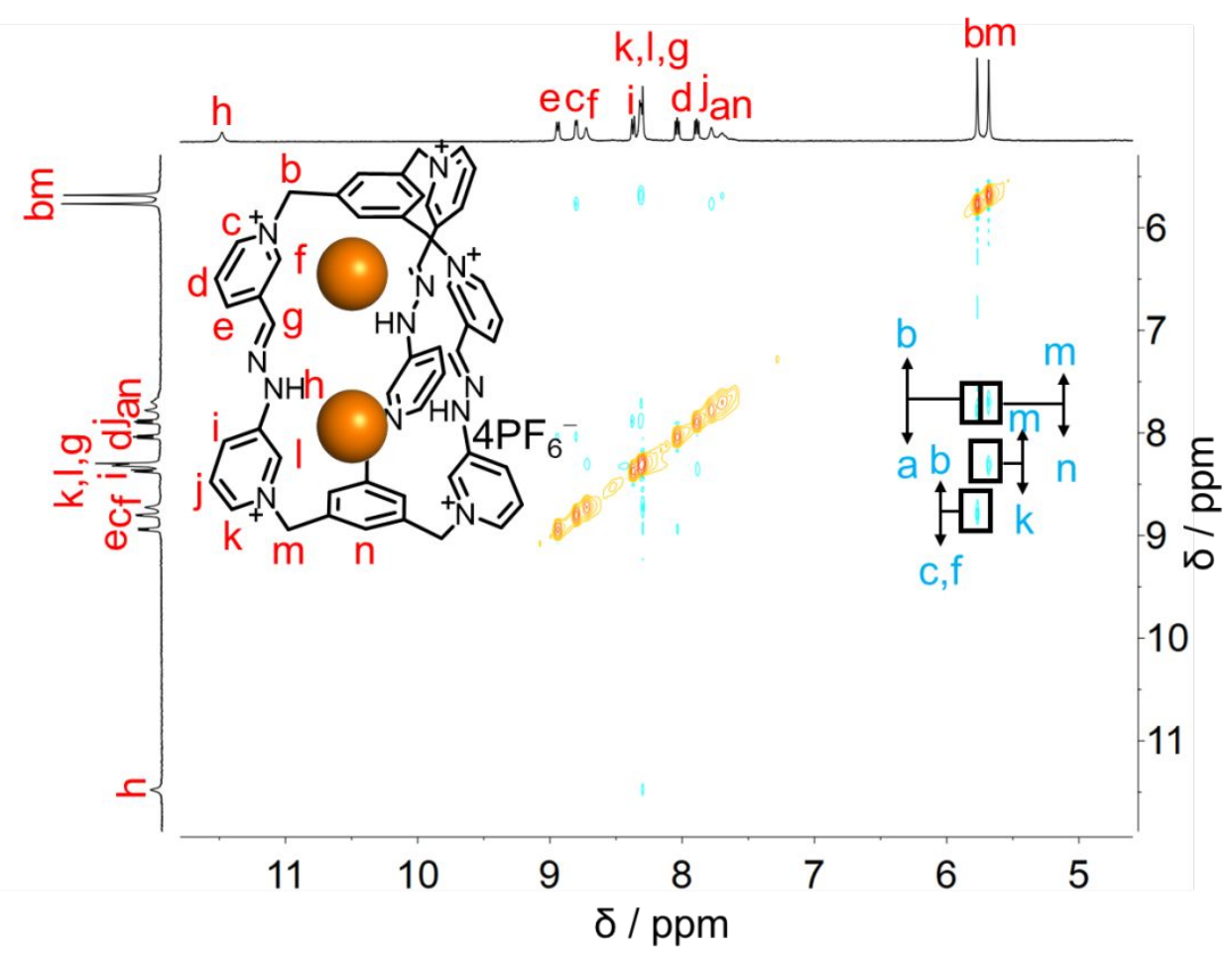

Figure S35. ${ }^{1} \mathrm{H}-{ }^{1} \mathrm{H}$ NOESY spectrum (500 MHz, $\mathrm{CD}_{3} \mathrm{CN}, 298 \mathrm{~K}$ ) of $\left(\mathrm{Br}^{-}\right)_{2} \subset 3^{6+} \cdot 4 \mathrm{PF}_{6}{ }^{-}$.

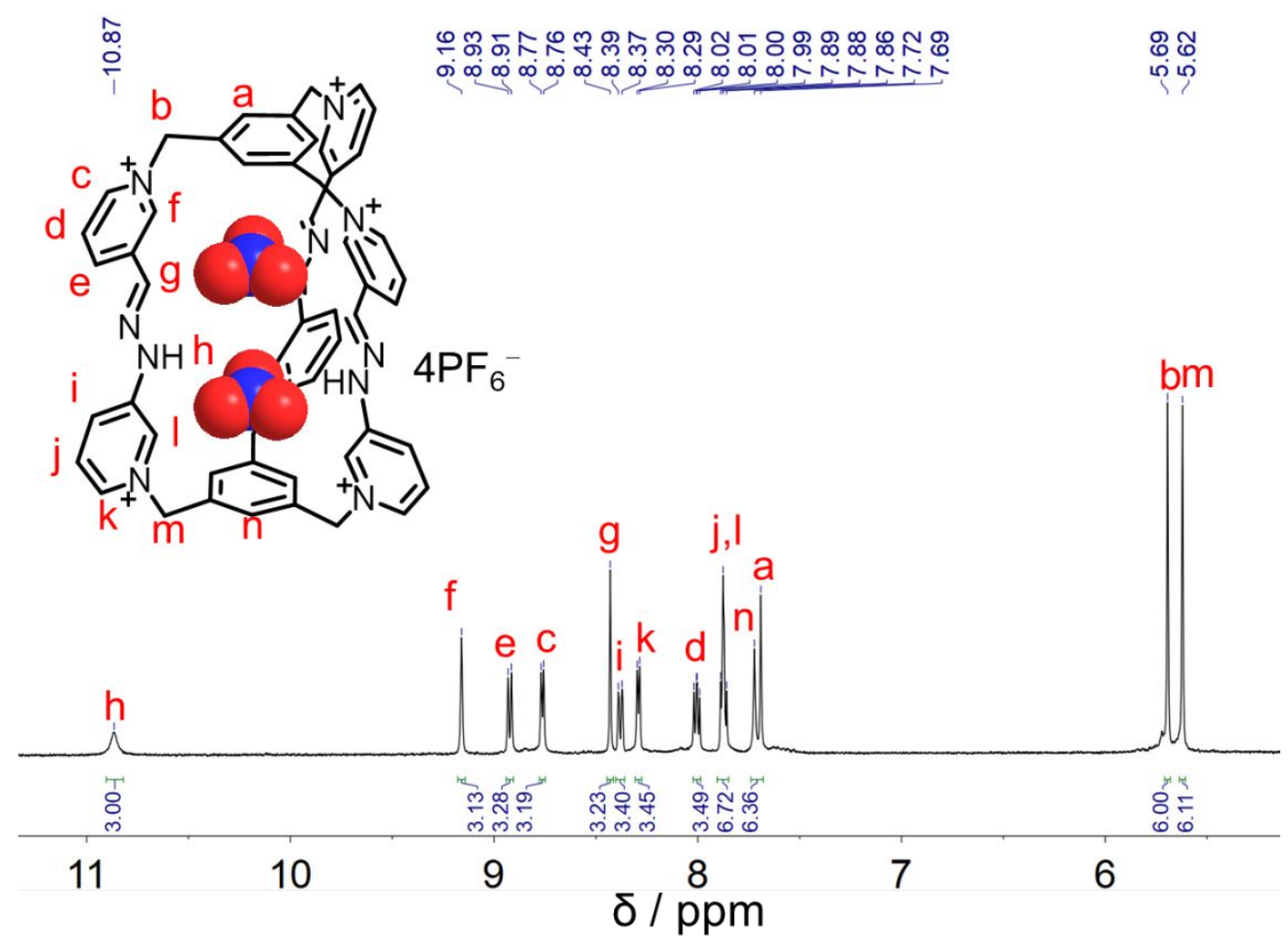

Figure S36. ${ }^{1} \mathrm{H}$ NMR spectrum $\left(500 \mathrm{MHz}, \mathrm{CD}_{3} \mathrm{CN}, 298 \mathrm{~K}\right)$ of $\left(\mathrm{NO}_{3}{ }^{-}\right)_{2} \subset 3^{6+} \cdot 4 \mathrm{PF}_{6}{ }^{-}$. 


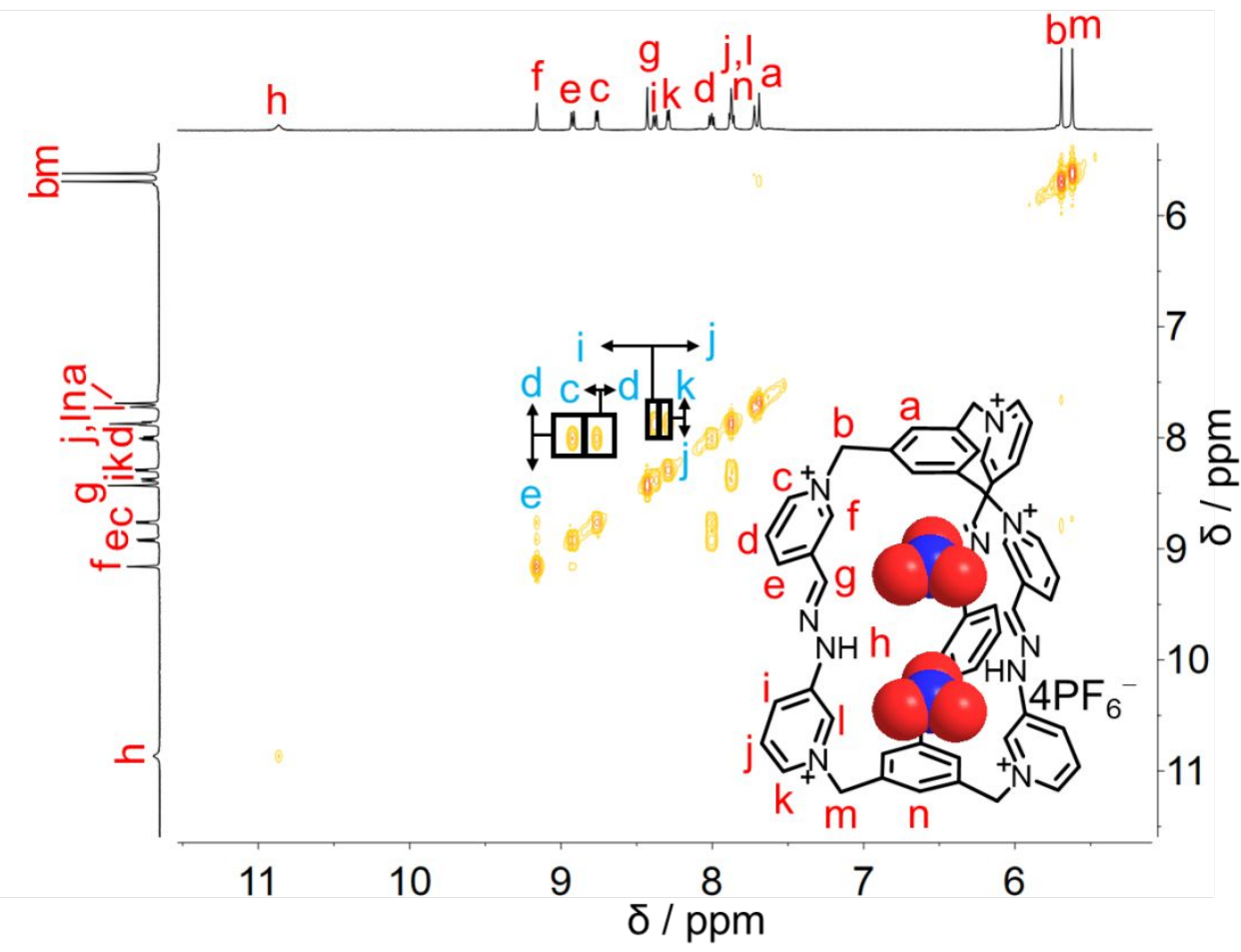

Figure S37. ${ }^{1} \mathrm{H}-{ }^{1} \mathrm{H}$ COSY spectrum $\left(500 \mathrm{MHz}, \mathrm{CD}_{3} \mathrm{CN}, 298 \mathrm{~K}\right)$ of $\left(\mathrm{NO}_{3}{ }^{-}\right)_{2} \subset 3^{6+} \cdot 4 \mathrm{PF}_{6}{ }^{-}$.

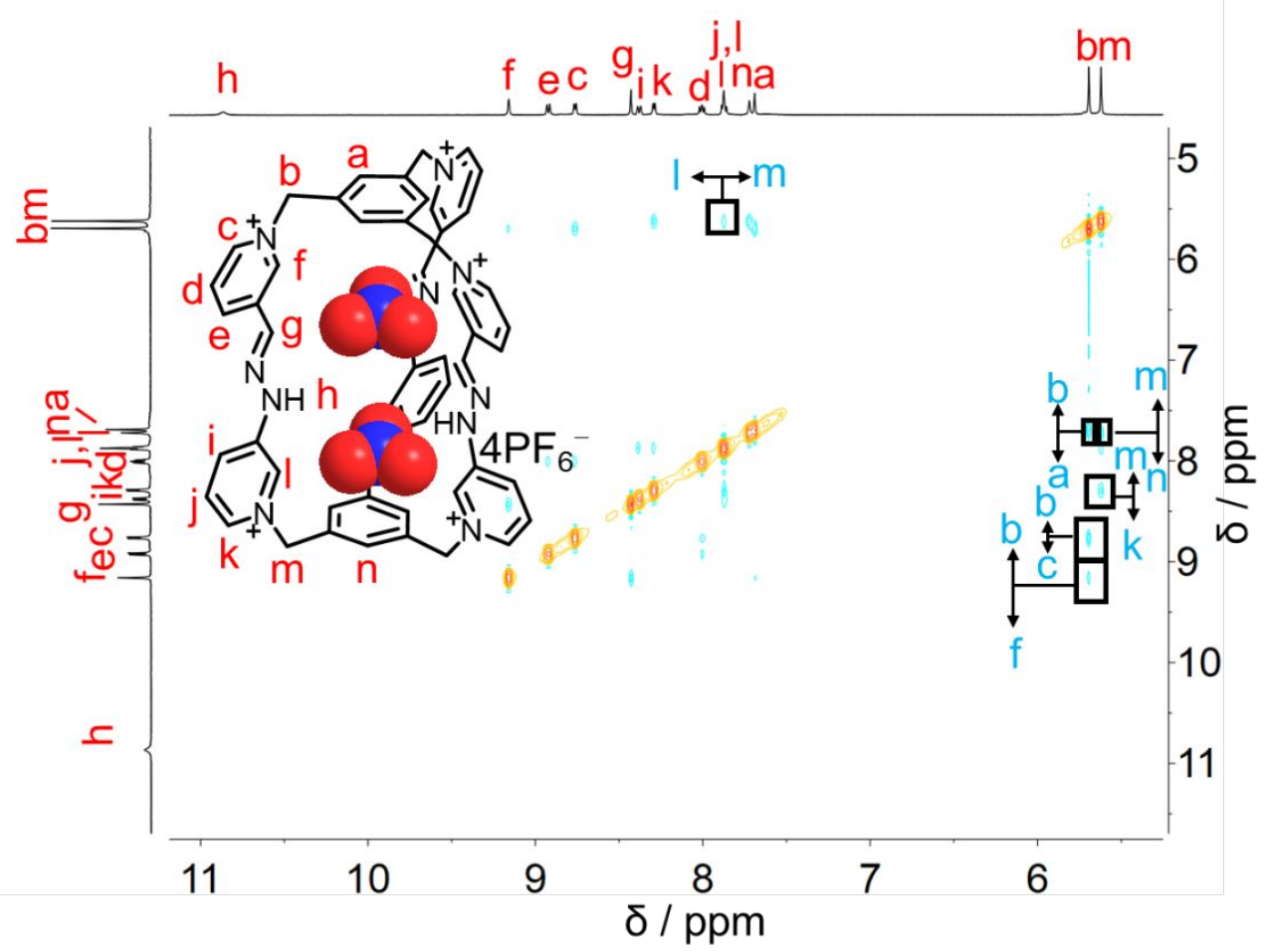

Figure S38. ${ }^{1} \mathrm{H}-{ }^{1} \mathrm{H}$ NOESY spectrum $\left(500 \mathrm{MHz}, \mathrm{CD}_{3} \mathrm{CN}, 298 \mathrm{~K}\right)$ of $\left(\mathrm{NO}_{3}{ }^{-}\right)_{2} \subset 3^{6+} \cdot 4 \mathrm{PF}_{6}{ }^{-}$. 


\section{Guest recognition by $3^{6+}$}

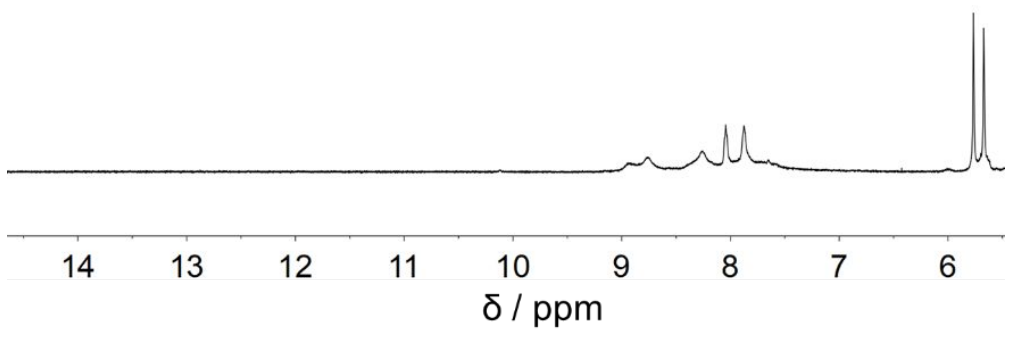

Figure 39. Partial ${ }^{1} \mathrm{H}$ NMR spectra $\left(600 \mathrm{MHz}, \mathrm{CD}_{3} \mathrm{CN}, 298 \mathrm{~K}\right)$ of $3^{6+} \cdot 6 \mathrm{PF}_{6}{ }^{-}$recorded after the addition of 1.0 equiv. $\mathrm{TBA}^{+} \cdot \mathrm{CH}_{3} \mathrm{COO}^{-}$.

Addition of one equiv. $\mathrm{TBA}^{+\cdot} \mathrm{CH}_{3} \mathrm{COO}^{-}$into a $\mathrm{CD}_{3} \mathrm{CN}$ solution of $3^{6+} \cdot 6 \mathrm{PF}_{6}{ }^{-}$, led to disappearance of the $\mathrm{NH}$ resonance, a finding ascribed to deprotonation.

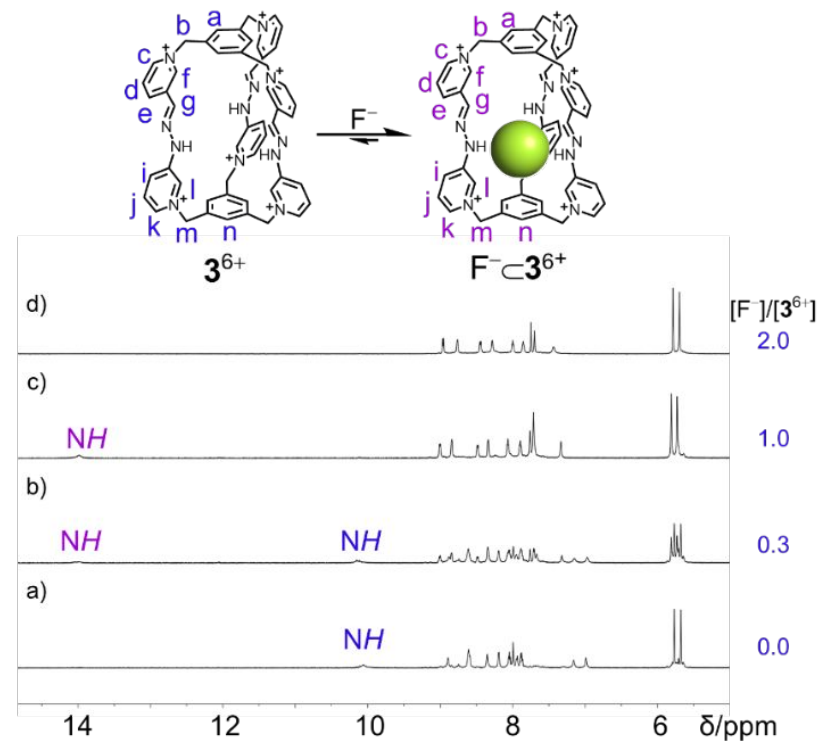

Figure 40. Partial ${ }^{1} \mathrm{H}$ NMR spectra $\left(600 \mathrm{~Hz}, 298 \mathrm{~K}, \mathrm{CD}_{3} \mathrm{CN}\right)$ of $3^{6+} \cdot 6 \mathrm{PF}_{6}{ }^{-}$a) before and after adding b) 0.3 , c) 1.0 and d) 2.0 equiv. of tetrabutylammonium fluoride $\left(\mathrm{TBA}^{+} \cdot \mathrm{F}^{-}\right)$.

Upon addition of $\mathrm{TBA}^{+} \cdot \mathrm{F}^{-}$, e.g., 0.3 equiv., the $\mathrm{NH}$ resonance at $10 \mathrm{ppm}$ decreases in intensity (Figure 40b), while a resonance at $14 \mathrm{ppm}$, corresponding to the $\mathrm{NH}$ protons in the complex $\mathrm{F}^{-} \subset 3^{6+}$, appears. The observation that the $\mathrm{NH}$ protons have two separated resonances before and after adding $\mathrm{F}^{-}$is interpreted in terms of $\mathrm{F}^{-} \subset 3^{6+}$ undergoing slow host-guest exchange on the ${ }^{1} \mathrm{H}$ NMR timescale. Further addition of $\mathrm{TBA}^{+} \cdot \mathrm{F}^{-}$led to loss of the $\mathrm{NH}$ resonance, indicating that $\mathrm{NH}$ protons were deprotonated by $\mathrm{F}^{-}$anions. 


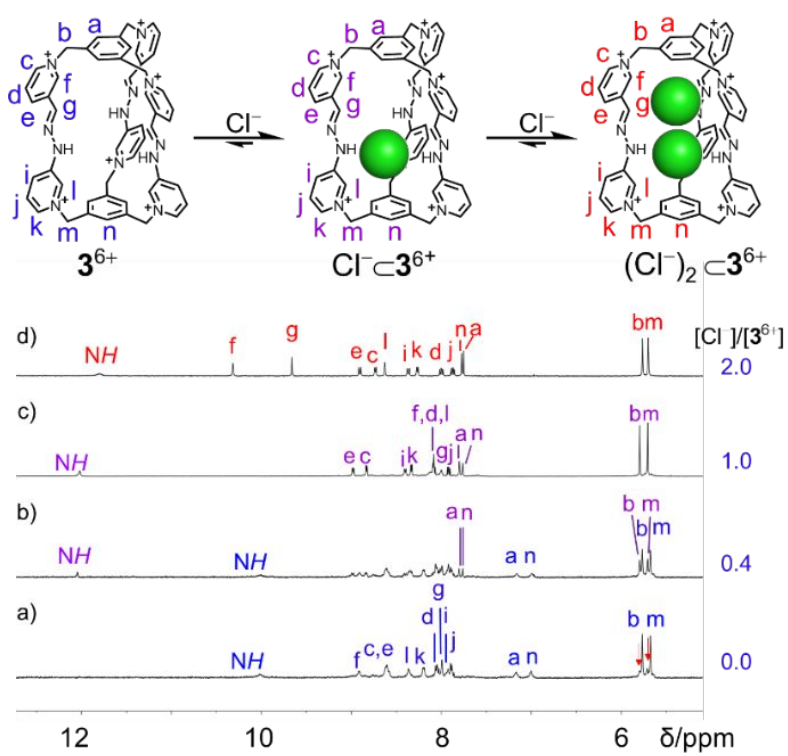

Figure S41. Partial ${ }^{1} \mathrm{H}$ NMR spectra $\left(400 \mathrm{~Hz}, 298 \mathrm{~K}, \mathrm{CD}_{3} \mathrm{CN}\right)$ of $3^{6+} \cdot 6 \mathrm{PF}_{6}{ }^{-}$recorded a) before and after adding b) 0.4 , c) 1.0 and d) 2.0 equiv. of tetrabutylammonium chloride $\left(\mathrm{TBA}^{+} \cdot \mathrm{Cl}^{-}\right)$. Note: Before adding $\mathrm{TBA}^{+} \cdot \mathrm{Cl}^{-}$, the sample considered to be $3^{6+} \cdot 6 \mathrm{PF}_{6}{ }^{-}$contains small amount of $\mathrm{Cl}^{-} \subset 3^{6+} \cdot 5 \mathrm{PF}_{6}$; some of the resonances are labelled with red arrows.
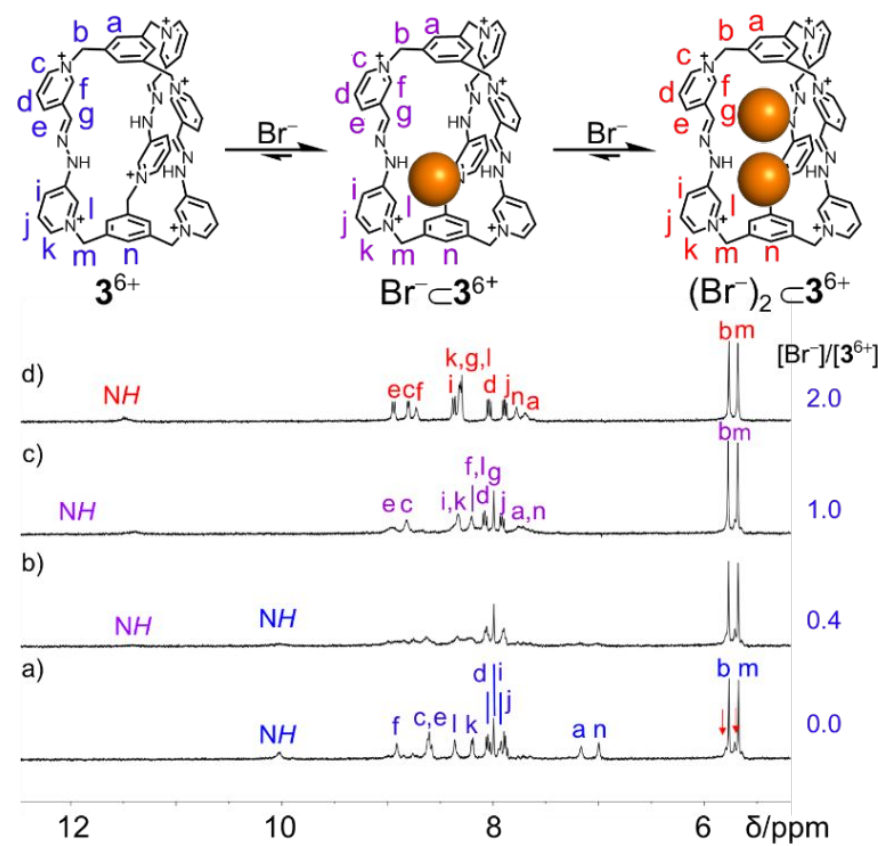

Figure S42. Partial ${ }^{1} \mathrm{H}$ NMR spectra $\left(400 \mathrm{~Hz}, 298 \mathrm{~K}, \mathrm{CD}_{3} \mathrm{CN}\right)$ of $3^{6+} \cdot 6 \mathrm{PF}_{6}{ }^{-}$a) before and after adding b) 0.4 , c) 1.0 and d) 2.0 equiv. of tetrabutylammonium bromide $\left(\mathrm{TBA}^{+} \cdot \mathrm{Br}^{-}\right)$. Note: Before adding $\mathrm{TBA}^{+} \cdot \mathrm{Br}^{-}$, the sample considered to be $3^{6+} \cdot 6 \mathrm{PF}_{6}{ }^{-}$contains small amount of $\mathrm{Cl}^{-} \subset 3^{6+} .5 \mathrm{PF}_{6}{ }^{-}$(cf. red arrows). 

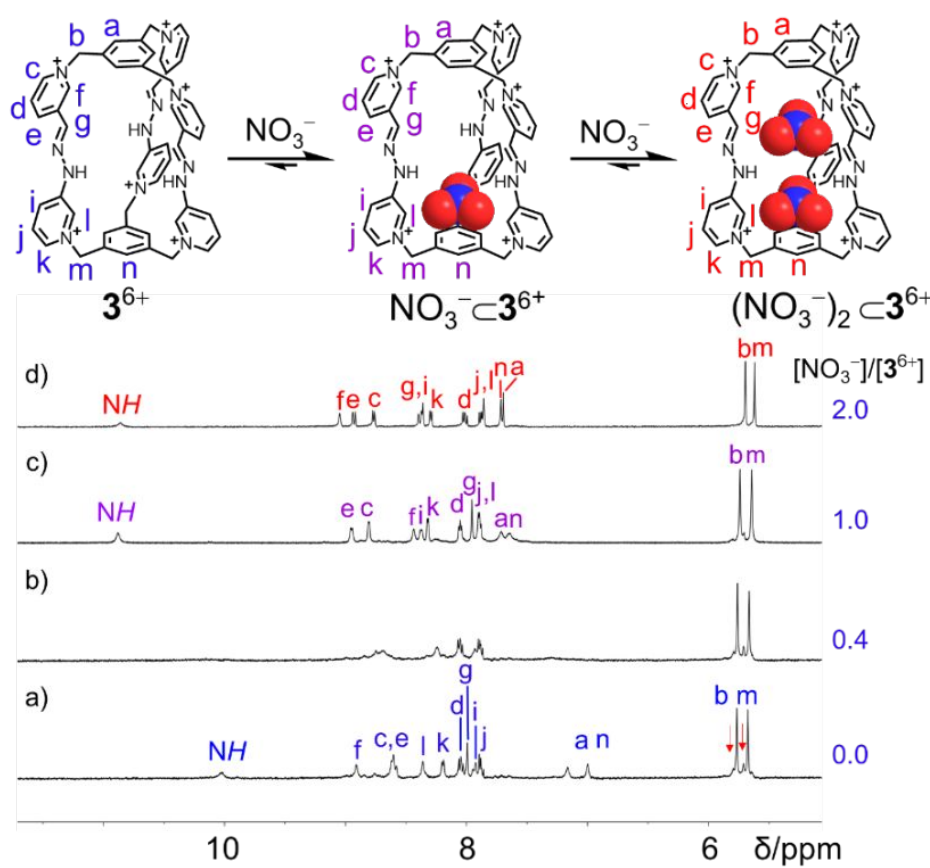

Figure S43. Partial ${ }^{1} \mathrm{H}$ NMR spectra $\left(400 \mathrm{~Hz}, 298 \mathrm{~K}, \mathrm{CD}_{3} \mathrm{CN}\right)$ of $3^{6+} \cdot 6 \mathrm{PF}_{6}{ }^{-}$a) before and after adding b) 0.4 , c) 1.0 and d) 2.0 equiv. of tetrabutylammonium nitrate $\left(\mathrm{TBA}^{+} \cdot \mathrm{NO}_{3}{ }^{-}\right)$. Note: Before adding $\mathrm{TBA}^{+} \cdot \mathrm{NO}_{3}{ }^{-}$, the sample considered to be $3^{6+} \cdot 6 \mathrm{PF}_{6}{ }^{-}$contains small amount of $\mathrm{Cl}^{-} \subset 3^{6+} \cdot 5 \mathrm{PF}_{6}{ }^{-}$; some of the resonances are labelled with red arrows.
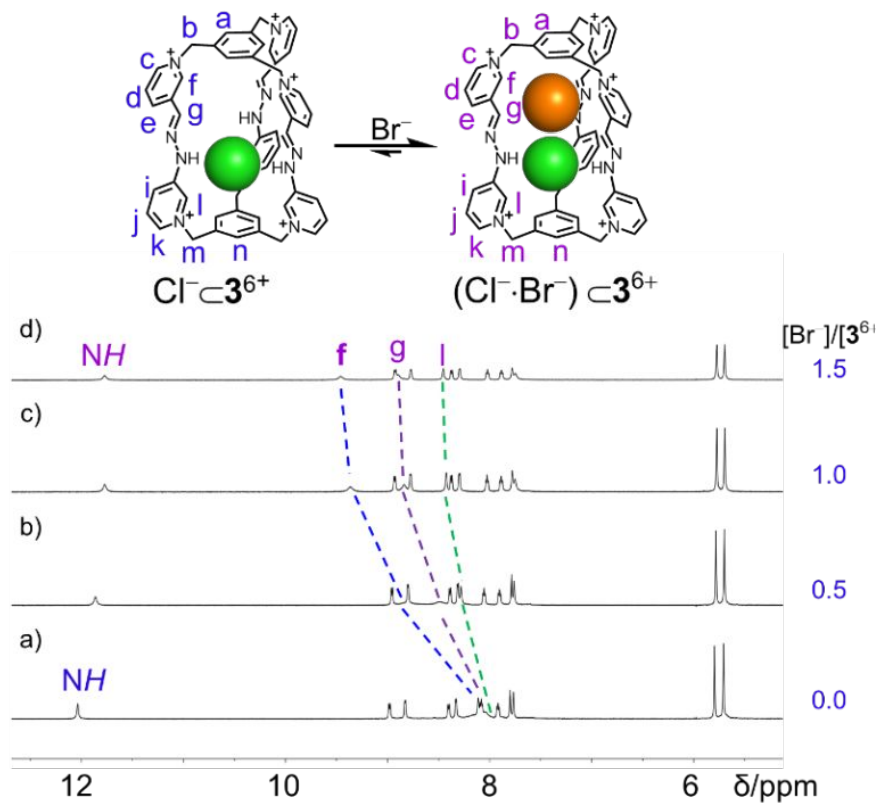

Figure S44. Partial ${ }^{1} \mathrm{H}$ NMR spectra $\left(600 \mathrm{MHz}, 298 \mathrm{~K}, \mathrm{CD}_{3} \mathrm{CN}\right)$ of $\mathrm{Cl}^{-} \subset 3^{6+}$ a) before and after adding b) 0.5 , c) 1.0 and d) 1.5 equiv. of tetrabutylammonium bromide $\left(\mathrm{TBA}^{+} \cdot \mathrm{Br}\right)$. 


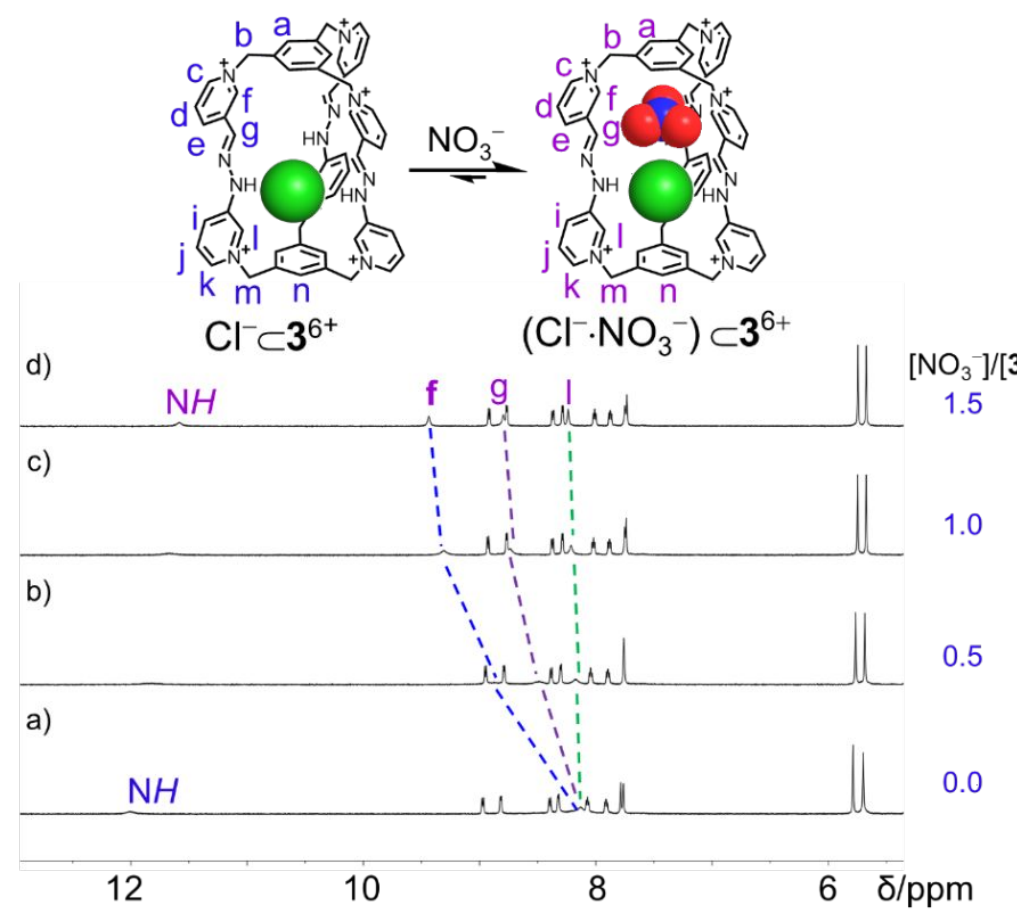

Figure S45. Partial ${ }^{1} \mathrm{H}$ NMR spectra $\left(600 \mathrm{MHz}, 298 \mathrm{~K}, \mathrm{CD}_{3} \mathrm{CN}\right)$ of $\mathrm{Cl}^{-} \subset \mathbf{3}^{6+}$ a) before and after adding b) 0.5 , c) 1.0 and d) 1.5 equiv. of tetrabutylammonium nitrate $\left(\mathrm{TBA}^{+} \cdot \mathrm{NO}_{3}{ }^{-}\right)$.
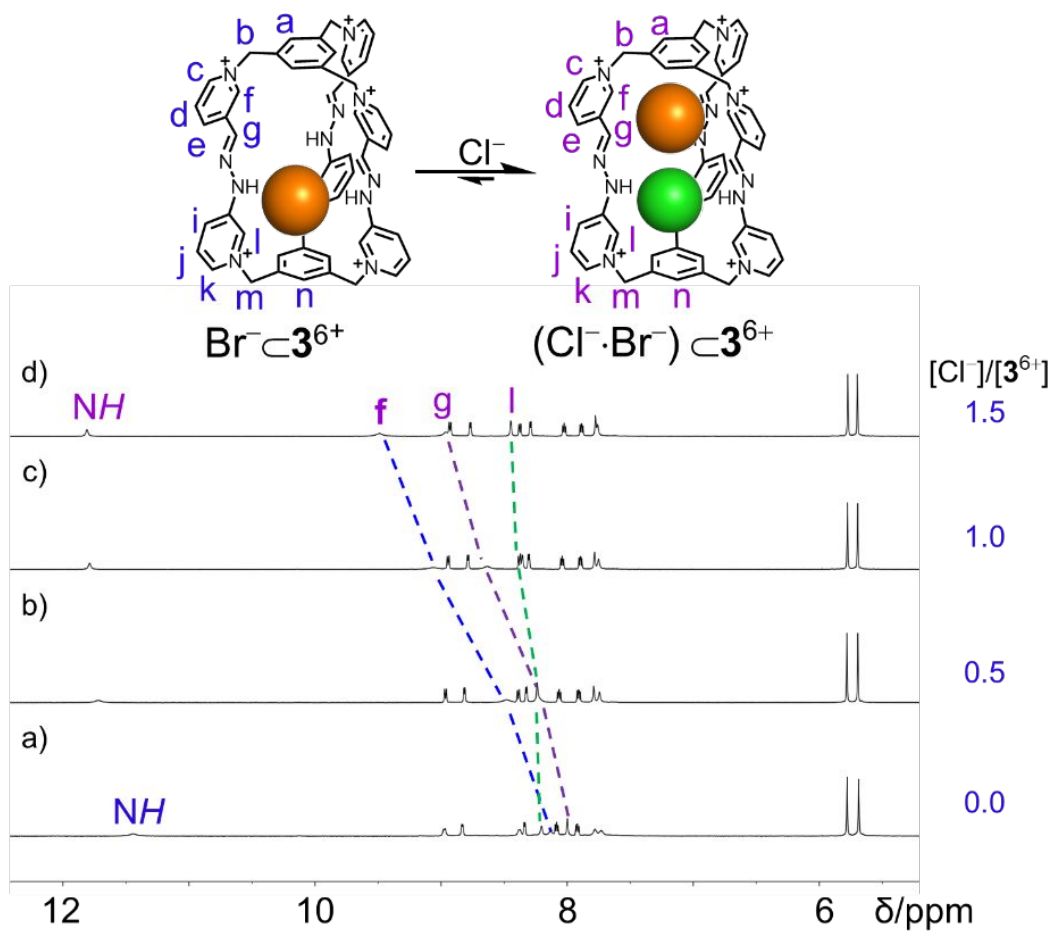

Figure S46. Partial ${ }^{1} \mathrm{H}$ NMR spectra $\left(600 \mathrm{MHz}, 298 \mathrm{~K}, \mathrm{CD}_{3} \mathrm{CN}\right)$ of $\mathrm{Br}^{-} \subset 3^{6+}$ a) before and after adding b) $0.5, \mathrm{c}) 1.0$ and d) 1.5 equiv. of tetrabutylammonium chloride $\left(\mathrm{TBA}^{+} \cdot \mathrm{Cl}^{-}\right)$. 

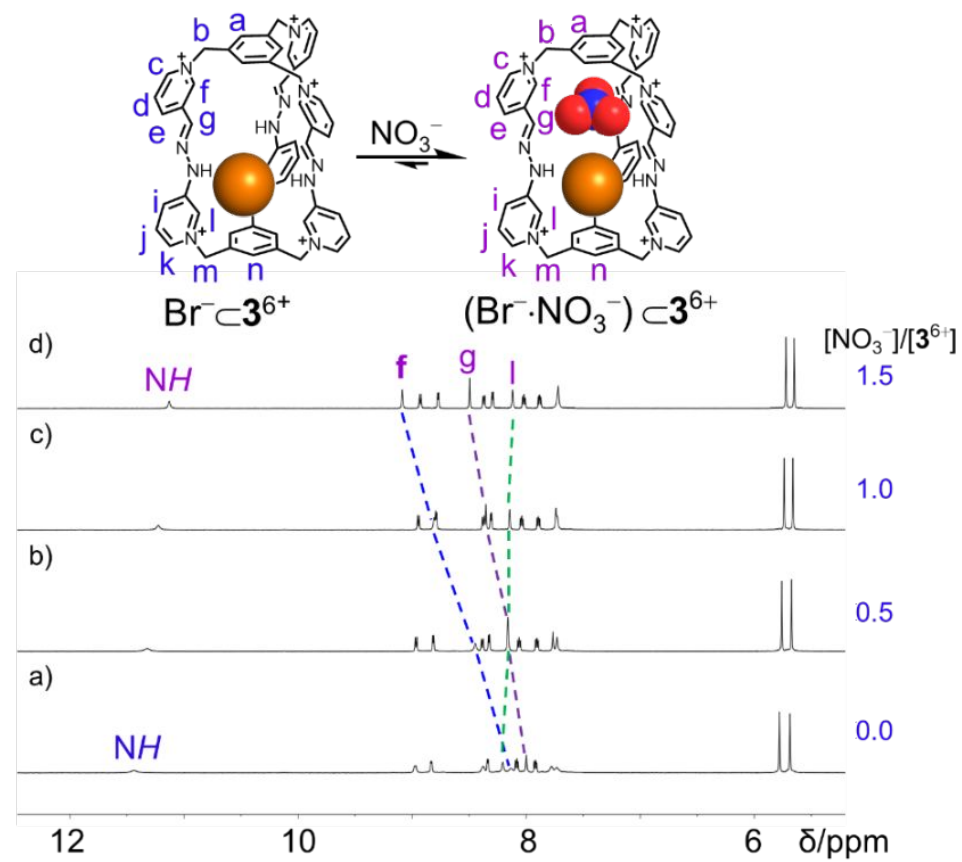

Figure S47. Partial ${ }^{1} \mathrm{H}$ NMR spectra $\left(600 \mathrm{MHz}, 298 \mathrm{~K}, \mathrm{CD}_{3} \mathrm{CN}\right)$ of $\mathrm{Br}^{-} \subset 3^{6+}$ a) before and after adding b) 0.5 , c) 1.0 and d) 1.5 equiv. of tetrabutylammonium nitrate $\left(\mathrm{TBA}^{+} \cdot \mathrm{NO}_{3}{ }^{-}\right)$.
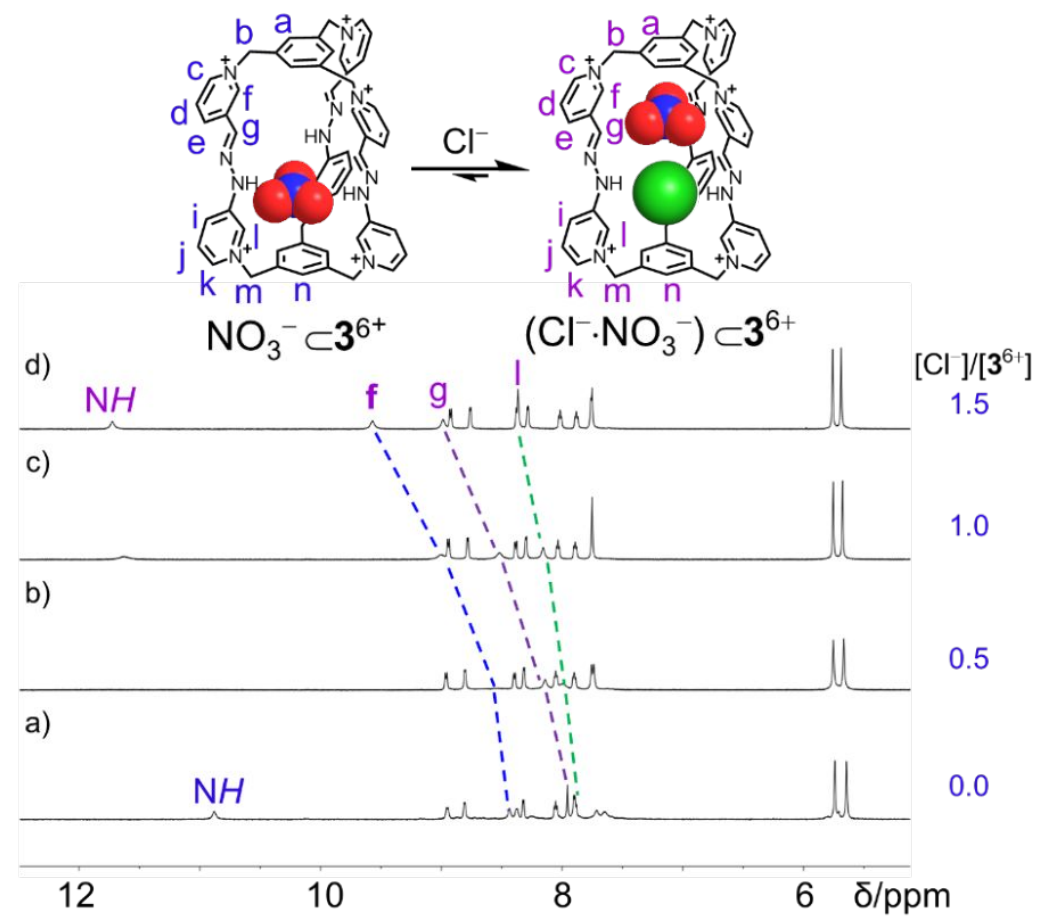

Figure S48. Partial ${ }^{1} \mathrm{H}$ NMR spectra (600 MHz, $\left.298 \mathrm{~K}, \mathrm{CD}_{3} \mathrm{CN}\right)$ of $\mathrm{NO}_{3}{ }^{-} \subset 3^{6+}$ a) before and after adding b) $0.5, \mathrm{c}) 1.0$ and d) 1.5 equiv. of tetrabutylammonium chloride $\left(\mathrm{TBA}^{+} \cdot \mathrm{Cl}^{-}\right)$. 

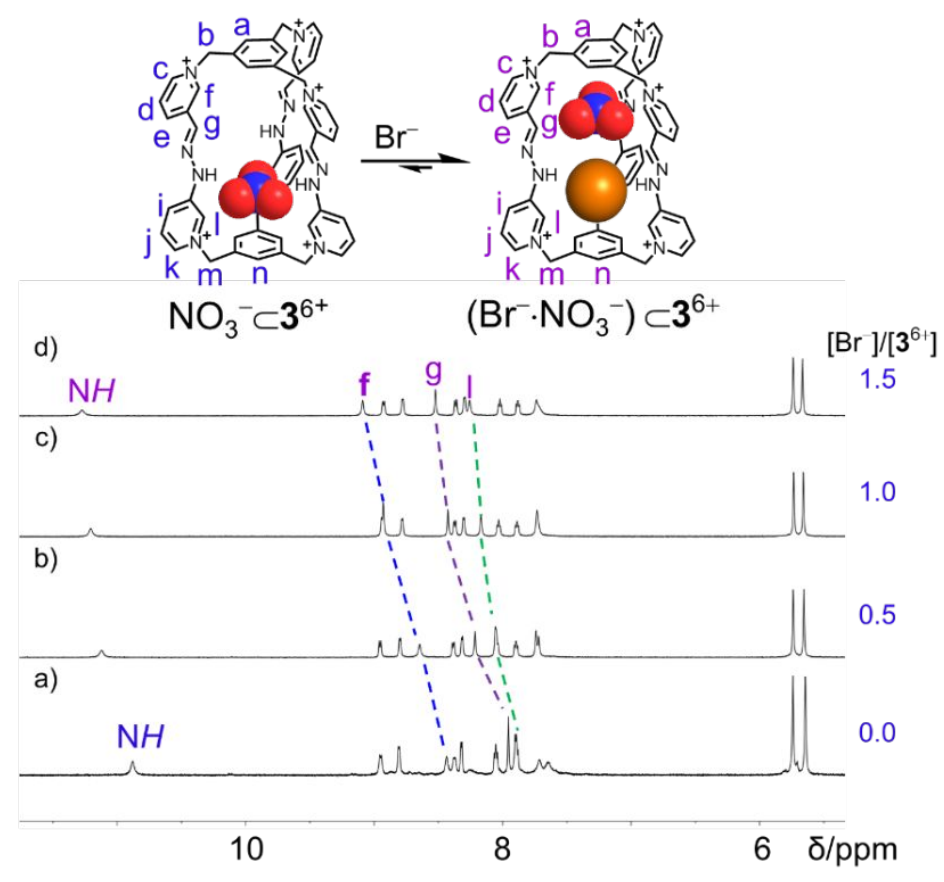

Figure S49. Partial ${ }^{1} \mathrm{H}$ NMR spectra $\left(600 \mathrm{MHz}, 298 \mathrm{~K}, \mathrm{CD}_{3} \mathrm{CN}\right)$ of $\mathrm{NO}_{3}{ }^{-} \subset 3^{6+}$ a) before and after adding b) $0.5, \mathrm{c}) 1.0$ and d) 1.5 equiv. of tetrabutylammonium bromide $\left(\mathrm{TBA}^{+} \cdot \mathrm{Br}\right)$.
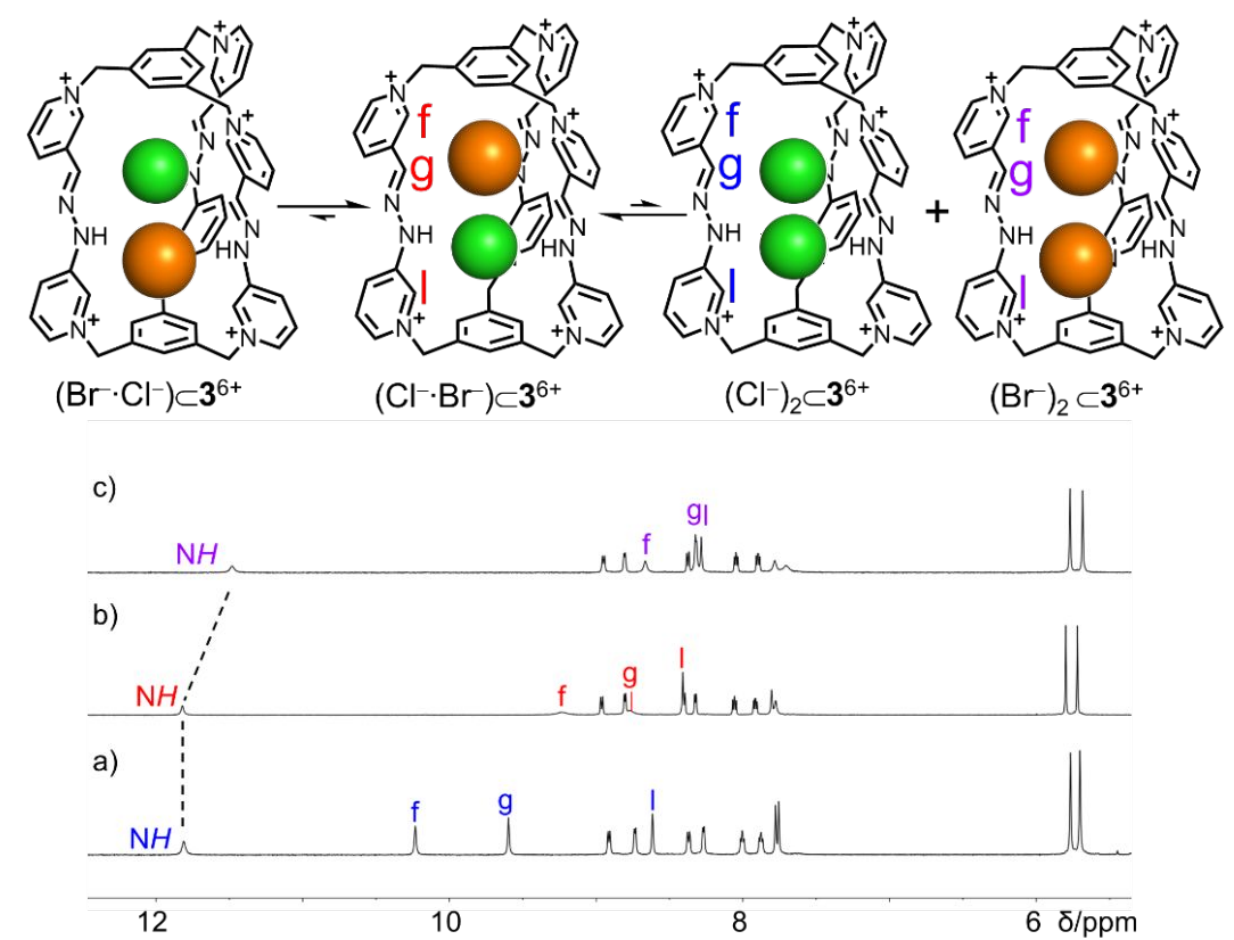

Figure 50. Partial ${ }^{1} \mathrm{H}$ NMR spectra $\left(298 \mathrm{~K}, \mathrm{CD}_{3} \mathrm{CN}\right)$ of a) $\left(\mathrm{Cl}^{-}\right)_{2} \subset 3^{6+}$, b) $\mathrm{Br}^{-} \subset 3^{6+}$ after adding 1 equiv. of $\mathrm{TBA}^{+} \cdot \mathrm{Cl}^{-}$, and c) $\left(\mathrm{Br}^{-}\right)_{2} \subset 3^{6+}$. The key resonances of the protons that are involved in hydrogen bonding interactions, including $\mathrm{NH}, \mathrm{H}_{\mathrm{f}}, \mathrm{H}_{\mathrm{g}}$ and $\mathrm{H}_{\mathrm{l}}$ are labeled. 
Upon addition one equiv. of $\mathrm{TBA}^{+\cdot} \cdot \mathrm{Cl}^{-}$into $\mathrm{Br}^{-} \subset 3^{6+} \cdot 5 \mathrm{PF}_{6}^{-}$(or addition of $\mathrm{TBA}^{+} \cdot \mathrm{Br}^{-}$into $\mathrm{Cl}^{-} \subset 3^{6+} \cdot 5 \mathrm{PF}_{6}{ }^{-}$), the resonances of the protons $\mathrm{H}_{\mathrm{g}}$ and $\mathrm{H}_{\mathrm{f}}$ were observed at 8.7 and 9.2 ppm, respectively. These two resonances are shifted compared to those in both $\left(\mathrm{Cl}^{-}\right)_{2} \subset 3^{6+}$ and $(\mathrm{Br}-)_{2} \subset 3^{6+}$, i.e., they shift upfield by 0.9 and $1.0 \mathrm{ppm}$ relative to $\left(\mathrm{Cl}^{-}\right)_{2} \subset \mathbf{3}^{6+}$, but are shifted downfield by 0.4 and $0.5 \mathrm{ppm}$ compared to those in $(\mathrm{Br})_{2} \subset 3^{6+}$. Assuming that 1) the chemical shifts of proton $\mathrm{H}_{\mathrm{f}}$ are influenced or mainly determined by the anions residing on the secondary binding station, 2) that $\mathrm{H}_{\mathrm{f}}$ in $\left(\mathrm{Cl}^{-} \cdot \mathrm{Br}^{-}\right) \subset 3^{6+}$ and $\left(\mathrm{Br}^{-} \cdot \mathrm{Cl}^{-}\right) \subset 3^{6+}$ have similar resonances as $\left(\mathrm{Br}^{-}\right)_{2} \subset 3^{6+}$ and $\left(\mathrm{Cl}^{-}\right)_{2} \subset 3^{6+}$, respectively, and that 3) the percentage of $\left(\mathrm{Cl}^{-} \cdot \mathrm{Br}\right) \subset 3^{6+}$ among the four possible complexes containing two anionic guests is $x$, and the percentage of $\left(\mathrm{Br}^{-} \cdot \mathrm{Cl}^{-}\right) \subset 3^{6+}$ is $y$, the percentage of $\left(\mathrm{Br}^{-}\right)_{2} \subset 3^{6+}$ and $\left(\mathrm{Cl}^{-}\right)_{2} \subset 3^{6+}$ should be both $(1-x-y) / 2$. Therefore, the following equation was deduced:

$\left(x+\frac{1-x-y}{2}\right) \times 8.7+\left(y+\frac{1-x-y}{2}\right) \times 10.2=9.2$.

In this equation, 9.2 is the signal corresponding to the observed resonance of $\mathrm{NH}$ protons upon addition $\mathrm{TBA}^{+} \cdot \mathrm{Br}^{-}$into $\mathrm{Cl}^{-} \subset 3^{6+} \cdot 5 \mathrm{PF}_{6}^{-}, 8.7$ is the signal corresponding to the resonance of $\mathrm{NH}$ protons of $\left(\mathrm{Br}^{-}\right)_{2} \subset 3^{6+}$ and $\left(\mathrm{Cl}^{-} \cdot \mathrm{Br}^{-}\right) \subset \mathbf{3}^{6+}$, and 10.2 is the signal corresponding to the resonance of the $\mathrm{NH}$ protons of $\left(\mathrm{Cl}^{-}\right)_{2} \subset 3^{6+}$ and $\left(\mathrm{Br}^{-} \cdot \mathrm{Cl}^{-}\right) \subset \mathbf{3}^{6+}$.

Using the above equation, we obtain:

$\left(\mathrm{Cl}^{-\cdot} \cdot \mathrm{Br}^{-}\right) \subset \mathbf{3}^{6+}: 1 / 3+\mathrm{m}$

$\left(\mathrm{Br}^{-} \cdot \mathrm{Cl}^{-}\right) \subset \mathbf{3}^{6+}: \mathrm{m}$

$\left(\mathrm{Br}^{-}\right)_{2} \subset \mathbf{3}^{6+}: 1 / 3-\mathrm{m}$

$\left(\mathrm{Cl}^{-}\right)_{2} \subset 3^{6+}: 1 / 3-\mathrm{m}$

where $\mathrm{m}$ is a number between 0 and $1 / 3$. 


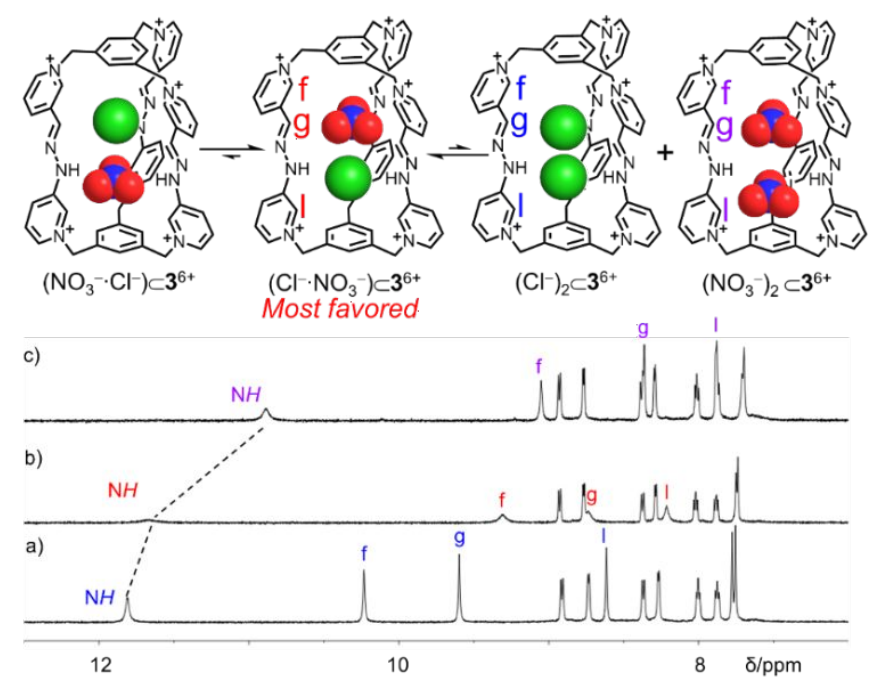

Figure 51. Partial ${ }^{1} \mathrm{H}$ NMR spectra $\left(298 \mathrm{~K}, \mathrm{CD}_{3} \mathrm{CN}\right)$ of a) $\left(\mathrm{Cl}^{-}\right)_{2} \subset 3^{6+}$, b) $\mathrm{Cl}^{-} \subset 3^{6+}$ after adding 1 equiv. of $\mathrm{TBA}^{+} \cdot \mathrm{NO}_{3}{ }^{-}$, and $\left.\mathrm{c}\right)\left(\mathrm{NO}_{3}{ }^{-}\right)_{2} \subset 3^{6+}$. The key resonances of protons that are involved in hydrogen bonding interactions, including $\mathrm{NH}, \mathrm{H}_{\mathrm{f}}, \mathrm{H}_{\mathrm{g}}$ and $\mathrm{H}_{\mathrm{l}}$ are labeled. The $\mathrm{NH}$ protons in b) have a similar shifts as in a), while $\mathrm{H}_{\mathrm{f}}$ and $\mathrm{H}_{\mathrm{g}}$ are close to those in $\mathrm{c}$ ), leading us to conclude that the sample in b) corresponds to $\left(\mathrm{Cl}^{-} \cdot \mathrm{NO}_{3}{ }^{-}\right) \subset 3^{6+}$.

By using a treatment analogous to that described above, the following equation was derived:

$$
\left(x+\frac{1-x-y}{2}\right) \times 9.1+\left(y+\frac{1-x-y}{2}\right) \times 10.2=9.3 .
$$

In this equation, 9.3 is the signal corresponding to the observed resonance of the $\mathrm{NH}$ protons seen upon the addition $\mathrm{TBA}^{+} . \mathrm{NO}_{3}{ }^{-}$into $\mathrm{Cl}^{-} \subset 3^{6+} \cdot 5 \mathrm{PF}_{6}{ }^{-}, 9.1$ is the signal corresponding to the resonance of $\mathrm{NH}$ protons of $\left(\mathrm{NO}_{3}{ }^{-}\right)_{2} \subset 3^{6+}$ and $\left(\mathrm{Cl}^{-\cdot} \mathrm{NO}_{3}{ }^{-}\right) \subset 3^{6+}$, and 10.2 is the signal corresponding to the resonance of $\mathrm{NH}$ protons of $\left(\mathrm{Cl}^{-}\right)_{2} \subset 3^{6+}$ and $\left(\mathrm{NO}_{3}^{-} \cdot \mathrm{Cl}^{-}\right) \subset 3^{6+}$.

By using this equation, we obtain:

$\left(\mathrm{Cl}^{-} \cdot \mathrm{NO}_{3}^{-}\right) \subset 3^{6+}: 0.64+\mathrm{m}$

$\left(\mathrm{NO}_{3}{ }^{-} \cdot \mathrm{Cl}^{-}\right) \subset 3^{6+}: \mathrm{m}$

$\left(\mathrm{NO}_{3}{ }^{-}\right)_{2} \subset 3^{6+}: 0.18-\mathrm{m}$

$\left(\mathrm{Cl}^{-}\right)_{2} \subset \mathbf{3}^{6+}: 0.18-\mathrm{m}$

where $\mathrm{m}$ is a number between 0 and 0.18 . 

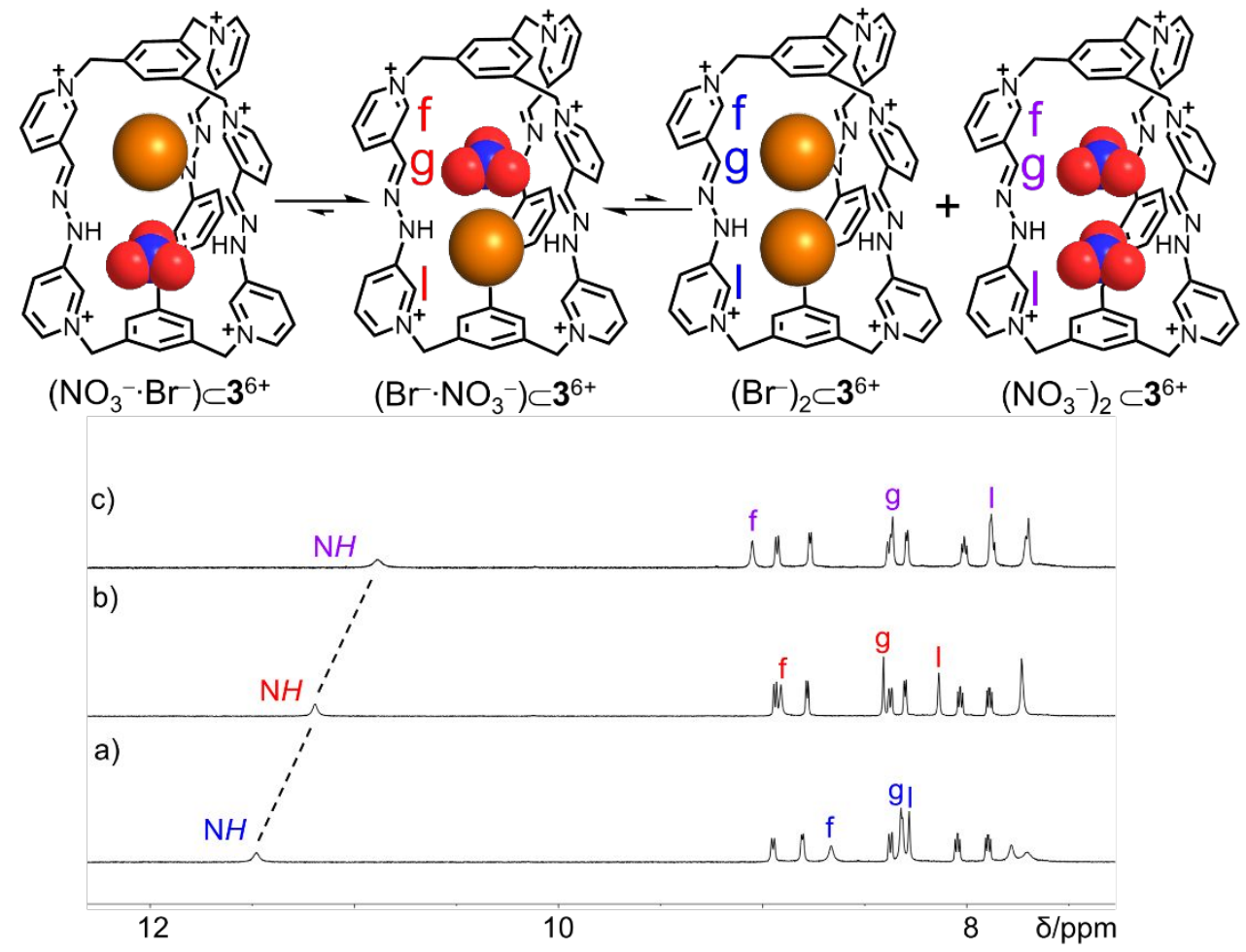

Figure 52. Partial ${ }^{1} \mathrm{H}$ NMR spectra $\left(298 \mathrm{~K}, \mathrm{CD}_{3} \mathrm{CN}\right)$ of a) $\left(\mathrm{Br}^{-}\right)_{2} \subset 3^{6+}$, b) $\mathrm{Br}^{-} \subset 3^{6+}$ after adding 1 equiv. of $\mathrm{TBA}^{+} \cdot \mathrm{NO}_{3}{ }^{-}$, and c) $\left(\mathrm{NO}_{3}{ }^{-}\right)_{2} \subset 3^{6+}$. The key resonances of protons that are involved in hydrogen bonding interactions, including $\mathrm{NH}, \mathrm{H}_{\mathrm{f}}, \mathrm{H}_{\mathrm{g}}$ and $\mathrm{H}_{\mathrm{l}}$ are labeled.

By using a similar method, we can calculate the content of each species, including $\left(\mathrm{Br} \cdot \mathrm{NO}_{3}^{-}\right) \subset 3^{6+},\left(\mathrm{NO}_{3}{ }^{-} \cdot \mathrm{Br}-\right) \subset 3^{6+},\left(\mathrm{NO}_{3}^{-}\right)_{2} \subset 3^{6+}$ and $(\mathrm{Br})_{2} \subset 3^{6+}$, respectively.

This yields the following results:

$\left(\mathrm{NO}_{3}^{-\cdot} \cdot \mathrm{Br}^{-}\right) \subset \mathbf{3}^{6+}: \mathrm{m}$

$\left(\mathrm{Br}^{-} \cdot \mathrm{NO}_{3}{ }^{-}\right) \subset 3^{6+}: \mathrm{m}$

$\left(\mathrm{Br}^{-}\right)_{2} \subset 3^{6+}: 0.5-\mathrm{m}$

$\left(\mathrm{NO}_{3}{ }^{-}\right)_{2} \subset 3^{6+}: 0.5-\mathrm{m}$

where $\mathrm{m}$ is a number between 0 and 0.5 . 


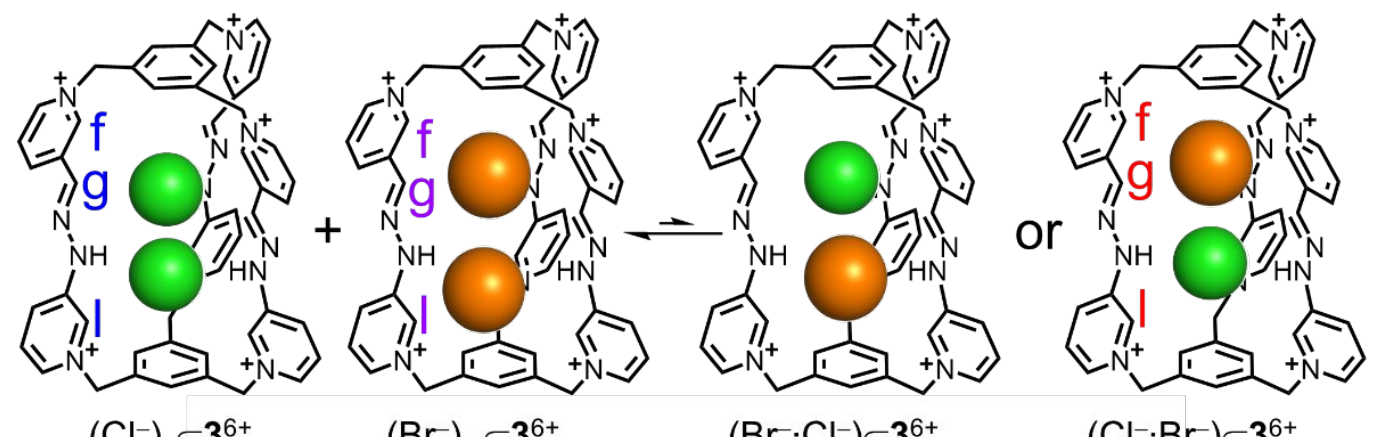
$\left(\mathrm{Cl}^{-}\right)_{2} \subset 3^{6+}$
$(\mathrm{Br})_{2} \subset 3^{6+}$
$\left(\mathrm{Br} \cdot \mathrm{Cl}^{-}\right) \subset 3^{6+}$
$\left(\mathrm{Cl}^{-} \cdot \mathrm{Br}^{-}\right) \subset 3^{6+}$

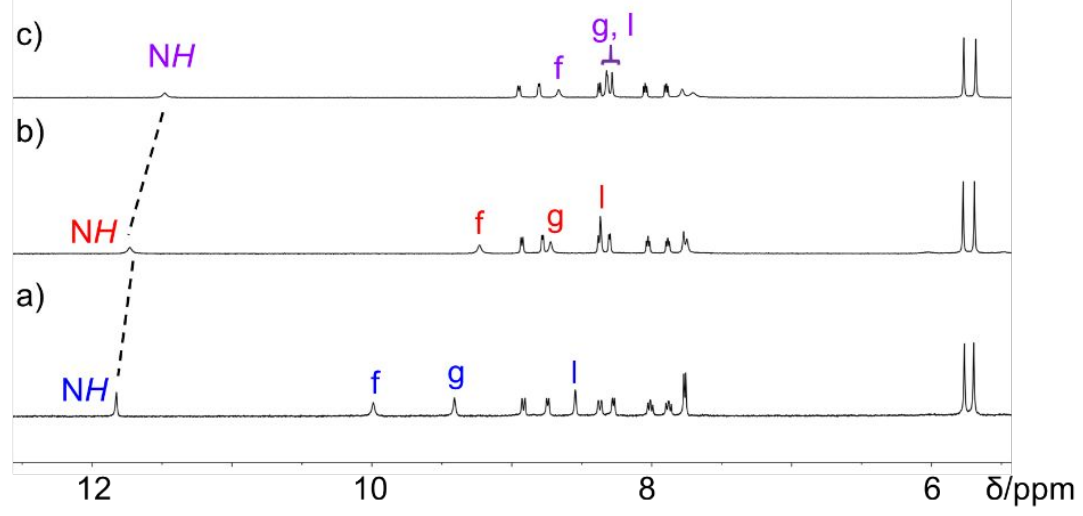

Figure 53. Partial ${ }^{1} \mathrm{H}$ NMR spectra $\left(298 \mathrm{~K}, \mathrm{CD}_{3} \mathrm{CN}\right)$ of a) $\left(\mathrm{Cl}^{-}\right)_{2} \subset 3^{6+}$, b) the mixture of $\left(\mathrm{Cl}^{-}\right)_{2} \subset 3^{6+}$ and $(\mathrm{Br})_{2} \subset \mathbf{3}^{6+}$ in 1:1 ratio, and c) $\left(\mathrm{Br}^{-}\right)_{2} \subset \mathbf{3}^{6+}$.

The ${ }^{1} \mathrm{H}$ NMR spectrum of a $1: 1$ mixture of $\left(\mathrm{Cl}^{-}\right)_{2} \subset 3^{6+}$ and $(\mathrm{Br})_{2} \subset 3^{6+}$ is almost identical to spectrum seen upon the addition of one equiv. of $\mathrm{TBA}^{+} \cdot \mathrm{Cl}^{-}$into a $\mathrm{CD}_{3} \mathrm{CN}$ solution of $\mathrm{Br}^{-} \subset 3^{6+} \cdot 5 \mathrm{PF}_{6}{ }^{-}$. This observation is consistent with the two anionic guests undergoing fast host-guest exchange with one another and the cage. 

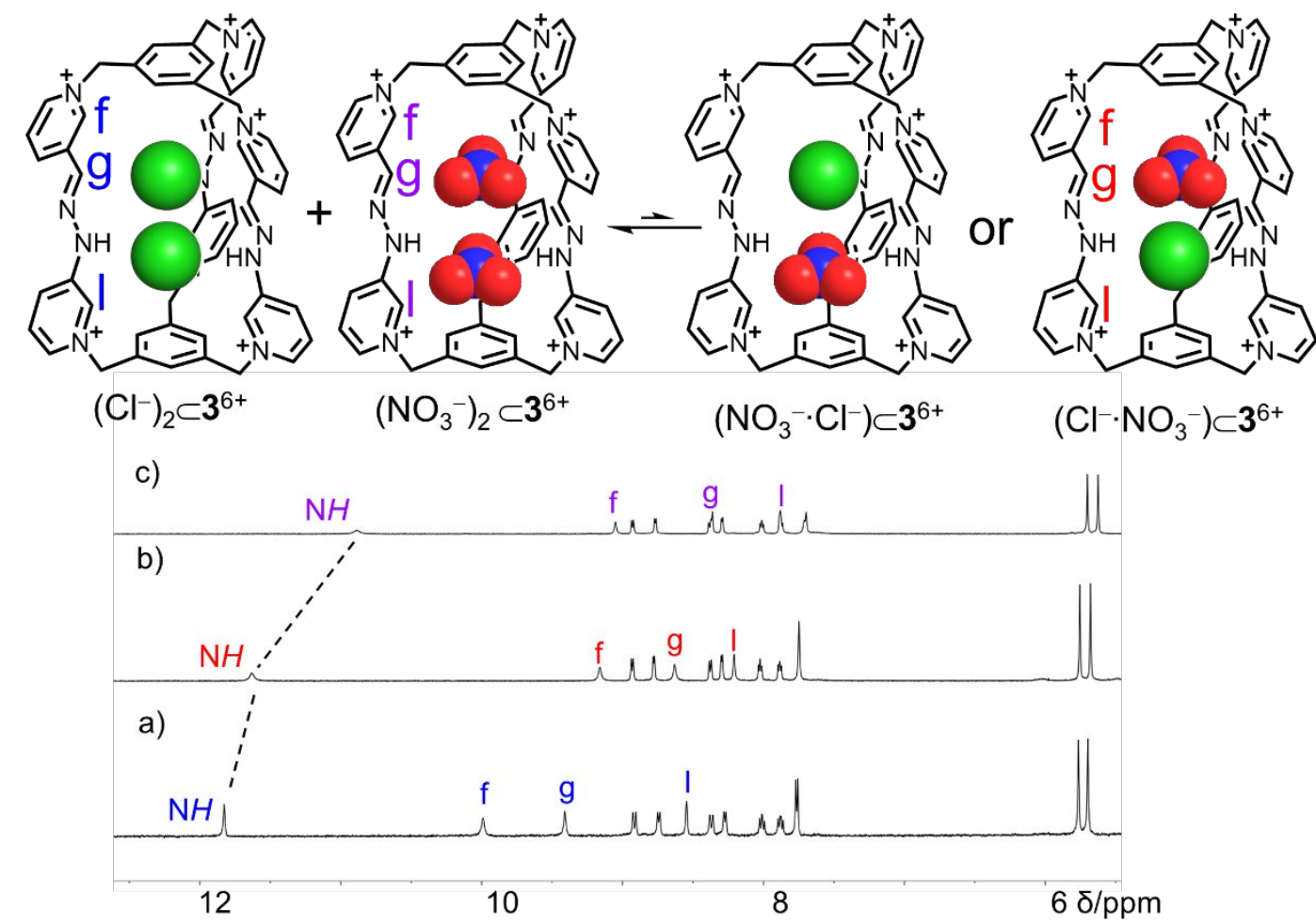

Figure 54. Partial ${ }^{1} \mathrm{H}$ NMR spectra $\left(298 \mathrm{~K}, \mathrm{CD}_{3} \mathrm{CN}\right)$ of a) $\left(\mathrm{Cl}^{-}\right)_{2} \subset 3^{6+}$, b) the mixture of $\left(\mathrm{Cl}^{-}\right)_{2} \subset 3^{6+}$ and $\left(\mathrm{NO}_{3}{ }^{-}\right)_{2} \subset 3^{6+}$ in 1:1 ratio, and c) $\left(\mathrm{NO}_{3}{ }^{-}\right)_{2} \subset 3^{6+}$.

The ${ }^{1} \mathrm{H}$ NMR spectrum of a $1: 1$ mixture of $\left(\mathrm{Cl}^{-}\right)_{2} \subset 3^{6+}$ and $\left(\mathrm{NO}_{3}{ }^{-}\right)_{2} \subset 3^{6+}$ is almost identical to spectrum seen upon the addition one equiv. of $\mathrm{TBA}^{+} \cdot \mathrm{Cl}^{-}$into a $\mathrm{CD}_{3} \mathrm{CN} \mathrm{NO}_{3}{ }^{-} \subset 3^{6+} \cdot 5 \mathrm{PF}_{6}{ }^{-}$. This observation is consistent with the two anionic guests undergoing fast host-guest exchange with one another and the cage. 


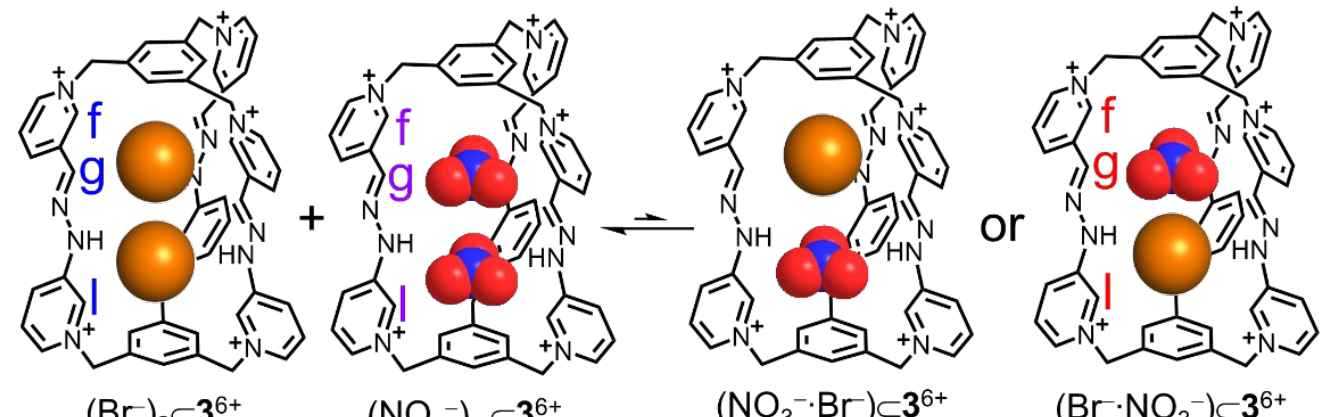
$(\mathrm{Br})_{2} \subset 3^{6+}$
$\left(\mathrm{NO}_{3}{ }^{-}\right)_{2} \subset 3^{6+}$
$\left(\mathrm{NO}_{3}^{-} \cdot \mathrm{Br}\right) \subset 3^{6+}$
$\left(\mathrm{Br} \cdot \mathrm{NO}_{3}^{-}\right) \subset 3^{6+}$

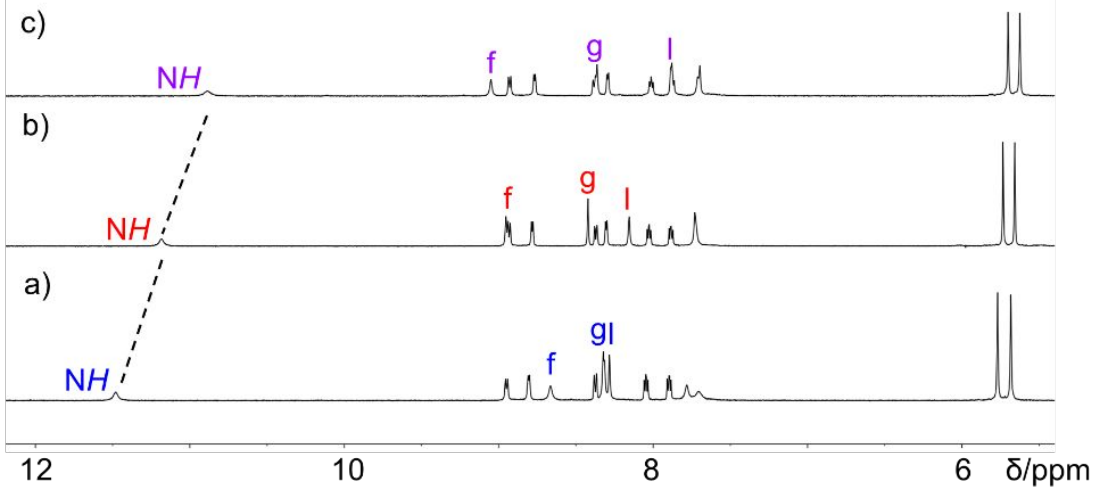

Figure 55. Partial ${ }^{1} \mathrm{H}$ NMR spectra $\left(298 \mathrm{~K}, \mathrm{CD}_{3} \mathrm{CN}\right)$ of a) $(\mathrm{Br})_{2} \subset 3^{6+}$, b) the mixture of $(\mathrm{Br}-)_{2} \subset 3^{6+}$ and $\left(\mathrm{NO}_{3}{ }^{-}\right)_{2} \subset 3^{6+}$ in 1:1 ratio, and c) $\left(\mathrm{NO}_{3}{ }^{-}\right)_{2} \subset 3^{6+}$.

The ${ }^{1} \mathrm{H}$ NMR spectrum of a 1:1 mixture of $\left(\mathrm{NO}_{3}{ }^{-}\right)_{2} \subset 3^{6+}$ and $(\mathrm{Br})_{2} \subset 3^{6+}$ is almost identical to the spectrum obtained upon the addition one equiv. of $\mathrm{TBA}^{+} \cdot \mathrm{NO}_{3}{ }^{-}$into a $\mathrm{CD}_{3} \mathrm{CN}$ solution of $\mathrm{Br} \subset 3^{6+} \cdot 5 \mathrm{PF}_{6}{ }^{-}$. This observation is consistent with the two anionic guests undergoing fast host-guest exchange with one another and the cage. 


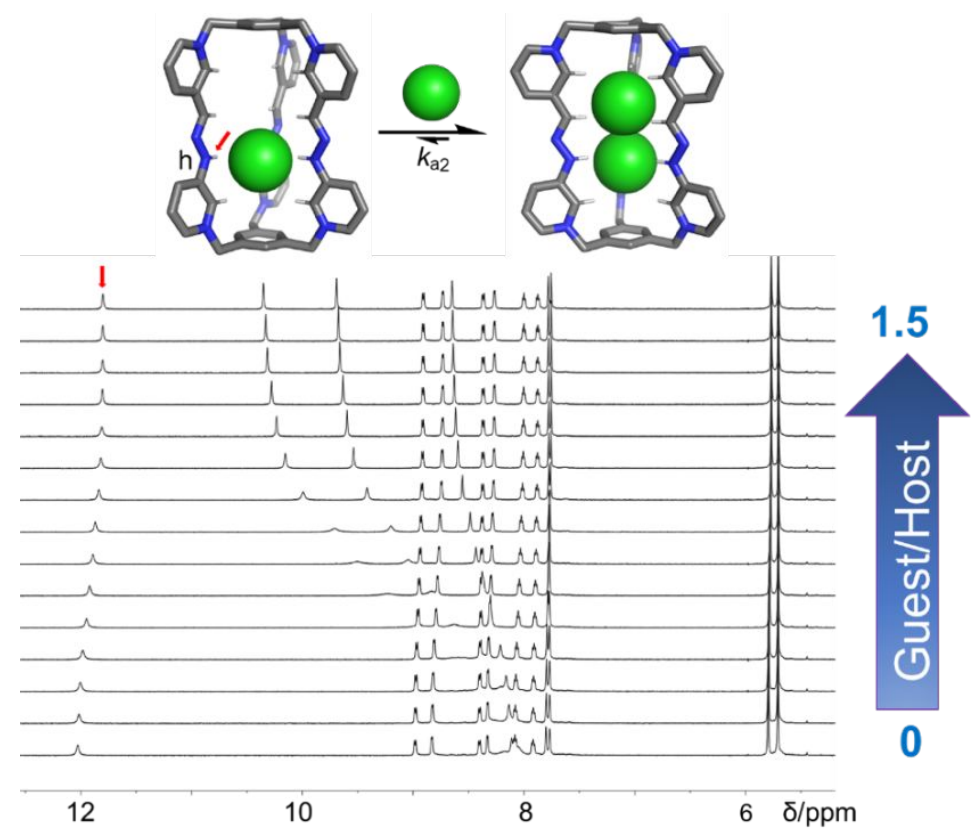

Figure S56. Partial ${ }^{1} \mathrm{H}$ NMR spectra $\left(600 \mathrm{MHz}, \mathrm{CD}_{3} \mathrm{CN}, 298 \mathrm{~K}\right)$ of $\mathrm{Cl}^{-} \subset 3^{6+} .5 \mathrm{PF}_{6}{ }^{-}$upon addition of 0-1.5 equiv. $\mathrm{TBA}^{+} \cdot \mathrm{Cl}^{-} \cdot\left[\mathrm{Cl}^{-} \subset 3^{6+} \cdot 5 \mathrm{PF}_{6}{ }^{-}\right]=1 \mathrm{mM}$ for all spectra. The key resonances, proton $\mathrm{h}$ in $3^{6+}$, is labeled with a red arrow in the spectra. We used the extent of the upfield shift, $\Delta \delta$, as a function of concentration to calculate the binding constant.

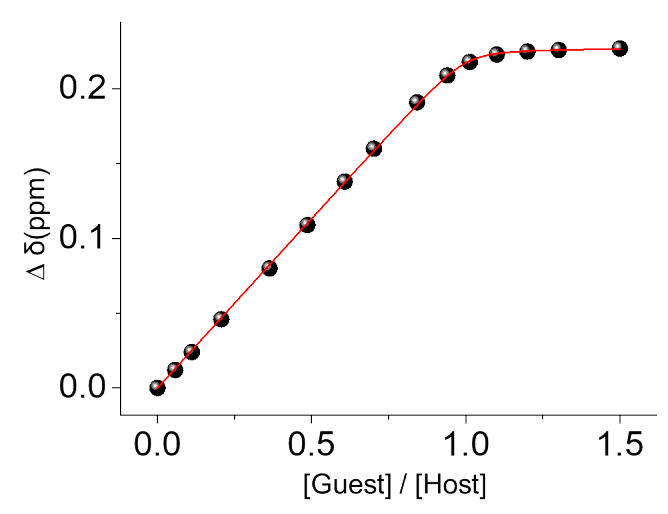

Figure S57. Plot of the resonance upfield shifts of proton $\mathrm{h}$ of $3^{6+}$ versus $\left[\mathrm{Cl}^{-}\right] /\left[3^{6+}\right]$. See the assignment of proton $\mathrm{h}$ in Figure $\mathrm{S} 56 .\left[\mathrm{Cl}^{-} \subset 3^{6+} \cdot 5 \mathrm{PF}_{6}^{-}\right]=1 \mathrm{mM}$ for all spectra.

Proton NMR spectroscopic titrations were performed (Figure S56) in an effort to determine the binding constant $K_{\mathrm{a} 2}$ corresponding to the formation of $\left(\mathrm{Cl}^{-}\right)_{2} \subset 3^{6+}$. Towards this end a sample of $\mathrm{Cl}^{-} \subset 3^{6+} \cdot 5 \mathrm{PF}_{6}^{-}$was titrated with $\mathrm{TBA}^{+} \cdot \mathrm{Cl}^{-}$in $\mathrm{CD}_{3} \mathrm{CN}$. The corresponding ${ }^{1} \mathrm{H}$ NMR spectra demonstrated (Figure S57) allowed a $K_{\mathrm{a} 2}$ of $4.7( \pm 1.3) \times$ $10^{5} \mathrm{M}^{-1}$ to be derived. 


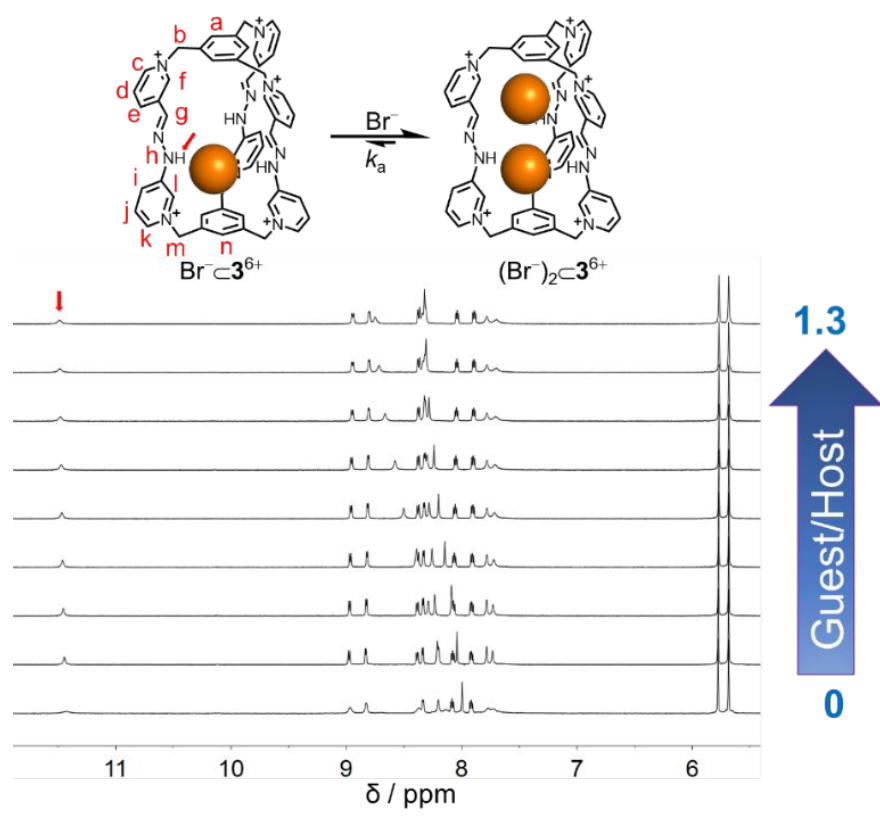

Figure S58. Partial ${ }^{1} \mathrm{H}$ NMR spectra $\left(600 \mathrm{MHz}, \mathrm{CD}_{3} \mathrm{CN}, 298 \mathrm{~K}\right)$ of $\mathrm{Br}^{-} \subset 3^{6+} \cdot 5 \mathrm{PF}_{6}{ }^{-}$upon addition of 0-1.3 equiv. $\mathrm{TBA}^{+} \cdot \mathrm{Br} \cdot\left[\mathrm{Br}^{-} \subset 3^{6+} \cdot 5 \mathrm{PF}_{6}{ }^{-}\right]=1 \mathrm{mM}$ for all spectra. The key resonances, proton $\mathrm{h}$ in $3^{6+}$, is labeled with a red arrow in the spectra. We used the extent of the downfield shift, $\Delta \delta$, as a function of concentration to calculate the binding constant.

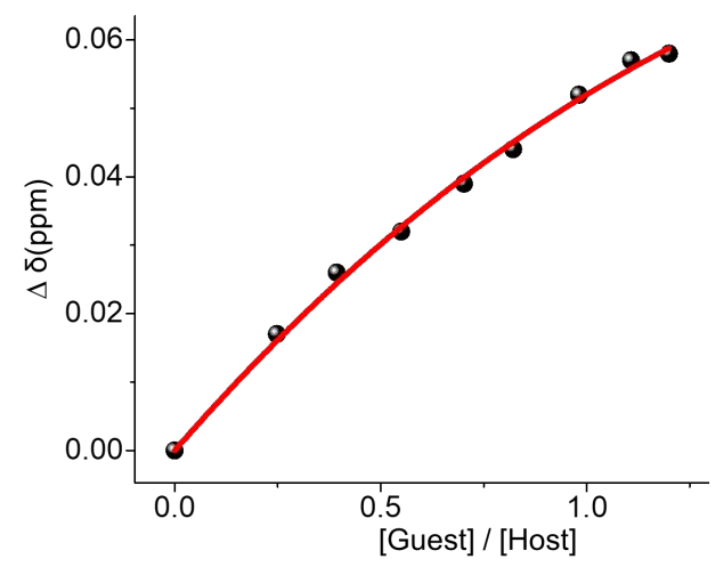

Figure S59 Plot of the downfield shift of the signal corresponding to proton $\mathrm{h}$ of $\mathbf{3}^{6+}$ versus $[\mathrm{Br}-] /\left[3^{6+}\right]$. See the assignment of proton $\mathrm{h}$ in Figure $\mathrm{S} 58 .\left[\mathrm{Br}^{-} \subset 3^{6+} \cdot 5 \mathrm{PF}_{6}^{-}\right]=1 \mathrm{mM}$ for all spectra.

${ }^{1} \mathrm{H}$ NMR spectroscopic studies were performed (Figure S58) to calculate the binding constant $K_{\mathrm{a} 2}$ corresponding to the formation of $\left(\mathrm{Br}^{-}\right)_{2} \subset 3^{6+}$. We titrated the sample of $\mathrm{Br}^{-} \subset 3^{6+} \cdot 5 \mathrm{PF}_{6}{ }^{-}$with $\mathrm{TBA}^{+} \cdot \mathrm{Br}^{-}$in $\mathrm{CD}_{3} \mathrm{CN}$. From the corresponding ${ }^{1} \mathrm{H}$ NMR spectra (Figure S59) a $K_{\mathrm{a} 2}$ value of around $1.3( \pm 0.7) \times 10^{3} \mathrm{M}^{-1}$ was calculated. 


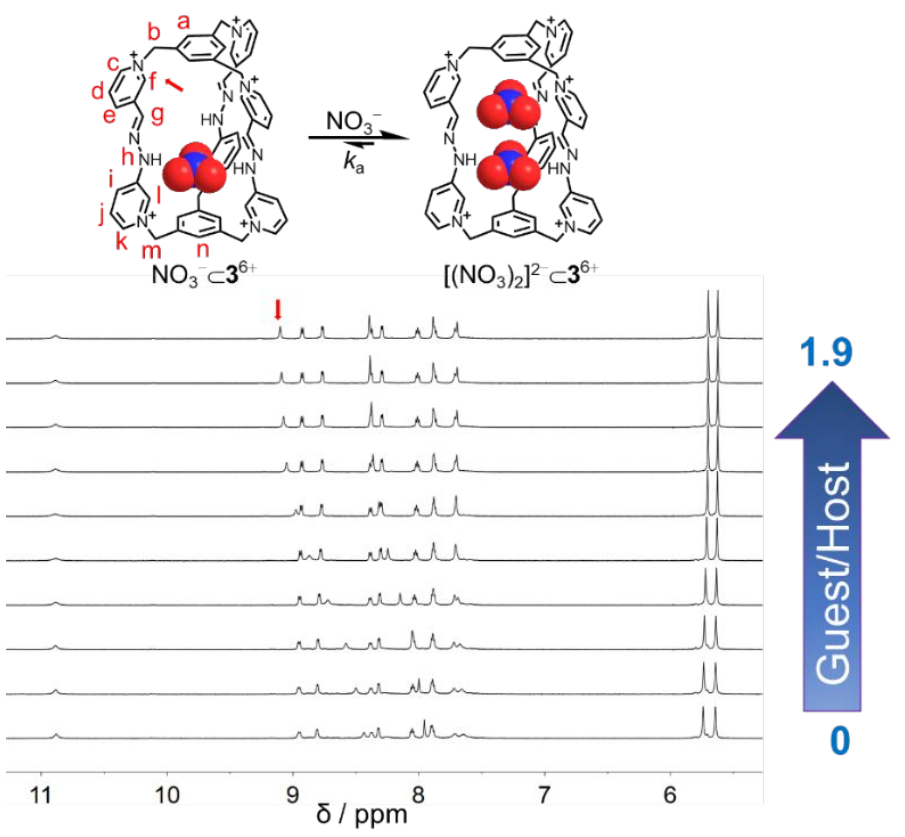

Figure S60. Partial ${ }^{1} \mathrm{H}$ NMR spectra $\left(600 \mathrm{MHz}, \mathrm{CD}_{3} \mathrm{CN}, 298 \mathrm{~K}\right)$ of $\mathrm{NO}_{3}{ }^{-} \subset 3^{6+} \cdot 5 \mathrm{PF}_{6}{ }^{-}$upon addition of 0-1.9 equiv. $\mathrm{TBA}^{+} \cdot \mathrm{NO}_{3}{ }^{-} \cdot\left[\mathrm{NO}_{3}{ }^{-} \subset 3^{6+} \cdot 5 \mathrm{PF}_{6}{ }^{-}\right]=1 \mathrm{mM}$ for all spectra. The key resonances, proton $\mathrm{f}$ in $3^{6+}$, is labeled with a red arrow in the spectra. We used the extent of the downfield shift, $\Delta \delta$, as a function of concentration to calculate the binding constant.

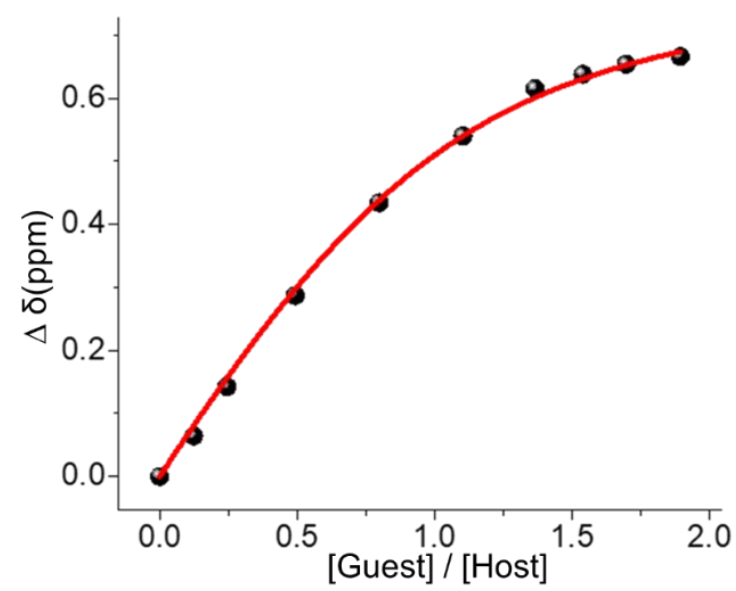

Figure S61. Plot of the resonance downfield shifts of proton $h$ of $3^{6+}$ verus $\left[\mathrm{NO}_{3}-\right] /\left[3^{6+}\right]$. See the assignment of proton $\mathrm{h}$ in Figure 60. $\left[\mathrm{NO}_{3}{ }^{-} \subset 3^{6+} \cdot 5 \mathrm{PF}_{6}{ }^{-}\right]=1 \mathrm{mM}$ for all spectra.

${ }^{1} \mathrm{H}$ NMR spectroscopic titrations were carried (Figure S60) in an effort to calculate the binding constant $K_{\mathrm{a} 2}$ corresponding to the formation of $\left(\mathrm{NO}_{3}{ }^{-}\right)_{2} \subset 3^{6+}$. Toward this end, a sample of $\mathrm{NO}_{3}{ }^{-} \subset 3^{6+} \cdot 5 \mathrm{PF}_{6}{ }^{-}$was titrated with $\mathrm{TBA}^{+} \cdot \mathrm{NO}_{3}{ }^{-}$in $\mathrm{CD}_{3} \mathrm{CN}$. The corresponding ${ }^{1} \mathrm{H}$ NMR spectra (Figure S61) allowed a $K_{\mathrm{a} 2}$ of around $4.4( \pm 1.1) \times 10^{3} \mathrm{M}^{-1}$ to be calculated. 


\section{X-ray crystallography}

1) $3^{6+} \cdot 6 \mathrm{Cl}^{-}$

a) Methods

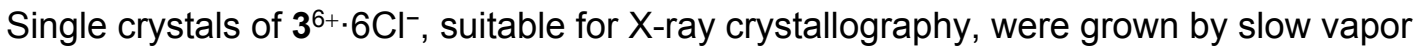
diffusion of acetone into a solution of $3^{6+} \cdot 6 \mathrm{Cl}^{-}$(in water) over the course of days. Data were collected at $173 \mathrm{~K}$ on a Bruker D8 Venture Diffractometer equipped with a GaKa I $\mu S$ source and MX optic.

b) Crystal parameters

$\left[\mathrm{C}_{51} \mathrm{H}_{58} \mathrm{Cl}_{6} \mathrm{~N}_{12} \mathrm{O}_{5}\right]$, Red block $(0.08 \times 0.06 \times 0.05 \mathrm{~mm})$, monoclinic, space group $\mathrm{C} 12 / \mathrm{c} 1$, $a=13.0476(9) \AA, b=18.8115(14) \AA, c=24.8223(18) \AA, \alpha=90^{\circ}, \beta=92.579(3)^{\circ}, \gamma=90^{\circ}$, $V=6086.3(8) \AA^{3}, Z=4, T=173 \mathrm{~K}, \rho_{\text {calc }}=1.235 \mathrm{~g} / \mathrm{cm}^{3}, \mu(\mathrm{GaK \alpha})=1.34139 \mathrm{~mm}^{-1}$. A total of 5713 reflections were collected, of which 5130 were unique. Final $R_{1}(I>2 \sigma(I))=0.1348$ and $w R_{2}=0.3022$ (all data). The structure was solved by direct method and different Fourier syntheses. Using Olex2, the structure was solved with the ShelXT structure solution program using Intrinsic Phasing and refined with the ShelXL refinement package using Least Squares minimization. CCDC number: 2014359.

c) Solid-state structure

a)

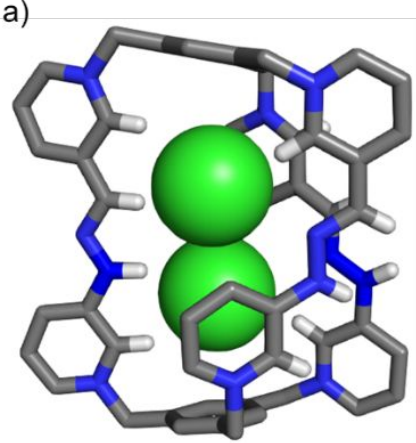

b)

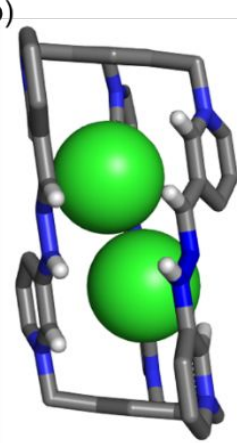

c)

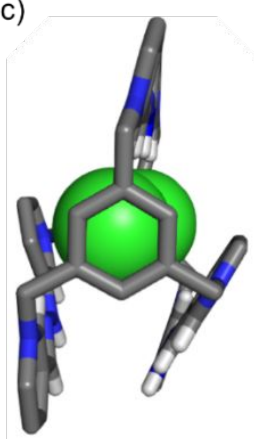

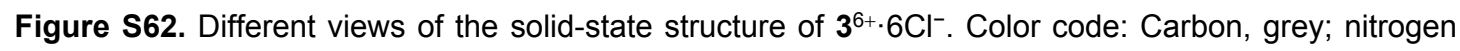
blue; hydrogen, white; chlorine, green. Disordered solvent molecules, other counterions, and hydrogen atoms which are not involved in hydrogen bonding interactions are omitted for clarity.

2) $\mathrm{Cl}^{-} \subset 3^{6+} \cdot 5 \mathrm{PF}_{6}^{-}$

a) Methods

Single crystals of $\mathrm{Cl}^{-} \subset 3^{6+} \cdot 5 \mathrm{PF}_{6}^{-}$, suitable for $\mathrm{X}$-ray crystallography, were grown by slow 
vapor diffusion of isopropyl ether into a solution of $\mathrm{Cl}^{-} \subset 3^{6+} \cdot 5 \mathrm{PF}_{6}{ }^{-}$in $\mathrm{CH}_{3} \mathrm{CN}$ over the course of days. Data were collected at $170 \mathrm{~K}$ on a Bruker D8 Venture Diffractometer equipped with a MoKa I $\mu S$ source and MX optic.

b) Crystal parameters

$\left[\mathrm{C}_{55} \mathrm{H}_{54} \mathrm{ClF}_{30} \mathrm{~N}_{14} \mathrm{P}_{5}\right]$, yellow block $(0.4 \times 0.29 \times 0.23 \mathrm{~mm})$, monoclinic, space group P1 $21 / \mathrm{n} \mathrm{1}, a=15.633(14) \AA, b=26.74(2) \AA, c=16.948(14) \AA, \alpha=90^{\circ}, \beta=103.15(4)^{\circ}, y=$ $90^{\circ}, V=6899(10) \AA^{3}, Z=4, T=170 \mathrm{~K}, \rho_{\text {calc }}=1.609 \mathrm{~g} / \mathrm{cm}^{3}, \mu(\mathrm{MoK \alpha})=0.71073 \mathrm{~mm}^{-1} . A$ total of 13891 reflections were collected, of which 8357 were unique. Final $R_{1}(I>2 \sigma(I))=$ 0.0899 and $w R_{2}=0.2783$ (all data). The structure was solved by direct method and different Fourier syntheses. Using Olex2, the structure was solved with the ShelXT structure solution program using Intrinsic Phasing and refined with the ShelXL refinement package using Least Squares minimization. CCDC number: 2014341.

c) Solid-state structure
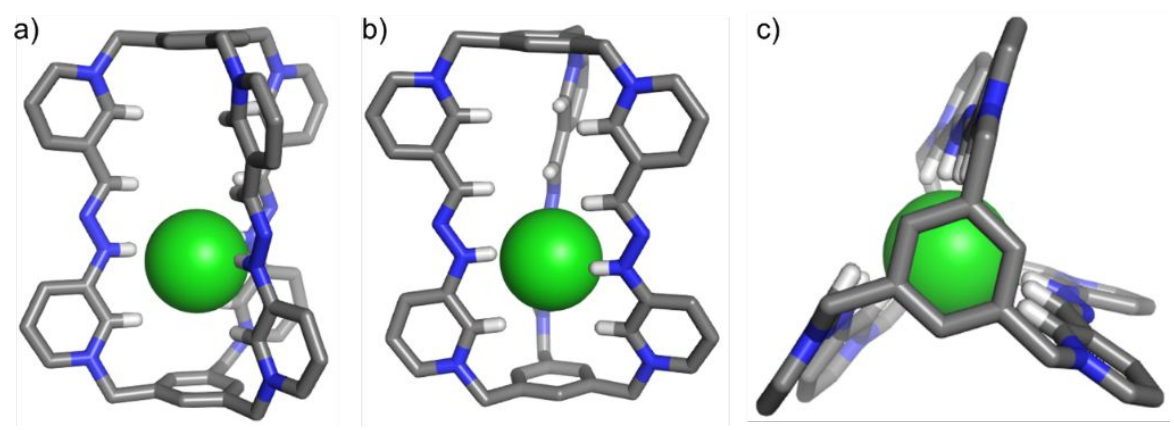

Figure S63. Different views of the solid-state structure of $\mathrm{Cl}^{-} \subset 3^{6+} \cdot 5 \mathrm{PF}_{6}{ }^{-}$. Color code: Carbon, grey; nitrogen, blue; hydrogen, white; chlorine, green. Disordered solvent molecules, other counterions, and hydrogen atoms which are not involved in hydrogen bonding interactions are omitted for the sake of clarity.

3) $\left(\mathrm{Cl}^{-}\right)_{2} \subset \mathbf{3}^{6+} \cdot 4 \mathrm{PF}_{6}^{-}$

a) Methods

Single crystals of $\left(\mathrm{Cl}^{-}\right)_{2} \subset 3^{6+} \cdot 4 \mathrm{PF}_{6}{ }^{-}$, suitable for X-ray crystallography, were grown by slow vapor diffusion of isopropyl ether into mixed solutions of $\mathrm{Cl}^{-} \subset 3^{6+} \cdot 5 \mathrm{PF}_{6}{ }^{-}$and $\mathrm{NH}_{4}{ }^{+} \cdot \mathrm{Cl}^{-}$ (2 equiv.) in MeCN over the course of several days. Data were collected at $173 \mathrm{~K}$ on a Bruker D8 Venture Diffractometer equipped with a GaKa I $\mu$ S source and MX optic.

b) Crystal parameters 
$\left[\mathrm{C}_{55} \mathrm{H}_{54} \mathrm{Cl}_{2} \mathrm{~F}_{24} \mathrm{~N}_{14} \mathrm{OP}_{4}\right]$, yellow block $(0.08 \times 0.08 \times 0.05 \mathrm{~mm})$, monoclinic, space group $\mathrm{P} 121 / \mathrm{n} 1, a=15.4799(8) \AA, b=26.6956(14) \AA, c=16.948(14) \AA, \alpha=90^{\circ}, \beta=98.955(3)^{\circ}$, $y=90^{\circ}, V=6830.3(6) \AA^{3}, Z=4, T=173 \mathrm{~K}, \rho_{\text {calc }}=1.534 \mathrm{~g} / \mathrm{cm}^{3}, \mu(\mathrm{GaK \alpha})=1.34139 \mathrm{~mm}^{-1}$. A total of 12910 reflections were collected, of which 9216 were unique. Final $R_{1}(I>2 \sigma(I))$ $=0.1333$ and $w R_{2}=0.3085$ (all data). The structure was solved by direct method and different Fourier syntheses. Using Olex2, the structure was solved with the ShelXT structure solution program using Intrinsic Phasing and refined with the ShelXL refinement package using Least Squares minimization. CCDC number: 2014360.

c) Solid-state structure
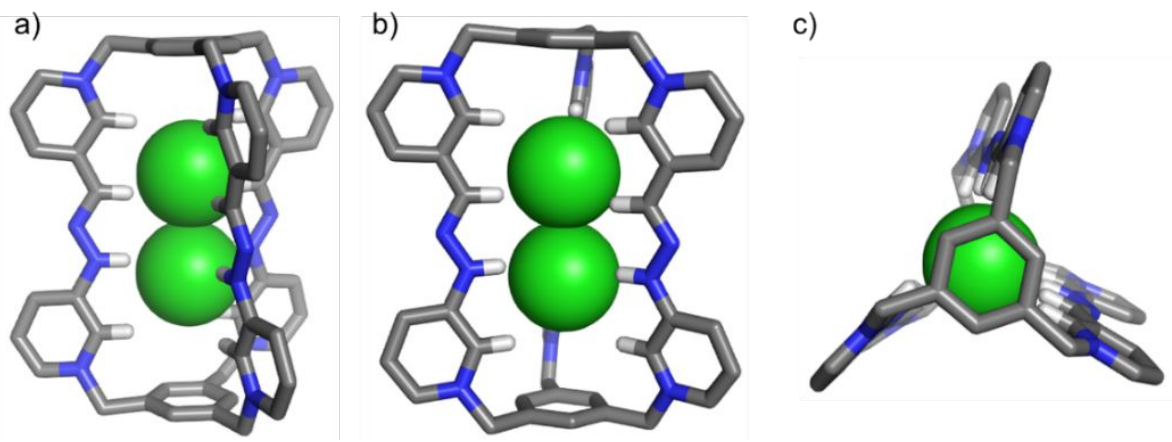

Figure S64. Different views of the solid-state structure of $\left(\mathrm{Cl}^{-}\right)_{2} \subset 3^{6+} \cdot 4 \mathrm{PF}_{6}{ }^{-}$. Color coder: Carbon, grey; nitrogen, blue; hydrogen, white; chlorine, green. Disordered solvent molecules, other counterions, and hydrogen atoms which are not involved in hydrogen bonding interactions are omitted for the sake of clarity.

4) $\left(\mathrm{Cl}^{-} \cdot \mathrm{Br}^{-}\right) \subset 3^{6+} \cdot 4 \mathrm{PF}_{6}^{-}$

a) Methods

Single crystals of $\left(\mathrm{Cl}^{-} \cdot \mathrm{Br}^{-}\right) \subset 3^{6+} \cdot 4 \mathrm{PF}_{6}^{-}$, suitable for X-ray crystallography, were grown by slow vapor diffusion of isopropyl ether into mixed solutions of $\mathrm{Cl}^{-} \subset 3^{6+} \cdot 5 \mathrm{PF}_{6}{ }^{-}$and $\mathrm{NH}_{4}{ }^{+\cdot} \mathrm{Br}$ (1.5 eq.) in MeCN over the course of days. Data were collected at $195 \mathrm{~K}$ on a Bruker D8 Venture Diffractometer equipped with a GaKa I $\mu$ S source and MX optic.

b) Crystal parameters

$\left[\mathrm{C}_{55} \mathrm{H}_{54} \mathrm{Br}_{1.25} \mathrm{Cl}_{0.75} \mathrm{~F}_{24} \mathrm{~N}_{14} \mathrm{P}_{4}\right]$, yellow block $(0.06 \times 0.06 \times 0.05 \mathrm{~mm})$, monoclinic, space group P1 21/n 1, $a=15.4898(9) \AA, b=26.5690(17) \AA, c=16.7207(10) \AA, \alpha=90^{\circ}, \beta=$ 99.122(4) $)^{\circ}, y=90^{\circ}, V=6794.4(7) \AA^{3}, Z=4, T=195 \mathrm{~K}, \rho_{\text {calc }}=1.581 \mathrm{~g} / \mathrm{cm}^{3}, \mu(\mathrm{GaK \alpha})=$ 
$1.34139 \mathrm{~mm}^{-1}$. A total of 12891 reflections were collected, of which 5708 were unique. Final $R_{1}(I>2 \sigma(I))=0.1464$ and $w R_{2}=0.3751$ (all data). The structure was solved by direct method and different Fourier syntheses. Using Olex2, the structure was solved with the ShelXT structure solution program using Intrinsic Phasing and refined with the ShelXL refinement package using Least Squares minimization. CCDC number: 2014362.

c) Solid-state structure
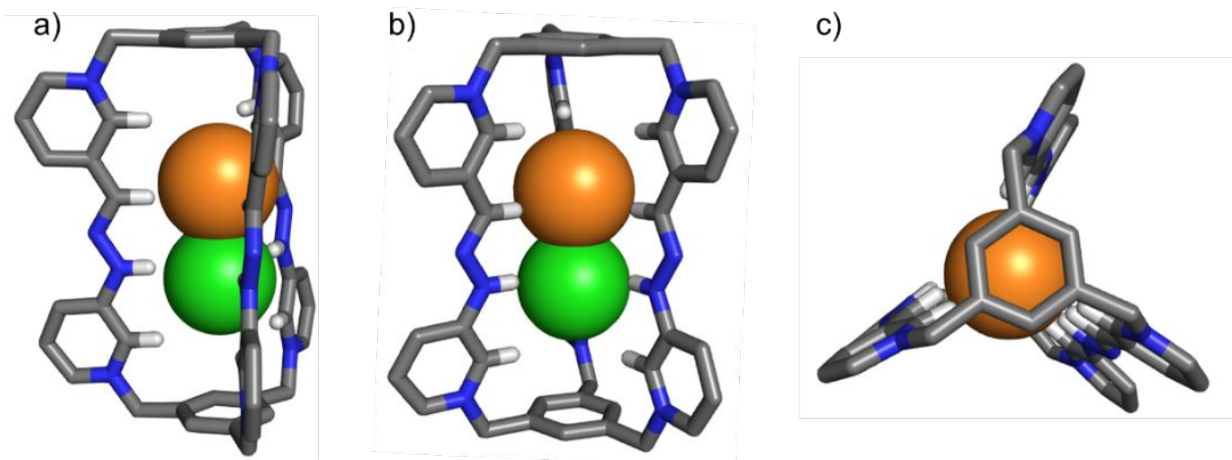

Figure S65. Different views of the solid-state structure of $\left(\mathrm{Cl}^{-} \cdot \mathrm{Br}^{-}\right) \subset 3^{6+} \cdot 4 \mathrm{PF}_{6}{ }^{-}$. Carbon, grey; nitrogen, blue; hydrogen, white; chlorine, green; bromine, orange. Disordered solvent molecules, other counterions, and hydrogen atoms which are not involved in hydrogen bonding interactions are omitted for clarity.

5) $\mathrm{Br}^{-} \subset 3^{6+} \cdot 5 \mathrm{PF}_{6}^{-}$

a) Methods

Single crystals of $\mathrm{Br}^{-} \subset 3^{6+} \cdot 5 \mathrm{PF}_{6}^{-}$, suitable for $\mathrm{X}$-ray crystallography, were grown by slow vapor diffusion of isopropyl ether into mixed solutions of $6^{6+\cdot} 6 \mathrm{PF}_{6}{ }^{-}$and $\mathrm{NH}_{4}{ }^{+\cdot} \mathrm{Br}$ (2 equiv.) in MeCN over the course of days. Data were collected at $195 \mathrm{~K}$ on a Bruker D8 Venture Diffractometer equipped with a GaKa I $\mu$ S source and MX optic.

b) Crystal parameters

$\left[\mathrm{C}_{54.50} \mathrm{H}_{53.25} \mathrm{BrF}_{30} \mathrm{~N}_{13.75} \mathrm{P}_{5}\right]$, yellow block $(0.1 \times 0.08 \times 0.08 \mathrm{~mm})$, monoclinic, space group P1 21/n 1, $a=15.5011(8) \AA, \quad b=26.6150(14) \AA, \quad c=16.9891(8) \AA, \quad \alpha=90^{\circ}, \quad \beta=$ 102.109(3) $)^{\circ}, y=90^{\circ}, V=6853.1(6) \AA^{3}, Z=4, T=195 \mathrm{~K}, \rho_{\text {calc }}=1.653 \mathrm{~g} / \mathrm{cm}^{3}, \mu(\mathrm{GaK \alpha})=$ $1.34139 \mathrm{~mm}^{-1}$. A total of 12981 reflections were collected, of which 7710 were unique. Final $R_{1}(I>2 \sigma(I))=0.1332$ and $w R_{2}=0.3402$ (all data). The structure was solved by direct method and different Fourier syntheses. Using Olex2, the structure was solved with 
the ShelXT structure solution program using Intrinsic Phasing and refined with the ShelXL refinement package using Least Squares minimization. CCDC number: 2014363.

c) Solid-state structure
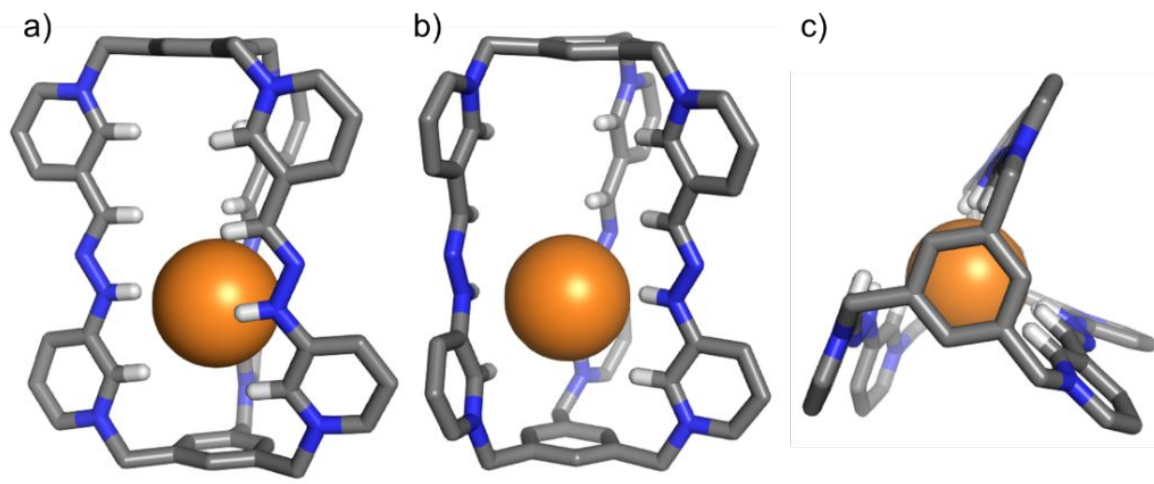

Figure S66. Different views of the solid-state structure of $\mathrm{Br}^{-} \subset 3^{6+} .5 \mathrm{PF}_{6}{ }^{-}$. Color codes: Carbon, grey; nitrogen, blue; hydrogen, white; bromine, orange. Disordered solvent molecules, other counterions, and hydrogen atoms which are not involved in hydrogen bonding interactions are omitted for clarity.

6) $\mathrm{NO}_{3}{ }^{-} \subset 3^{6+} \cdot 5 \mathrm{PF}_{6}-$

a) Methods

Single crystals of $\mathrm{NO}_{3}{ }^{-} \subset 3^{6+} \cdot 5 \mathrm{PF}_{6}{ }^{-}$, suitable for $\mathrm{X}$-ray crystallography, were grown by slow vapor diffusion of isopropyl ether into mixed solutions of $3^{6+} \cdot 6 \mathrm{PF}_{6}{ }^{-}$and $\mathrm{NH}_{4}{ }^{+} \cdot \mathrm{NO}_{3}{ }^{-}$ (1.5 equiv.) in MeCN over the course of days. Data were collected at $195 \mathrm{~K}$ on a Bruker D8 Venture Diffractometer equipped with a GaKa I $\mu$ S source and MX optic.

b) Crystal parameters

$\left[\mathrm{C}_{55} \mathrm{H}_{54} \mathrm{~F}_{30} \mathrm{~N}_{15} \mathrm{O}_{3} \mathrm{P}_{5}\right]$, yellow block $(0.08 \times 0.06 \times 0.06 \mathrm{~mm})$, monoclinic, space group P1 $21 / \mathrm{n} \mathrm{1}, a=15.5909(9) \AA, b=26.5832(17) \AA, c=16.8096(11) \AA, \alpha=90^{\circ}, \beta=103.133(3)^{\circ}$, $V=90^{\circ}, V=6784.6(7) \AA^{3}, Z=4, T=195 \mathrm{~K}, \rho_{\text {calc }}=1.662 \mathrm{~g} / \mathrm{cm}^{3}, \mu(\mathrm{GaK \alpha})=1.34139 \mathrm{~mm}^{-1}$. A total of 12886 reflections were collected, of which 9162 were unique. Final $R_{1}(I>2 \sigma(I))$ $=0.1251$ and $w R_{2}=0.2933$ (all data). The structure was solved by direct method and different Fourier syntheses. Using Olex2, the structure was solved with the ShelXT structure solution program using Intrinsic Phasing and refined with the ShelXL refinement package using Least Squares minimization. CCDC number: 2014364.

c) Solid-state structure 
a)

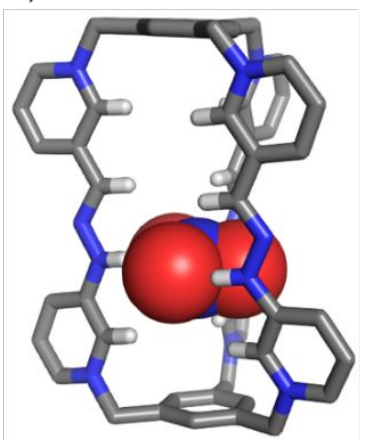

b)

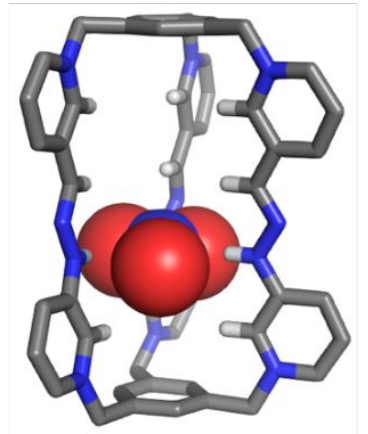

c)

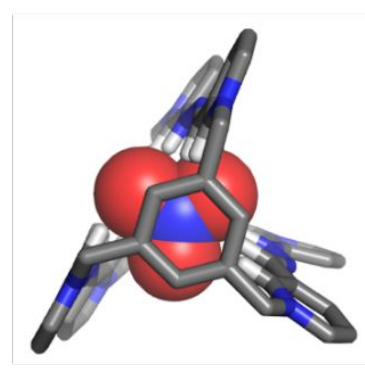

Figure S67. Different views of the solid-state structure of $\mathrm{NO}_{3}{ }^{-} \subset 3^{6+} \cdot 5 \mathrm{PF}_{6}{ }^{-}$. Color codes: Carbon, grey; nitrogen, blue; hydrogen, white; oxygen, red. Disordered solvent molecules, other counterions, and hydrogen atoms which are not involved in hydrogen bonding interactions are omitted for clarity.

Cartesian coordinates of cages

$\mathrm{Cl}^{-} \subset 3^{6+} \cdot 5 \mathrm{PF}_{6}{ }^{-}:$

51

$\mathrm{N}$

$\mathrm{N}$

$\mathrm{N}$

$\mathrm{H}$

$\mathrm{N}$

$\mathrm{N}$

$\mathrm{N}$

$\mathrm{H}$

$\mathrm{N}$

$\mathrm{N}$

$\mathrm{N}$

$\mathrm{N}$

$\mathrm{N}$

$\mathrm{H}$

$\mathrm{N}$

C

C

$\mathrm{H}$

C

C

$\mathrm{H}$

C

C

$\mathrm{H}$

C

$\mathrm{H}$

$\mathrm{H}$
$-0.38800000$

4.29850000

5.30400000

5.13150000

8.93250000

8.25430000

4.78580000

4.61950000

3.82070000

$-0.75230000$

$-1.70320000$

2.87390000

4.13240000

4.29310000

7.52970000

$-1.91220000$

$-1.88120000$

$-1.71490000$

$-2.08610000$

$-2.36520000$

$-2.53940000$

$-2.39260000$

$-2.14520000$

$-2.13290000$

$-1.77880000$

$-2.34470000$

$-2.13190000$
21.38640000

20.73550000

19.83760000

18.97520000

19.77370000

14.45110000

15.58410000

15.70610000

15.78970000

16.90530000

15.85660000

15.10170000

15.07600000

15.06790000

15.18560000

19.38120000

19.02280000

19.68880000

17.70460000

16.75800000

15.85700000

17.11170000

18.41560000

18.65150000

20.84380000

21.39090000

20.94980000
12.06580000

11.83310000

11.82480000

11.85860000

11.97170000

9.70910000

9.48630000

10.34160000

8.59180000

7.98440000

14.35650000

15.26090000

14.79880000

13.93430000

16.10920000

11.69770000

10.36760000

9.70990000

9.96650000

10.95340000

10.70260000

12.28860000

12.66160000

13.58130000

12.10370000

11.50260000

13.02260000 


\begin{tabular}{|c|c|c|c|}
\hline C & -0.26660000 & 22.69690000 & 12.24900000 \\
\hline $\mathrm{H}$ & -1.04230000 & 23.23250000 & 12.36650000 \\
\hline C & 0.97860000 & 23.27720000 & 12.26550000 \\
\hline $\mathrm{H}$ & 1.06340000 & 24.21440000 & 12.38840000 \\
\hline C & 2.12360000 & 22.48570000 & 12.10210000 \\
\hline $\mathrm{H}$ & 2.98830000 & 22.87900000 & 12.10290000 \\
\hline C & 1.97420000 & 21.14760000 & 11.94530000 \\
\hline C & 0.69190000 & 20.60260000 & 11.93370000 \\
\hline $\mathrm{H}$ & 0.58110000 & 19.66470000 & 11.82910000 \\
\hline C & 3.09820000 & 20.24490000 & 11.82480000 \\
\hline $\mathrm{H}$ & 2.95920000 & 19.30960000 & 11.74090000 \\
\hline C & 6.61500000 & 20.29300000 & 11.76050000 \\
\hline C & 6.95870000 & 21.58190000 & 11.42050000 \\
\hline $\mathrm{H}$ & 6.28650000 & 22.22000000 & 11.20920000 \\
\hline C & 8.28580000 & 21.93210000 & 11.39410000 \\
\hline $\mathrm{H}$ & 8.52690000 & 22.82510000 & 11.18310000 \\
\hline C & 9.27700000 & 21.01230000 & 11.66800000 \\
\hline $\mathrm{H}$ & 10.19130000 & 21.26540000 & 11.63910000 \\
\hline C & 7.65040000 & 19.39880000 & 12.01960000 \\
\hline $\mathrm{H}$ & 7.43950000 & 18.49800000 & 12.23540000 \\
\hline C & 10.06480000 & 18.83030000 & 12.22420000 \\
\hline $\mathrm{H}$ & 10.60640000 & 19.18120000 & 12.97450000 \\
\hline $\mathrm{H}$ & 10.64390000 & 18.81060000 & 11.42140000 \\
\hline C & 9.65040000 & 17.41390000 & 12.55260000 \\
\hline C & 9.58780000 & 16.45580000 & 11.55580000 \\
\hline $\mathrm{H}$ & 9.75870000 & 16.70320000 & 10.65370000 \\
\hline C & 9.27490000 & 15.12600000 & 11.86440000 \\
\hline C & 9.04460000 & 14.78940000 & 13.18470000 \\
\hline $\mathrm{H}$ & 8.84450000 & 13.88740000 & 13.40530000 \\
\hline C & 9.09910000 & 15.74180000 & 14.19640000 \\
\hline C & 9.38690000 & 17.04670000 & 13.87460000 \\
\hline $\mathrm{H}$ & 9.40790000 & 17.70500000 & 14.55750000 \\
\hline C & 9.22190000 & 14.08660000 & 10.79330000 \\
\hline $\mathrm{H}$ & 8.95340000 & 13.22050000 & 11.19210000 \\
\hline $\mathrm{H}$ & 10.12340000 & 13.97510000 & 10.40160000 \\
\hline C & 8.62770000 & 14.33260000 & 8.42510000 \\
\hline $\mathrm{H}$ & 9.50330000 & 14.03980000 & 8.20650000 \\
\hline C & 7.72800000 & 14.64280000 & 7.42500000 \\
\hline $\mathrm{H}$ & 7.99070000 & 14.56120000 & 6.51660000 \\
\hline C & 6.44310000 & 15.07600000 & 7.73190000 \\
\hline $\mathrm{H}$ & 5.83050000 & 15.30170000 & 7.04200000 \\
\hline C & 6.07150000 & 15.17230000 & 9.08190000 \\
\hline C & 7.01210000 & 14.84870000 & 10.03420000 \\
\hline $\mathrm{H}$ & 6.77500000 & 14.90730000 & 10.95140000 \\
\hline
\end{tabular}




\begin{tabular}{|c|c|c|c|}
\hline C & 2.69280000 & 16.23920000 & 9.07700000 \\
\hline $\mathrm{H}$ & 2.61750000 & 16.45310000 & 9.99950000 \\
\hline C & 1.56990000 & 16.40950000 & 8.20230000 \\
\hline C & 1.64880000 & 16.19110000 & 6.84070000 \\
\hline $\mathrm{H}$ & 2.47450000 & 15.94930000 & 6.43710000 \\
\hline C & 0.51450000 & 16.33010000 & 6.08160000 \\
\hline $\mathrm{H}$ & 0.56400000 & 16.21470000 & 5.13980000 \\
\hline C & -0.69120000 & 16.62960000 & 6.66580000 \\
\hline $\mathrm{H}$ & -1.48340000 & 16.64520000 & 6.14070000 \\
\hline C & 0.34830000 & 16.80070000 & 8.72710000 \\
\hline $\mathrm{H}$ & 0.29410000 & 17.00230000 & 9.65390000 \\
\hline C & -2.09350000 & 17.32750000 & 8.52580000 \\
\hline $\mathrm{H}$ & -2.41890000 & 18.09990000 & 7.99790000 \\
\hline $\mathrm{H}$ & -2.73590000 & 16.58560000 & 8.39620000 \\
\hline C & -2.76760000 & 16.08140000 & 13.33820000 \\
\hline $\mathrm{H}$ & -3.59290000 & 16.37910000 & 13.79730000 \\
\hline $\mathrm{H}$ & -2.96720000 & 15.22320000 & 12.88660000 \\
\hline C & -2.04080000 & 15.77660000 & 15.62720000 \\
\hline $\mathrm{H}$ & -2.94090000 & 15.92460000 & 15.89280000 \\
\hline C & -1.07200000 & 15.47710000 & 16.57290000 \\
\hline $\mathrm{H}$ & -1.31870000 & 15.39260000 & 17.48720000 \\
\hline C & 0.23180000 & 15.30600000 & 16.20490000 \\
\hline $\mathrm{H}$ & 0.90130000 & 15.14450000 & 16.85940000 \\
\hline C & 0.56520000 & 15.36750000 & 14.85820000 \\
\hline C & -0.43000000 & 15.63490000 & 13.94550000 \\
\hline $\mathrm{H}$ & -0.22330000 & 15.66310000 & 13.01820000 \\
\hline C & 1.91740000 & 15.20440000 & 14.37630000 \\
\hline $\mathrm{H}$ & 2.10550000 & 15.17430000 & 13.44510000 \\
\hline C & 5.18510000 & 15.05810000 & 15.72630000 \\
\hline C & 4.97290000 & 14.85940000 & 17.08290000 \\
\hline $\mathrm{H}$ & 4.09230000 & 14.76910000 & 17.42900000 \\
\hline C & 6.07810000 & 14.79790000 & 17.92620000 \\
\hline $\mathrm{H}$ & 5.95510000 & 14.64760000 & 18.85570000 \\
\hline C & 7.33930000 & 14.95300000 & 17.42610000 \\
\hline $\mathrm{H}$ & 8.08720000 & 14.89820000 & 18.00930000 \\
\hline C & 6.48080000 & 15.23910000 & 15.25920000 \\
\hline $\mathrm{H}$ & 6.62950000 & 15.40480000 & 14.33630000 \\
\hline C & 8.94580000 & 15.37020000 & 15.64870000 \\
\hline $\mathrm{H}$ & 9.44190000 & 14.52930000 & 15.81280000 \\
\hline $\mathrm{H}$ & 9.36640000 & 16.07660000 & 16.20100000 \\
\hline $\mathrm{Cl}$ & 5.02790000 & 16.72510000 & 12.31940000 \\
\hline $\mathrm{Cl}$ & 2.44650000 & 17.21120000 & 12.01130000 \\
\hline
\end{tabular}


$\left(\mathrm{Cl}^{-}\right)_{2} \subset 3^{6+} \cdot 4 \mathrm{PF}_{6}{ }^{-}:$

41

$\mathrm{Cl}$

$\mathrm{Cl}$

3.03950000

17.35080000

11.95000000

6.23460000

16.85370000

12.26450000

$\mathrm{N}$

0.67730000

21.42050000

11.92040000

$\mathrm{N}$

0.25230000

16.72480000

8.20310000

$\mathrm{N}$

$-0.37200000$

16.00940000

14.72860000

$\mathrm{N}$

5.35770000

20.84390000

11.75840000

$\mathrm{N}$

6.36040000

19.98170000

11.81960000

$\mathrm{H}$

6.20570000

19.12130000

11.92120000

$\mathrm{N}$

9.97740000

19.95500000

11.75510000

$\mathrm{N}$

4.84580000

15.66500000

8.61140000

5.86230000

15.55820000

9.46920000

5.75260000

15.77930000

10.31370000

9.31620000

14.43430000

9.60470000

4.25130000

15.42740000

15.46910000

5.46540000

15.56620000

14.95500000

5.56760000

15.84080000

14.12510000

8.94280000

15.29120000

15.93350000

$-0.69290000$

20.89730000

12.07910000

$-1.29500000$

21.37450000

11.45420000

$-1.00470000$

21.08410000

13.00040000

$-0.78900000$

19.39170000

11.81460000

$-0.96420000$

18.52140000

12.84760000

$-0.93790000$

18.84340000

13.74180000

$-1.17690000$

17.19200000

12.61620000

$-1.14920000$

16.71950000

11.31050000

$-1.25400000$

15.78940000

11.14760000

$-0.97080000$

17.59240000

10.22790000

$-0.78030000$

18.91920000

10.51220000

$-0.63630000$

19.53070000

9.79810000

$-1.06470000$

17.09050000

8.80970000

$-1.65620000$

16.29700000

8.79100000

$-1.48730000$

17.79190000

8.25140000

$-1.49570000$

16.24960000

13.73520000

$-1.75800000$

15.37860000

13.34440000

$-2.27780000$

16.60290000

14.22680000

1.75420000

20.67570000

11.90390000

1.65190000

19.73090000

11.94210000

3.02990000

21.19900000

11.83440000

3.14140000

22.54980000

11.81460000

3.99770000

22.95740000

11.75000000

1.99750000

23.33730000

11.89230000 


\begin{tabular}{|c|c|c|c|}
\hline $\mathrm{H}$ & 2.06860000 & 24.28360000 & 11.92080000 \\
\hline C & 0.76170000 & 22.73130000 & 11.92530000 \\
\hline $\mathrm{H}$ & -0.02830000 & 23.25820000 & 11.95170000 \\
\hline C & 4.14550000 & 20.35540000 & 11.82780000 \\
\hline $\mathrm{H}$ & 4.02100000 & 19.41590000 & 11.87330000 \\
\hline C & 7.66680000 & 20.46480000 & 11.72200000 \\
\hline C & 7.95610000 & 21.76490000 & 11.51710000 \\
\hline $\mathrm{H}$ & 7.25530000 & 22.39370000 & 11.38360000 \\
\hline C & 9.28860000 & 22.18670000 & 11.49890000 \\
\hline $\mathrm{H}$ & 9.50050000 & 23.11130000 & 11.44640000 \\
\hline C & 10.31560000 & 21.22300000 & 11.56340000 \\
\hline $\mathrm{H}$ & 11.22710000 & 21.47350000 & 11.46940000 \\
\hline C & 8.70660000 & 19.54920000 & 11.83280000 \\
\hline $\mathrm{H}$ & 8.51370000 & 18.62850000 & 11.96340000 \\
\hline C & 11.12970000 & 19.00190000 & 11.84930000 \\
\hline $\mathrm{H}$ & 11.58000000 & 18.96810000 & 10.96820000 \\
\hline $\mathrm{H}$ & 11.78070000 & 19.36220000 & 12.50250000 \\
\hline C & 10.77360000 & 17.61380000 & 12.25260000 \\
\hline C & 10.67650000 & 16.61530000 & 11.29730000 \\
\hline $\mathrm{H}$ & 10.78960000 & 16.82390000 & 10.37700000 \\
\hline C & 10.41320000 & 15.29120000 & 11.69060000 \\
\hline C & 10.24870000 & 14.96820000 & 13.01950000 \\
\hline $\mathrm{H}$ & 10.06420000 & 14.07460000 & 13.28020000 \\
\hline C & 10.36000000 & 15.99070000 & 13.98310000 \\
\hline C & 10.61110000 & 17.28810000 & 13.58810000 \\
\hline $\mathrm{H}$ & 10.67370000 & 17.97030000 & 14.24560000 \\
\hline C & 10.30190000 & 15.65160000 & 15.43270000 \\
\hline $\mathrm{H}$ & 10.63630000 & 16.42510000 & 15.95130000 \\
\hline $\mathrm{H}$ & 10.91270000 & 14.89060000 & 15.60340000 \\
\hline C & 10.33530000 & 14.17000000 & 10.65260000 \\
\hline $\mathrm{H}$ & 11.22100000 & 14.06220000 & 10.22360000 \\
\hline $\mathrm{H}$ & 10.11520000 & 13.31890000 & 11.10990000 \\
\hline C & 9.60120000 & 14.15670000 & 8.31720000 \\
\hline $\mathrm{H}$ & 10.47000000 & 13.85780000 & 8.07480000 \\
\hline C & 8.63950000 & 14.30880000 & 7.36680000 \\
\hline $\mathrm{H}$ & 8.82930000 & 14.07900000 & 6.46470000 \\
\hline C & 7.38250000 & 14.79740000 & 7.70060000 \\
\hline $\mathrm{H}$ & 6.72080000 & 14.92390000 & 7.03110000 \\
\hline C & 7.11230000 & 15.09370000 & 9.01300000 \\
\hline C & 8.09720000 & 14.88550000 & 9.95350000 \\
\hline $\mathrm{H}$ & 7.91120000 & 15.06240000 & 10.86860000 \\
\hline C & 3.70420000 & 16.09740000 & 9.11710000 \\
\hline $\mathrm{H}$ & 3.64980000 & 16.31190000 & 10.04170000 \\
\hline C & 2.56380000 & 16.24160000 & 8.29900000 \\
\hline
\end{tabular}




\begin{tabular}{lrrr}
$\mathrm{C}$ & 2.59830000 & 16.00670000 & 6.93040000 \\
$\mathrm{H}$ & 3.39840000 & 15.74640000 & 6.49000000 \\
$\mathrm{C}$ & 1.42000000 & 16.16690000 & 6.24450000 \\
$\mathrm{H}$ & 1.41300000 & 16.03840000 & 5.30310000 \\
$\mathrm{C}$ & 0.24980000 & 16.50860000 & 6.88250000 \\
$\mathrm{H}$ & -0.55760000 & 16.58860000 & 6.38760000 \\
$\mathrm{C}$ & 1.38200000 & 16.58330000 & 8.90230000 \\
$\mathrm{H}$ & 1.36630000 & 16.72380000 & 9.84090000 \\
$\mathrm{C}$ & 0.90650000 & 15.97730000 & 14.29720000 \\
$\mathrm{H}$ & 1.10110000 & 16.16880000 & 13.38660000 \\
$\mathrm{C}$ & 1.92720000 & 15.67300000 & 15.15830000 \\
$\mathrm{C}$ & 1.63210000 & 15.45680000 & 16.47070000 \\
$\mathrm{H}$ & 2.32500000 & 15.29960000 & 17.10030000 \\
$\mathrm{C}$ & 0.31370000 & 15.47010000 & 16.87070000 \\
$\mathrm{H}$ & 0.09840000 & 15.28900000 & 17.77840000 \\
$\mathrm{C}$ & -0.68450000 & 15.73970000 & 15.98480000 \\
$\mathrm{H}$ & -1.59180000 & 15.73380000 & 16.26460000 \\
$\mathrm{C}$ & 3.23700000 & 15.69700000 & 14.65590000 \\
$\mathrm{H}$ & 3.39650000 & 15.90210000 & 13.74290000 \\
$\mathrm{C}$ & 6.57280000 & 15.27790000 & 15.73680000 \\
$\mathrm{C}$ & 6.47110000 & 14.70660000 & 16.99130000 \\
$\mathrm{H}$ & 5.62340000 & 14.51370000 & 17.37450000 \\
$\mathrm{C}$ & 7.65850000 & 14.42100000 & 17.67890000 \\
$\mathrm{H}$ & 7.62070000 & 14.00030000 & 18.52980000 \\
$\mathrm{C}$ & 8.83860000 & 14.73060000 & 17.14510000 \\
$\mathrm{H}$ & 9.62980000 & 14.54920000 & 17.63940000 \\
$\mathrm{C}$ & 7.82880000 & 15.55550000 & 15.23270000 \\
$\mathrm{H}$ & 7.90600000 & 15.94160000 & 14.36730000 \\
& & & \\
\hline & & &
\end{tabular}

$\mathrm{NO}_{3}{ }^{-} \subset 3^{6+} \cdot 5 \mathrm{PF}_{6}{ }^{-}:$

51

$\begin{array}{llll}\mathrm{O} & 6.63280000 & 17.05840000 & 5.29730000 \\ \mathrm{O} & 7.17730000 & 15.13380000 & 4.32000000 \\ \mathrm{O} & 6.82480000 & 16.95740000 & 3.07760000 \\ \mathrm{~N} & 6.84040000 & 16.44170000 & 4.20710000 \\ \mathrm{~N} & 2.88280000 & 19.48020000 & 4.49030000 \\ \mathrm{~N} & 3.57280000 & 14.30710000 & 6.78530000 \\ \mathrm{~N} & 4.27710000 & 14.95570000 & 0.43220000 \\ \mathrm{~N} & 6.48690000 & 19.48810000 & 4.71290000 \\ \mathrm{H} & 6.65480000 & 18.62530000 & 4.71340000 \\ \mathrm{~N} & 7.48070000 & 20.38670000 & 4.68340000 \\ \mathrm{~N} & 7.03510000 & 15.28270000 & 6.94740000 \\ \mathrm{H} & 7.23830000 & 15.22350000 & 6.09330000 \\ \mathrm{~N} & 7.96970000 & 15.63620000 & 7.81990000\end{array}$




\begin{tabular}{|c|c|c|c|}
\hline$N$ & 7.65450000 & 14.83610000 & 1.73360000 \\
\hline $\mathrm{H}$ & 7.50060000 & 14.69870000 & 2.58930000 \\
\hline$N$ & 8.89720000 & 14.98230000 & 1.27850000 \\
\hline$N$ & 12.11300000 & 21.12170000 & 4.40840000 \\
\hline $\mathrm{N}$ & 12.47650000 & 16.84050000 & 8.52380000 \\
\hline$N$ & 13.42630000 & 15.68410000 & 2.23450000 \\
\hline C & 1.75000000 & 18.56300000 & 4.22670000 \\
\hline $\mathrm{H}$ & 1.23500000 & 18.91100000 & 3.45620000 \\
\hline $\mathrm{H}$ & 1.14880000 & 18.56890000 & 5.01390000 \\
\hline C & 2.14190000 & 17.14620000 & 3.93700000 \\
\hline C & 2.20020000 & 16.21840000 & 4.95030000 \\
\hline $\mathrm{H}$ & 2.02580000 & 16.47620000 & 5.84700000 \\
\hline C & 2.52220000 & 14.88930000 & 4.64580000 \\
\hline C & 2.73770000 & 14.51710000 & 3.32800000 \\
\hline $\mathrm{H}$ & 2.92620000 & 13.60880000 & 3.12310000 \\
\hline C & 2.68020000 & 15.44750000 & 2.31140000 \\
\hline C & 2.39370000 & 16.75540000 & 2.61760000 \\
\hline $\mathrm{H}$ & 2.36390000 & 17.40350000 & 1.92470000 \\
\hline C & 2.86210000 & 15.03280000 & 0.89050000 \\
\hline $\mathrm{H}$ & 2.44370000 & 14.14310000 & 0.76680000 \\
\hline $\mathrm{H}$ & 2.37760000 & 15.67210000 & 0.31010000 \\
\hline C & 2.60700000 & 13.87640000 & 5.74590000 \\
\hline $\mathrm{H}$ & 1.71410000 & 13.75700000 & 6.15430000 \\
\hline $\mathrm{H}$ & 2.89270000 & 13.00610000 & 5.37030000 \\
\hline C & 3.19440000 & 14.38420000 & 8.03270000 \\
\hline $\mathrm{H}$ & 2.29960000 & 14.17130000 & 8.27080000 \\
\hline C & 4.09010000 & 14.77230000 & 9.00510000 \\
\hline $\mathrm{H}$ & 3.81530000 & 14.81440000 & 9.91300000 \\
\hline C & 5.36540000 & 15.09660000 & 8.66460000 \\
\hline $\mathrm{H}$ & 5.98130000 & 15.37940000 & 9.33120000 \\
\hline C & 5.75590000 & 15.01150000 & 7.35830000 \\
\hline C & 4.83280000 & 14.60480000 & 6.44320000 \\
\hline $\mathrm{H}$ & 5.09160000 & 14.52910000 & 5.53190000 \\
\hline C & 9.13560000 & 16.04030000 & 7.35340000 \\
\hline $\mathrm{H}$ & 9.26320000 & 16.16350000 & 6.41950000 \\
\hline C & 10.20090000 & 16.28750000 & 8.26030000 \\
\hline C & 10.04790000 & 16.18390000 & 9.60420000 \\
\hline $\mathrm{H}$ & 9.20010000 & 15.98620000 & 9.98520000 \\
\hline C & 11.12120000 & 16.36990000 & 10.37690000 \\
\hline $\mathrm{H}$ & 11.03620000 & 16.28060000 & 11.31820000 \\
\hline C & 12.32650000 & 16.68360000 & 9.84820000 \\
\hline $\mathrm{H}$ & 13.07590000 & 16.79320000 & 10.42190000 \\
\hline C & 11.42930000 & 16.63840000 & 7.73970000 \\
\hline $\mathrm{H}$ & 11.52590000 & 16.73490000 & 6.8000000 \\
\hline
\end{tabular}




\begin{tabular}{|c|c|c|c|}
\hline C & 13.82390000 & 17.22330000 & 8.03440000 \\
\hline $\mathrm{H}$ & 14.44880000 & 16.47310000 & 8.20020000 \\
\hline $\mathrm{H}$ & 14.14300000 & 18.00120000 & 8.55650000 \\
\hline C & 13.86210000 & 17.57420000 & 6.56110000 \\
\hline C & 13.64810000 & 18.86080000 & 6.14200000 \\
\hline $\mathrm{H}$ & 13.48320000 & 19.54040000 & 6.78480000 \\
\hline C & 13.66770000 & 19.19040000 & 4.78820000 \\
\hline C & 13.90960000 & 18.19890000 & 3.86490000 \\
\hline $\mathrm{H}$ & 13.91280000 & 18.40940000 & 2.93910000 \\
\hline C & 14.14890000 & 16.88830000 & 4.26930000 \\
\hline C & 14.12890000 & 16.59590000 & 5.61820000 \\
\hline $\mathrm{H}$ & 14.30260000 & 15.70710000 & 5.90490000 \\
\hline C & 13.49830000 & 20.60460000 & 4.33800000 \\
\hline $\mathrm{H}$ & 14.07850000 & 21.18430000 & 4.89430000 \\
\hline $\mathrm{H}$ & 13.81500000 & 20.67850000 & 3.40260000 \\
\hline C & 14.47120000 & 15.83300000 & 3.28870000 \\
\hline $\mathrm{H}$ & 14.57450000 & 14.97090000 & 3.76540000 \\
\hline $\mathrm{H}$ & 15.33630000 & 16.04630000 & 2.85840000 \\
\hline C & 11.96410000 & 22.41500000 & 4.24470000 \\
\hline $\mathrm{H}$ & 12.71690000 & 22.97370000 & 4.09340000 \\
\hline C & 10.67030000 & 22.95460000 & 4.29710000 \\
\hline $\mathrm{H}$ & 10.55080000 & 23.89500000 & 4.22440000 \\
\hline C & 9.58520000 & 22.14910000 & 4.45100000 \\
\hline $\mathrm{H}$ & 8.71040000 & 22.51870000 & 4.47620000 \\
\hline C & 9.76850000 & 20.81730000 & 4.56720000 \\
\hline C & 11.05980000 & 20.31750000 & 4.55250000 \\
\hline $\mathrm{H}$ & 11.19760000 & 19.38120000 & 4.64650000 \\
\hline C & 8.68860000 & 19.89490000 & 4.68510000 \\
\hline $\mathrm{H}$ & 8.84260000 & 18.96010000 & 4.75960000 \\
\hline C & 5.17820000 & 19.97200000 & 4.74240000 \\
\hline C & 4.84960000 & 21.26920000 & 5.06810000 \\
\hline $\mathrm{H}$ & 5.52650000 & 21.89840000 & 5.28960000 \\
\hline C & 3.54510000 & 21.63340000 & 5.06650000 \\
\hline $\mathrm{H}$ & 3.30960000 & 22.53040000 & 5.27420000 \\
\hline C & 2.55830000 & 20.72960000 & 4.77180000 \\
\hline $\mathrm{H}$ & 1.64680000 & 20.99900000 & 4.77020000 \\
\hline C & 4.14450000 & 19.08140000 & 4.49520000 \\
\hline $\mathrm{H}$ & 4.34540000 & 18.16860000 & 4.32640000 \\
\hline C & 6.61220000 & 14.90250000 & 0.82830000 \\
\hline C & 6.82870000 & 14.85200000 & -0.50750000 \\
\hline $\mathrm{H}$ & 7.71410000 & 14.83740000 & -0.84990000 \\
\hline C & 5.75000000 & 14.82550000 & -1.36360000 \\
\hline $\mathrm{H}$ & 5.89090000 & 14.75810000 & -2.29980000 \\
\hline C & 4.46500000 & 14.89460000 & -0.86760000 \\
\hline
\end{tabular}




$\begin{array}{lrrr}\text { H } & 3.72290000 & 14.89800000 & -1.45940000 \\ \mathrm{C} & 5.31010000 & 14.97170000 & 1.27690000 \\ \mathrm{H} & 5.14500000 & 15.03180000 & 2.21070000 \\ \mathrm{C} & 9.85950000 & 15.02480000 & 2.15920000 \\ \mathrm{H} & 9.67850000 & 14.91430000 & 3.08490000 \\ \mathrm{C} & 11.19070000 & 15.24280000 & 1.69270000 \\ \mathrm{C} & 11.48370000 & 15.32790000 & 0.37000000 \\ \mathrm{H} & 10.80320000 & 15.25430000 & -0.28770000 \\ \mathrm{C} & 12.79360000 & 15.52190000 & 0.01470000 \\ \mathrm{H} & 13.03630000 & 15.52690000 & -0.90390000 \\ \mathrm{C} & 13.75780000 & 15.71330000 & 0.97400000 \\ \mathrm{H} & 14.66010000 & 15.86540000 & 0.72110000 \\ \mathrm{C} & 12.18990000 & 15.43950000 & 2.62900000 \\ \mathrm{H} & 11.98570000 & 15.40060000 & 3.55560000 \\ \text { ?s } & 9.08460000 & 18.28920000 & 0.76940000\end{array}$

$\left(\mathrm{Cl}^{-} \cdot \mathrm{Br}^{-}\right) \subset 3^{6+} \cdot 4 \mathrm{PF}_{6}{ }^{-}$:

41

$\begin{array}{lrrr}\mathrm{Br} & 6.72860000 & 9.77550000 & 4.22640000 \\ \mathrm{Cl} & 9.61280000 & 9.28800000 & 4.52520000 \\ \mathrm{~N} & 2.90710000 & 6.68480000 & 4.70020000 \\ \mathrm{~N} & 3.55920000 & 12.15530000 & 6.91900000 \\ \mathrm{~N} & 3.94340000 & 11.35030000 & 0.57120000 \\ \mathrm{~N} & 7.52420000 & 5.78670000 & 4.67380000 \\ \mathrm{~N} & 8.75520000 & 6.29150000 & 4.65730000 \\ \mathrm{H} & 8.87190000 & 7.16230000 & 4.67060000 \\ \mathrm{~N} & 8.03100000 & 10.99690000 & 7.86500000 \\ \mathrm{~N} & 9.17560000 & 10.59040000 & 7.33510000 \\ \mathrm{H} & 9.21900000 & 10.40280000 & 6.47600000 \\ \mathrm{~N} & 8.61570000 & 11.26260000 & 1.04010000 \\ \mathrm{~N} & 9.64780000 & 11.00490000 & 1.85730000 \\ \mathrm{H} & 9.51140000 & 10.83940000 & 2.71000000 \\ \mathrm{~N} & 12.20940000 & 5.22350000 & 4.53180000 \\ \mathrm{~N} & 12.62860000 & 10.02450000 & 8.24970000 \\ \mathrm{~N} & 13.23720000 & 10.62760000 & 1.74830000 \\ \mathrm{C} & 1.74540000 & 7.60670000 & 4.63250000 \\ \mathrm{H} & 1.30310000 & 7.62470000 & 5.51830000 \\ \mathrm{H} & 1.09350000 & 7.24870000 & 3.97970000 \\ \mathrm{C} & 2.09140000 & 9.01220000 & 4.24290000 \\ \mathrm{C} & 2.18470000 & 9.99260000 & 5.19550000 \\ \mathrm{H} & 2.06330000 & 9.77510000 & 6.11250000 \\ \mathrm{C} & 2.45450000 & 11.30510000 & 4.82730000 \\ \mathrm{C} & 2.62640000 & 11.63460000 & 3.48680000\end{array}$




\begin{tabular}{|c|c|c|c|}
\hline $\mathrm{H}$ & 2.81480000 & 12.53050000 & 3.23750000 \\
\hline C & 2.52110000 & 10.64090000 & 2.50280000 \\
\hline C & 2.26330000 & 9.34700000 & 2.89240000 \\
\hline $\mathrm{H}$ & 2.20060000 & 8.66490000 & 2.23400000 \\
\hline C & 2.59190000 & 11.01550000 & 1.06810000 \\
\hline $\mathrm{H}$ & 2.23690000 & 10.26450000 & 0.52890000 \\
\hline $\mathrm{H}$ & 2.00090000 & 11.79510000 & 0.91760000 \\
\hline C & 2.49620000 & 12.40240000 & 5.85090000 \\
\hline $\mathrm{H}$ & 1.61010000 & 12.47670000 & 6.28530000 \\
\hline $\mathrm{H}$ & 2.68490000 & 13.26300000 & 5.39740000 \\
\hline C & 3.27200000 & 12.42100000 & 8.17700000 \\
\hline $\mathrm{H}$ & 2.39980000 & 12.71030000 & 8.41760000 \\
\hline C & 4.24020000 & 12.27750000 & 9.14120000 \\
\hline $\mathrm{H}$ & 4.04140000 & 12.48160000 & 10.04690000 \\
\hline C & 5.49400000 & 11.83910000 & 8.79940000 \\
\hline $\mathrm{H}$ & 6.16490000 & 11.73000000 & 9.46310000 \\
\hline C & 5.76230000 & 11.56020000 & 7.48530000 \\
\hline C & 4.76120000 & 11.73020000 & 6.54260000 \\
\hline $\mathrm{H}$ & 4.93380000 & 11.54390000 & 5.62790000 \\
\hline C & 7.00730000 & 11.11910000 & 7.02470000 \\
\hline $\mathrm{H}$ & 7.12360000 & 10.90400000 & 6.10570000 \\
\hline C & 10.32360000 & 10.46020000 & 8.14400000 \\
\hline C & 10.31610000 & 10.69930000 & 9.50270000 \\
\hline $\mathrm{H}$ & 9.51610000 & 10.95770000 & 9.94450000 \\
\hline C & 11.50640000 & 10.55050000 & 10.21260000 \\
\hline $\mathrm{H}$ & 11.50960000 & 10.67490000 & 11.15510000 \\
\hline C & 12.66560000 & 10.22910000 & 9.57210000 \\
\hline $\mathrm{H}$ & 13.48060000 & 10.14940000 & 10.05330000 \\
\hline C & 11.51400000 & 10.09360000 & 7.54140000 \\
\hline $\mathrm{H}$ & 11.53160000 & 9.88960000 & 6.61430000 \\
\hline C & 13.94790000 & 9.66850000 & 7.61570000 \\
\hline $\mathrm{H}$ & 14.39560000 & 8.99090000 & 8.18090000 \\
\hline $\mathrm{H}$ & 14.52070000 & 10.47670000 & 7.60870000 \\
\hline C & 13.85390000 & 9.12910000 & 6.19430000 \\
\hline C & 13.66640000 & 7.76610000 & 5.97300000 \\
\hline $\mathrm{H}$ & 13.53020000 & 7.18220000 & 6.70980000 \\
\hline C & 13.67770000 & 7.25600000 & 4.68700000 \\
\hline C & 13.85370000 & 8.11680000 & 3.61060000 \\
\hline $\mathrm{H}$ & 13.83900000 & 7.78160000 & 2.72110000 \\
\hline C & 14.04860000 & 9.45590000 & 3.84330000 \\
\hline C & 14.04260000 & 9.96870000 & 5.08650000 \\
\hline $\mathrm{H}$ & 14.16750000 & 10.90100000 & 5.21500000 \\
\hline C & 14.37490000 & 10.39640000 & 2.67940000 \\
\hline $\mathrm{H}$ & 14.66830000 & 11.26690000 & 3.04680000 \\
\hline
\end{tabular}




\begin{tabular}{|c|c|c|c|}
\hline $\mathrm{H}$ & 15.13240000 & 10.01580000 & 2.16730000 \\
\hline C & 13.58300000 & 5.76550000 & 4.42780000 \\
\hline $\mathrm{H}$ & 13.93130000 & 5.57870000 & 3.52100000 \\
\hline $\mathrm{H}$ & 14.16220000 & 5.29350000 & 5.07650000 \\
\hline C & 12.12100000 & 3.92420000 & 4.43600000 \\
\hline $\mathrm{H}$ & 12.91650000 & 3.40680000 & 4.42190000 \\
\hline C & 10.89740000 & 3.28390000 & 4.35840000 \\
\hline $\mathrm{H}$ & 10.83780000 & 2.35260000 & 4.17220000 \\
\hline C & 9.75080000 & 4.06770000 & 4.55320000 \\
\hline $\mathrm{H}$ & 8.90190000 & 3.65250000 & 4.64300000 \\
\hline C & 9.85490000 & 5.44400000 & 4.61930000 \\
\hline C & 11.12920000 & 5.96210000 & 4.60280000 \\
\hline $\mathrm{H}$ & 11.23140000 & 6.90670000 & 4.64280000 \\
\hline C & 6.52830000 & 6.65290000 & 4.65400000 \\
\hline $\mathrm{H}$ & 6.70200000 & 7.58500000 & 4.58440000 \\
\hline C & 5.21360000 & 6.18260000 & 4.73810000 \\
\hline C & 4.91960000 & 4.85950000 & 4.90980000 \\
\hline $\mathrm{H}$ & 5.61980000 & 4.23450000 & 5.05750000 \\
\hline C & 3.59100000 & 4.41840000 & 4.86860000 \\
\hline $\mathrm{H}$ & 3.38400000 & 3.49030000 & 4.87510000 \\
\hline C & 2.60270000 & 5.35900000 & 4.82070000 \\
\hline $\mathrm{H}$ & 1.69330000 & 5.08880000 & 4.87050000 \\
\hline C & 4.16800000 & 7.06200000 & 4.63250000 \\
\hline $\mathrm{H}$ & 4.36020000 & 7.98390000 & 4.50470000 \\
\hline C & 4.02940000 & 11.84980000 & -0.67850000 \\
\hline $\mathrm{H}$ & 3.23800000 & 12.01930000 & -1.17690000 \\
\hline C & 5.25650000 & 12.11550000 & -1.22990000 \\
\hline $\mathrm{H}$ & 5.31590000 & 12.46120000 & -2.11240000 \\
\hline C & 6.39090000 & 11.88700000 & -0.51010000 \\
\hline $\mathrm{H}$ & 7.24210000 & 12.06260000 & -0.89300000 \\
\hline C & 6.29940000 & 11.40610000 & 0.75450000 \\
\hline C & 5.03640000 & 11.10320000 & 1.25970000 \\
\hline $\mathrm{H}$ & 4.96430000 & 10.71090000 & 2.12220000 \\
\hline C & 7.40430000 & 11.16430000 & 1.56180000 \\
\hline $\mathrm{H}$ & 7.29190000 & 10.93080000 & 2.47610000 \\
\hline C & 10.95010000 & 11.00750000 & 1.32900000 \\
\hline C & 11.23830000 & 11.23600000 & 0.02640000 \\
\hline $\mathrm{H}$ & 10.53960000 & 11.39750000 & -0.59600000 \\
\hline C & 12.55590000 & 11.22810000 & -0.39460000 \\
\hline $\mathrm{H}$ & 12.76980000 & 11.45400000 & -1.29260000 \\
\hline C & 13.53840000 & 10.90130000 & 0.47050000 \\
\hline $\mathrm{H}$ & 14.44070000 & 10.86650000 & 0.17540000 \\
\hline C & 11.97430000 & 10.70730000 & 2.17590000 \\
\hline $\mathrm{H}$ & 11.78460000 & 10.55000000 & 3.09400000 \\
\hline
\end{tabular}




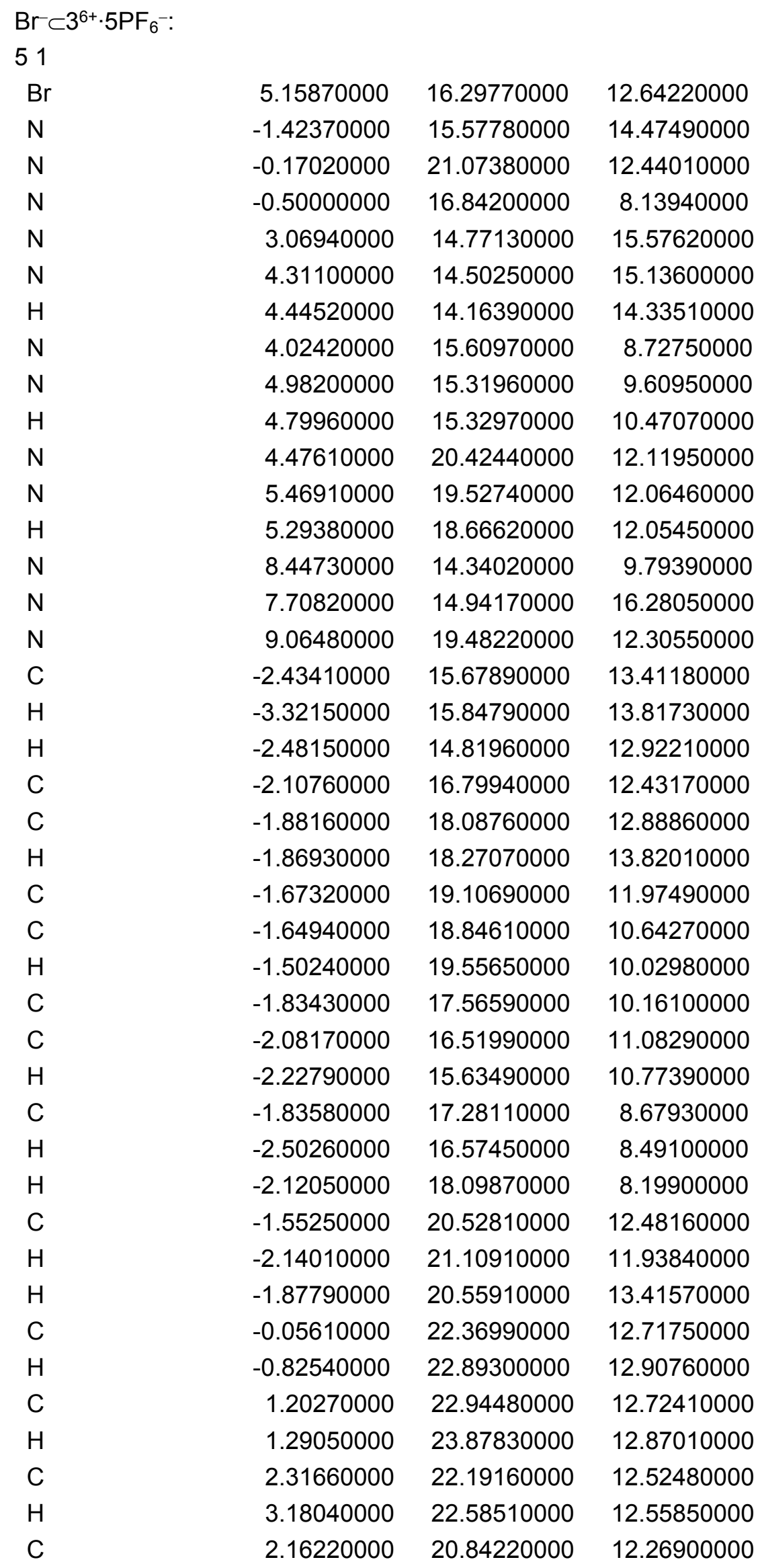




\begin{tabular}{|c|c|c|c|}
\hline C & 0.88900000 & 20.31790000 & 12.23570000 \\
\hline $\mathrm{H}$ & 0.77120000 & 19.39060000 & 12.06130000 \\
\hline C & 3.27550000 & 19.95330000 & 12.05800000 \\
\hline $\mathrm{H}$ & 3.12910000 & 19.03200000 & 11.87550000 \\
\hline C & 6.77970000 & 19.98790000 & 12.02480000 \\
\hline C & 7.11800000 & 21.26800000 & 11.71250000 \\
\hline $\mathrm{H}$ & 6.44270000 & 21.89880000 & 11.49270000 \\
\hline C & 8.43830000 & 21.64330000 & 11.71410000 \\
\hline $\mathrm{H}$ & 8.68380000 & 22.54070000 & 11.51820000 \\
\hline C & 9.39630000 & 20.70910000 & 12.00320000 \\
\hline $\mathrm{H}$ & 10.31270000 & 20.95720000 & 11.98570000 \\
\hline C & 7.79380000 & 19.10160000 & 12.33370000 \\
\hline $\mathrm{H}$ & 7.57760000 & 18.20720000 & 12.56940000 \\
\hline C & 10.18920000 & 18.55330000 & 12.60620000 \\
\hline $\mathrm{H}$ & 10.65860000 & 18.87900000 & 13.41440000 \\
\hline $\mathrm{H}$ & 10.83280000 & 18.58430000 & 11.85410000 \\
\hline C & 9.77870000 & 17.12680000 & 12.82880000 \\
\hline C & 9.74150000 & 16.25640000 & 11.77390000 \\
\hline $\mathrm{H}$ & 9.90940000 & 16.57190000 & 10.89440000 \\
\hline C & 9.45340000 & 14.90170000 & 11.98990000 \\
\hline C & 9.22010000 & 14.45460000 & 13.27230000 \\
\hline $\mathrm{H}$ & 9.01870000 & 13.53790000 & 13.41950000 \\
\hline C & 9.27650000 & 15.31430000 & 14.33870000 \\
\hline C & 9.54700000 & 16.65830000 & 14.11110000 \\
\hline $\mathrm{H}$ & 9.57150000 & 17.26160000 & 14.84440000 \\
\hline C & 9.10190000 & 14.80330000 & 15.75230000 \\
\hline $\mathrm{H}$ & 9.35910000 & 13.84730000 & 15.77810000 \\
\hline $\mathrm{H}$ & 9.71940000 & 15.29650000 & 16.34810000 \\
\hline C & 9.41850000 & 13.92500000 & 10.85200000 \\
\hline $\mathrm{H}$ & 10.32360000 & 13.85410000 & 10.45510000 \\
\hline $\mathrm{H}$ & 9.16560000 & 13.03210000 & 11.19490000 \\
\hline C & 8.84290000 & 14.32150000 & 8.51320000 \\
\hline $\mathrm{H}$ & 9.73180000 & 14.08030000 & 8.27890000 \\
\hline C & 7.92810000 & 14.66490000 & 7.54640000 \\
\hline $\mathrm{H}$ & 8.19310000 & 14.65060000 & 6.63510000 \\
\hline C & 6.62960000 & 15.02680000 & 7.86200000 \\
\hline $\mathrm{H}$ & 6.01740000 & 15.28750000 & 7.18430000 \\
\hline C & 6.25440000 & 15.00020000 & 9.18430000 \\
\hline C & 7.18850000 & 14.65950000 & 10.14110000 \\
\hline $\mathrm{H}$ & 6.93800000 & 14.64820000 & 11.05710000 \\
\hline C & 2.87870000 & 15.99560000 & 9.22580000 \\
\hline $\mathrm{H}$ & 2.78190000 & 16.10390000 & 10.16380000 \\
\hline C & 1.76370000 & 16.25110000 & 8.35370000 \\
\hline C & 1.88390000 & 16.14470000 & 6.99160000 \\
\hline
\end{tabular}




$\begin{array}{lrrr}\text { H } & 2.70900000 & 15.90190000 & 6.59050000 \\ \mathrm{C} & 0.79400000 & 16.39750000 & 6.24080000 \\ \mathrm{H} & 0.86560000 & 16.35890000 & 5.29410000 \\ \mathrm{C} & -0.42920000 & 16.71160000 & 6.81220000 \\ \mathrm{H} & -1.20020000 & 16.83320000 & 6.27200000 \\ \mathrm{C} & 0.55900000 & 16.60510000 & 8.89690000 \\ \mathrm{H} & 0.48060000 & 16.68180000 & 9.84110000 \\ \mathrm{C} & 7.56110000 & 15.25570000 & 17.55130000 \\ \mathrm{H} & 8.32560000 & 15.41000000 & 18.09350000 \\ \mathrm{C} & 6.28680000 & 15.35950000 & 18.10110000 \\ \mathrm{H} & 6.17100000 & 15.59900000 & 19.01270000 \\ \mathrm{C} & 5.19110000 & 15.10930000 & 17.29050000 \\ \mathrm{H} & 4.31200000 & 15.17210000 & 17.64480000 \\ \mathrm{C} & 5.37870000 & 14.77400000 & 15.98980000 \\ \mathrm{C} & 6.65560000 & 14.69150000 & 15.49320000 \\ \mathrm{H} & 6.79280000 & 14.45340000 & 14.58340000 \\ \mathrm{C} & 2.10230000 & 14.64360000 & 14.73740000 \\ \mathrm{H} & 2.25950000 & 14.28810000 & 13.87090000 \\ \mathrm{C} & 0.79090000 & 15.04280000 & 15.12770000 \\ \mathrm{C} & 0.47580000 & 15.35950000 & 16.40840000 \\ \mathrm{H} & 1.13510000 & 15.31050000 & 17.09020000 \\ \mathrm{C} & -0.81860000 & 15.75610000 & 16.71240000 \\ \mathrm{H} & -1.06680000 & 15.95490000 & 17.60680000 \\ \mathrm{C} & -1.72510000 & 15.85190000 & 15.69910000 \\ \mathrm{H} & -2.61060000 & 16.12830000 & 15.90280000 \\ \mathrm{C} & -0.20340000 & 15.15460000 & 14.16260000 \\ \mathrm{H} & -0.00720000 & 14.92090000 & 13.26200000 \\ \mathrm{Br} & 2.37260000 & 16.83900000 & 12.32880000\end{array}$

$\begin{array}{crrr}3^{6+} .6 \mathrm{Cl}^{-}: & & \\ 41 & 1.08090000 & 10.69490000 & 21.32160000 \\ \mathrm{~N} & 3.56340000 & 10.56340000 & 18.05700000 \\ \mathrm{~N} & 4.42200000 & 10.50790000 & 17.03390000 \\ \mathrm{~N} & 4.92700000 & 9.80190000 & 16.88880000 \\ \mathrm{H} & 5.42030000 & 12.69270000 & 14.29750000 \\ \mathrm{~N} & 8.62560000 & 17.41170000 & 14.91720000 \\ \mathrm{~N} & 5.68610000 & 17.70820000 & 18.59790000 \\ \mathrm{~N} & 0.51160000 & 11.98670000 & 21.74930000 \\ \mathrm{C} & -0.22450000 & 11.82200000 & 22.39050000 \\ \mathrm{H} & 0.13150000 & 12.45180000 & 20.96240000 \\ \mathrm{H} & 0.78460000 & 9.58770000 & 22.01190000 \\ \mathrm{C} & 0.18850000 & 9.62840000 & 22.75050000 \\ \mathrm{H} & & & \end{array}$




\begin{tabular}{|c|c|c|c|}
\hline C & 1.34580000 & 8.40050000 & 21.64570000 \\
\hline $\mathrm{H}$ & 1.13660000 & 7.60990000 & 22.12920000 \\
\hline C & 2.22420000 & 8.34030000 & 20.56650000 \\
\hline $\mathrm{H}$ & 2.61280000 & 7.51400000 & 20.30440000 \\
\hline C & 2.52080000 & 9.50830000 & 19.88240000 \\
\hline C & 1.93090000 & 10.68060000 & 20.26080000 \\
\hline $\mathrm{H}$ & 2.11370000 & 11.48220000 & 19.78490000 \\
\hline C & 3.43460000 & 9.47480000 & 18.78880000 \\
\hline $\mathrm{H}$ & 3.93560000 & 8.69160000 & 18.59340000 \\
\hline C & 4.47360000 & 11.65090000 & 16.19530000 \\
\hline C & 3.68830000 & 12.76640000 & 16.39290000 \\
\hline $\mathrm{H}$ & 3.08010000 & 12.79950000 & 17.12190000 \\
\hline C & 3.79080000 & 13.83470000 & 15.52550000 \\
\hline $\mathrm{H}$ & 3.25100000 & 14.60520000 & 15.65790000 \\
\hline C & 4.66280000 & 13.78880000 & 14.48030000 \\
\hline $\mathrm{H}$ & 4.73550000 & 14.52550000 & 13.88490000 \\
\hline C & 5.34260000 & 11.63660000 & 15.10920000 \\
\hline $\mathrm{H}$ & 5.88250000 & 10.87240000 & 14.94480000 \\
\hline C & 6.41300000 & 12.67930000 & 13.17300000 \\
\hline $\mathrm{H}$ & 6.07910000 & 13.23160000 & 12.42220000 \\
\hline $\mathrm{H}$ & 6.53910000 & 11.75350000 & 12.84590000 \\
\hline C & 7.73260000 & 13.23390000 & 13.67490000 \\
\hline C & 8.64580000 & 12.37950000 & 14.26700000 \\
\hline $\mathrm{H}$ & 8.46340000 & 11.44820000 & 14.31050000 \\
\hline C & 9.82230000 & 12.87590000 & 14.79550000 \\
\hline C & 10.07610000 & 14.24970000 & 14.72700000 \\
\hline $\mathrm{H}$ & 10.87240000 & 14.60110000 & 15.10770000 \\
\hline C & 9.17830000 & 15.10000000 & 14.11030000 \\
\hline C & 8.00100000 & 14.57080000 & 13.58390000 \\
\hline $\mathrm{H}$ & 7.37770000 & 15.14650000 & 13.15670000 \\
\hline C & 9.46630000 & 16.55520000 & 14.01060000 \\
\hline $\mathrm{H}$ & 9.32100000 & 16.84460000 & 13.07510000 \\
\hline $\mathrm{H}$ & 10.42080000 & 16.70580000 & 14.22630000 \\
\hline C & 8.59940000 & 18.72210000 & 14.69430000 \\
\hline $\mathrm{H}$ & 9.08290000 & 19.08510000 & 13.96150000 \\
\hline C & 7.88440000 & 19.54950000 & 15.50890000 \\
\hline $\mathrm{H}$ & 7.88940000 & 20.48700000 & 15.35550000 \\
\hline C & 7.15290000 & 19.02580000 & 16.55680000 \\
\hline $\mathrm{H}$ & 6.65800000 & 19.59640000 & 17.13300000 \\
\hline C & 7.15260000 & 17.67580000 & 16.75070000 \\
\hline C & 7.92460000 & 16.85960000 & 15.91830000 \\
\hline $\mathrm{H}$ & 7.95220000 & 15.92080000 & 16.06080000 \\
\hline C & 6.40190000 & 16.99940000 & 17.74910000 \\
\hline $\mathrm{H}$ & 6.41580000 & 16.05110000 & 17.80370000 \\
\hline
\end{tabular}




\begin{tabular}{|c|c|c|c|}
\hline$N$ & 10.29130000 & 10.69490000 & 15.87410000 \\
\hline$N$ & 7.80890000 & 10.56340000 & 19.13870000 \\
\hline$N$ & 6.95020000 & 10.50790000 & 20.16180000 \\
\hline $\mathrm{H}$ & 6.44530000 & 9.80190000 & 20.30690000 \\
\hline $\mathrm{N}$ & 5.95190000 & 12.69270000 & 22.89820000 \\
\hline$N$ & 2.74670000 & 17.41170000 & 22.27850000 \\
\hline C & 10.86060000 & 11.98670000 & 15.44640000 \\
\hline $\mathrm{H}$ & 11.59680000 & 11.82200000 & 14.80520000 \\
\hline $\mathrm{H}$ & 11.24080000 & 12.45180000 & 16.23330000 \\
\hline C & 10.58760000 & 9.58770000 & 15.18380000 \\
\hline $\mathrm{H}$ & 11.18370000 & 9.62840000 & 14.44520000 \\
\hline C & 10.02640000 & 8.40050000 & 15.55000000 \\
\hline $\mathrm{H}$ & 10.23560000 & 7.60990000 & 15.06660000 \\
\hline C & 9.14800000 & 8.34030000 & 16.62920000 \\
\hline $\mathrm{H}$ & 8.75940000 & 7.51400000 & 16.89140000 \\
\hline C & 8.85140000 & 9.50830000 & 17.31340000 \\
\hline C & 9.44130000 & 10.68060000 & 16.93500000 \\
\hline $\mathrm{H}$ & 9.25860000 & 11.48220000 & 17.41090000 \\
\hline C & 7.93760000 & 9.47480000 & 18.40690000 \\
\hline $\mathrm{H}$ & 7.43660000 & 8.69160000 & 18.60230000 \\
\hline C & 6.89860000 & 11.65090000 & 21.00050000 \\
\hline C & 7.68390000 & 12.76640000 & 20.80280000 \\
\hline $\mathrm{H}$ & 8.29210000 & 12.79950000 & 20.07380000 \\
\hline C & 7.58140000 & 13.83470000 & 21.67020000 \\
\hline $\mathrm{H}$ & 8.12120000 & 14.60520000 & 21.53790000 \\
\hline C & 6.70940000 & 13.78880000 & 22.71540000 \\
\hline $\mathrm{H}$ & 6.63670000 & 14.52550000 & 23.31080000 \\
\hline C & 6.02960000 & 11.63660000 & 22.08660000 \\
\hline $\mathrm{H}$ & 5.48970000 & 10.87240000 & 22.25100000 \\
\hline C & 4.95930000 & 12.67930000 & 24.02270000 \\
\hline $\mathrm{H}$ & 5.29310000 & 13.23160000 & 24.77350000 \\
\hline $\mathrm{H}$ & 4.83310000 & 11.75350000 & 24.34980000 \\
\hline C & 3.63970000 & 13.23390000 & 23.52080000 \\
\hline C & 2.72640000 & 12.37950000 & 22.92870000 \\
\hline $\mathrm{H}$ & 2.90880000 & 11.44820000 & 22.88520000 \\
\hline C & 1.54990000 & 12.87590000 & 22.40030000 \\
\hline C & 1.29610000 & 14.24970000 & 22.46870000 \\
\hline $\mathrm{H}$ & 0.49980000 & 14.60110000 & 22.08800000 \\
\hline C & 2.19390000 & 15.10000000 & 23.08540000 \\
\hline C & 3.37120000 & 14.57080000 & 23.61190000 \\
\hline $\mathrm{H}$ & 3.99450000 & 15.14650000 & 24.03910000 \\
\hline C & 1.90590000 & 16.55520000 & 23.18510000 \\
\hline $\mathrm{H}$ & 2.05130000 & 16.84460000 & 24.12060000 \\
\hline $\mathrm{H}$ & 0.95150000 & 16.70580000 & 22.9695000 \\
\hline
\end{tabular}




$\begin{array}{lrrr}\mathrm{C} & 2.77280000 & 18.72210000 & 22.50140000 \\ \mathrm{H} & 2.28930000 & 19.08510000 & 23.23430000 \\ \mathrm{C} & 3.48780000 & 19.54950000 & 21.68690000 \\ \mathrm{H} & 3.48280000 & 20.48700000 & 21.84030000 \\ \mathrm{C} & 4.21930000 & 19.02580000 & 20.63890000 \\ \mathrm{H} & 4.71420000 & 19.59640000 & 20.06270000 \\ \mathrm{C} & 4.21960000 & 17.67580000 & 20.44500000 \\ \mathrm{C} & 3.44770000 & 16.85960000 & 21.27740000 \\ \mathrm{H} & 3.42000000 & 15.92080000 & 21.13490000 \\ \mathrm{C} & 4.97030000 & 16.99940000 & 19.44670000 \\ \mathrm{H} & 4.95640000 & 16.05110000 & 19.39200000 \\ \mathrm{~N} & 6.40190000 & 16.99940000 & 17.74910000 \\ \mathrm{H} & 6.41480000 & 16.12090000 & 17.79970000 \\ \mathrm{H} & 6.53910000 & 11.75350000 & 12.84590000 \\ \mathrm{H} & 8.46340000 & 11.44820000 & 14.31050000 \\ \mathrm{~N} & 4.42200000 & 10.50790000 & 17.03390000 \\ \mathrm{H} & 4.92700000 & 9.80190000 & 16.88880000 \\ \mathrm{H} & 5.88250000 & 10.87240000 & 14.94480000 \\ \mathrm{C} & 9.14800000 & 8.34030000 & 16.62920000 \\ \mathrm{C} & 10.02640000 & 8.40050000 & 15.55000000 \\ \mathrm{H} & 10.23560000 & 7.60990000 & 15.06660000 \\ \mathrm{Cl} & 4.34880000 & 13.75760000 & 19.73680000 \\ \mathrm{Cl} & 7.02340000 & 13.75760000 & 17.45890000 \\ \mathrm{H} & 4.95740000 & 16.12090000 & 19.39610000 \\ \mathrm{~N} & 5.68610000 & 17.70820000 & 18.59790000 \\ \mathrm{C} & 7.15290000 & 19.02580000 & 16.55680000 \\ \mathrm{H} & 6.65800000 & 19.59640000 & 17.13300000 \\ \mathrm{C} & 7.15260000 & 17.67580000 & 16.75070000 \\ \mathrm{C} & 7.92460000 & 16.85960000 & 15.91830000 \\ \mathrm{H} & 7.95220000 & 15.92080000 & 16.06080000 \\ \mathrm{H} & 6.41580000 & 16.05110000 & 17.80370000 \\ \mathrm{C} & 4.97030000 & 16.99940000 & 19.44670000 \\ \mathrm{H} & 4.95640000 & 16.05110000 & 19.39200000 \\ \mathrm{~N} & 4.97030000 & 16.99940000 & 19.44670000 \\ \mathrm{C} & & & \\ & 6.40190000 & 16.99940000 & 17.74910000\end{array}$




\section{References}

S1. A. Blanco-Gómez, Á. Fernández-Blanco, V. Blanco, J. Rodríguez, C. Peinador, M. D. García, J. Am. Chem. Soc. 2019, 141, 3959-3964.

S2. A. Blanco-Gómez, L. Neira, J. L. Barriada, M. Melle-Franco, C. Peinador, M. D. García, Chem. Sci. 2019, 10, 10680-10686.

S3. Dolomanov, O. V.; Bourhis, L. J.; Gildea, R. J.; Howard, J. A. K.; Puschmann, H. J. Appl. Cryst. 2009, 42, 339-341.

S4. Sheldrick, G. M. Acta Cryst. 2015, A71, 3-8.

S5. Sheldrick, G. M. Acta Cryst. 2015, C71, 3-8. 